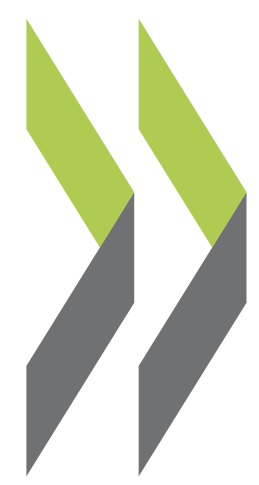

OECD Economics Department Working Papers No. 1699

The role of the Australian financial sector in supporting a sustainable and inclusive recovery
Christine Lewis, Ben Westmore 


\section{ECONOMICS DEPARTMENT}

\section{THE ROLE OF THE AUSTRALIAN FINANCIAL SECTOR IN SUPPORTING A SUSTAINABLE AND} INCLUSIVE RECOVERY

\section{ECONOMICS DEPARTMENT WORKING PAPERS No. 1699}

By Christine Lewis and Ben Westmore

OECD Working Papers should not be reported as representing the official views of the OECD or of its member countries. The opinions expressed and arguments employed are those of the author(s).

Authorised for publication by Álvaro Pereira, Director, Country Studies Branch, Economics Department.

All Economics Department Working Papers are available at www.oecd.org/eco/workingpapers.

JT03487575 
OECD Working Papers should not be reported as representing the official views of the OECD or of its member countries. The opinions expressed and arguments employed are those of the author(s).

Working Papers describe preliminary results or research in progress by the author(s) and are published to stimulate discussion on a broad range of issues on which the OECD works.

Comments on Working Papers are welcomed, and may be sent to the Economics Department, OECD, 2 rue André Pascal, 75775 Paris Cedex 16, France, or by e-mail to eco.contact@oecd.org.

All Economics Department Working Papers are available at www.oecd.org/eco/workingpapers.

This document and any map included herein are without prejudice to the status of or sovereignty over any territory, to the delimitation of international frontiers and boundaries and to the name of any territory, city or area.

The statistical data for Israel are supplied by and under the responsibility of the relevant Israeli authorities. The use of such data by the OECD is without prejudice to the status of the Golan Heights, East Jerusalem and Israeli settlements in the West Bank under the terms of international law.

(C) OECD (2021)

You can copy, download or print OECD content for your own use, and you can include excerpts from OECD publications, databases and multimedia products in your own documents, presentations, blogs, websites and teaching materials, provided that suitable acknowledgment of OECD as source and copyright owner is given. All requests for commercial use and translation rights should be submitted to PubRights@oecd.org. 


\title{
Abstract/Resumé \\ The role of the Australian financial sector in supporting a sustainable and inclusive recovery
}

\begin{abstract}
Australia's financial sector entered the COVID-19 crisis in a strong position, enabling it to play a key role in cushioning the pandemic's impact. Once the national economy reopens, policymakers will turn their focus to securing a robust, sustainable and inclusive recovery. However, low interest rates are boosting house prices and demand for credit in a banking sector that is already highly exposed to housing and highly indebted households. At the same time, many young and innovative firms - which are the drivers of job creation and productivity growth - struggle to access finance. And financial frictions impede the alignment of financial flows with environmental sustainability. Addressing these obstacles, through regulatory change, developing alternatives to bank finance and facilitating technological transformation, would raise productivity and set the recovery on a more sustainable path. Financial inclusion and financial literacy are comparatively high and financial education is entrenched at schools. Further efforts are still needed to address persistent gaps in outcomes for disadvantaged groups, accompanied by stronger consumer protections to ensure that the recovery is inclusive.
\end{abstract}

This Working Paper relates to the 2021 Economic Survey of Australia https://www.oecd.org/economy/australia-economic-snapshot/.

Key words: Australian financial system, household debt, access to finance, environmental risk exposure, financial inclusion.

JEL codes: G20, G21, G24, G28, G33, Q58.

\section{Le rôle du secteur financier australien dans le soutien d'une reprise durable et inclusive}

Le secteur financier australien est entré dans la crise du COVID-19 en position de force, lui permettant de jouer un rôle clé dans l'amortissement de l'impact de la pandémie. Une fois l'économie nationale rouverte, les décideurs politiques se concentreront sur une reprise solide, durable et inclusive. Cependant, la faiblesse des taux d'intérêt stimule les prix des logements et la demande de crédit dans un secteur bancaire déjà fortement exposé au logement et aux ménages très endettés. Dans le même temps, de nombreuses entreprises jeunes et innovantes - qui sont les moteurs de la création d'emplois et de la croissance de la productivité - ont du mal à accéder au financement. Et les frictions financières entravent l'alignement des flux financiers avec la durabilité environnementale. S'attaquer à ces obstacles, par le biais de changements réglementaires, en développant des alternatives au financement bancaire et en facilitant la transformation technologique, augmenterait la productivité et placerait la reprise sur une voie plus durable. L'inclusion financière et la littératie financière sont relativement élevées et l'éducation financière est ancrée dans les écoles. Des efforts supplémentaires sont encore nécessaires pour combler les écarts persistants dans les résultats pour les groupes défavorisés, accompagnés de protections renforcées des consommateurs pour garantir que la reprise est inclusive.

Ce document de travail a trait à l'Étude économique de l'OCDE de l'Australie, 2021 https://www.oecd.org/fr/economie/australie-en-un-coup-d-oeil/.

Mots clés: Système financier australien, dette des ménages, accès au financement, exposition aux risques environnementaux, inclusion financière.

Codes: G20, G21, G24, G28, G33, Q58. 


\section{Table of contents}

\section{The role of the Australian financial sector in supporting a sustainable and inclusive} recovery

Key trends in Australia's financial sector

The financial sector has played a critical role in the COVID-19 crisis response

Shoring up liquidity

Flattening the insolvencies curve

Maintaining financial stability

Channelling finance to viable and productive firms

Improving access to credit

Broadening sources of finance beyond banks

$\begin{array}{ll}\text { Supporting the green transition } & 39\end{array}$

$\begin{array}{ll}\text { Enhancing risk disclosure } & 40\end{array}$

Funding the green transition

Maintaining well-functioning insurance markets amid more frequent climate-related natural disasters

Strengthening households' resilience and mitigating inequality 46

Ensuring consumer credit protection is appropriate $\quad 46$

$\begin{array}{ll}\text { Narrowing gaps in financial literacy and inclusion } & 49\end{array}$

References

Annex A. The Royal Commission into misconduct in the financial services industry 63

\section{Tables}

Table 1. Most superannuation assets are managed by industry funds

Table 2. Timeline of inquiries into the financial services industry 10

Table 3. Overview of policies in response to COVID-19 relying on the financial sector 11

Table 4. The authorities have used a range of policies to reduce financial stability risks 22

Table 5. Risk weights are high for SME loans unless secured by residential property 26

Table 6. Examples of government venture capital initiatives

Table 7. Recommendations to ensure the financial sector supports a sustainable and inclusive recovery $\quad 54$

Annex Table A.1. Recommendations from the royal commission relating to the banking sector 63

\section{Figures}

Figure 1. Australia's financial system has grown dramatically in recent decades 4

Figure 2. Around half of superannuation funds' assets are invested in equities 8

Figure 3. The banking system is relatively concentrated 9

Figure 4. Institutions in the Australian financial sector and their responsibilities $\quad 10$

Figure 5. Stronger capital ratios supported banks' resilience 11

Figure 6. The Term Funding Facility provided a large amount of low-cost funding for banks 14 
Figure 7. Most deferrals from the initial phase unwound at an orderly pace 15

Figure 8. There have been far fewer business insolvencies than usual 16

Figure 9. Australia's insolvency laws have become more friendly to entrepreneurship 17

Figure 10. Banks are well capitalised and asset quality has only deteriorated modestly 19

Figure 11. Household debt and bank exposures to real estate are high 20

Figure 12. Macroprudential policies could be tightened further 22

Figure 13. Access to finance is a barrier for innovative firms and innovation 24

Figure 14. Obtaining finance has become more difficult $\quad 24$

Figure 15. Lending is highly skewed towards households $\quad 25$

Figure 16. The interest rate spread on SME loans is relatively wide $\quad 26$

Figure 17. The major banks have remained entrenched 27

Figure 18. Open banking is being phased in $\quad 32$

Figure 19. The stock market is sizeable and liquid $\quad 34$

Figure 20. Public equity raising has been comparatively strong $\quad 34$

Figure 21. Small IPOs are relatively common $\quad 36$

Figure 22. Venture capital is low and has not recovered since the global financial crisis 37

Figure 23. Alternative finance is still in its infancy $\quad 39$

$\begin{array}{ll}\text { Figure 24. Green bonds have grown rapidly } & 44\end{array}$

Figure 25. Overall levels of financial knowledge and inclusion compare well $\quad 49$

Figure 26. Financial knowledge is strongly related to demographic characteristics 50

Figure 27. Financial literacy is a little above the OECD average with wide dispersion 51

Figure 28. Financial inclusion, knowledge and resilience are lower for Indigenous Australians 52

\section{Boxes}

$\begin{array}{ll}\text { Box 1. Australia's superannuation industry } & 7\end{array}$

Box 2. Overview of changes to Australia's insolvency laws 16

Box 3. Lessons from the UK experience of reducing barriers to entry in the banking sector 28

Box 4. Australia's Consumer Data Right and open banking 31

Box 5. The Task Force on Climate-related Financial Disclosures $\quad 42$

Box 6. The EU climate benchmarks $\quad 45$

Box 7. Measuring financial literacy in Australia $\quad 54$ 


\title{
The role of the Australian financial sector in supporting a sustainable and inclusive
} recovery

\author{
By Christine Lewis and Ben Westmore ${ }^{1}$
}

Australia's well-developed financial sector is a vital part of the economy. Its direct contribution is amongst the highest in the OECD, at around $9 \%$ of gross value added. The global financial crisis highlighted the potential for an insufficiently supervised financial sector to harm growth and put the economy under stress. Credit over-expansion can weigh on growth and increase inequality (Cournède et al., 2015). However, the COVID-19 crisis has demonstrated that a well-capitalised and well-regulated financial sector can cushion, rather than amplify, economic shocks, both in Australia and elsewhere (RBA, 2020a). And, in normal times, the financial sector contributes to productivity growth by allocating financial resources across the economy efficiently and raises wellbeing by facilitating transactions and saving.

Against this backdrop - and the fact that the COVID-19 pandemic brought the first recession Australia has seen in 28 years - this Working Paper explores ways that various parts of the financial sector can contribute to a stronger, more sustainable and inclusive recovery. After highlighting key features of Australia's financial sector, it considers the response to the pandemic and the implications for financial stability. It then examines three ways that policymakers can ensure the financial sector contributes to the recovery: (i) by enhancing mechanisms that channel funds to productive firms, particularly young and innovative firms; (ii) by addressing financial frictions impeding the transition to a low-emissions economy; and (iii) by equipping individuals with sufficient financial knowledge and regulatory protections. The main focus is on the banking sector, given its centrality in the financial system, and investors, including pension funds. Other ways that the financial system could contribute to the recovery that are not evaluated here include through deeper debt and derivatives markets, better-functioning insurance markets and a more efficient pension system. Overall, this Working Paper highlights that:

- The strength of the Australian financial system allowed it to support the economy during the crisis. While near-term risks to financial stability may be manageable, pre-existing medium-term risks stemming from high housing debt remain.

- Technological developments and regulatory change could lower barriers to credit for young and innovative firms by improving competition in lending and allowing better assessment of credit risk.

- Disclosure of climate-related financial risks has progressed substantially in recent years, but a lack of information continues to hamper the efficient allocation of funds.

\footnotetext{
${ }^{1}$ Christine Lewis was a consultant to the OECD Economics Department at the time this paper was written. Ben Westmore is the Head of the Australia Desk in the OECD Economics Department. The paper benefitted from helpful comments on earlier drafts from numerous OECD colleagues, particularly Laurence Boone, Patrick Lenain, Isabell Koske, Alvaro Pereira, Dennis Dlugosch, Muge Adalet McGowan, Bert Brys, David Bradbury, Rob Patalano, Catriona Marshall, Chiara Monticone, Anna Dawson, Caroline Roulet, Serdar Celik, Miles Larbey, Leigh Wolfrom, Mamiko Yokoi-Arai and lota Nassr. The paper also benefitted from comments by experts in Australia and by members of the OECD Economic and Development Review Committee. The authors would especially like to thank Damien Azzopardi and Mauricio Hitschfeld for statistical assistance and Karima Diallo and Stephanie Henry for editorial assistance.
} 
- Levels of financial literacy and inclusion are high overall but greater efforts to focus on disadvantaged groups and closing gaps in consumer protections would increase inclusion.

\section{Key trends in Australia's financial sector}

Australia's financial system, as measured by its assets, has grown much faster than the overall economy over recent decades. By 2020, assets held by financial institutions were approaching $500 \%$ of GDP on an unconsolidated basis, up from $200 \%$ in the 1990s (Figure 1, Panel A). On a consolidated basis, and excluding central bank assets, financial institutions' assets totalled 333\% of GDP in 2020, above the median of around $250 \%$ among OECD countries with consolidated data (Figure 1, Panel B). Following financial deregulation and the establishment of a compulsory defined-contribution pension system (known as "superannuation") in the 1990s, banks and pension funds have come to dominate the sector (Figure 1, Panel A; Box 1).

Australia's financial institutions devote a larger share of their balance sheet to household debt than those in other OECD countries. Businesses are, in aggregate, less leveraged than other countries and their debtto-GDP ratio is below the OECD median, partly reflecting the system of "dividend imputation" (whereby a domestic investor ultimately only pays tax on distributed corporate profits at their personal income tax rate, removing double taxation) which provides neutral tax treatment of debt and equity investment.

\section{Figure 1. Australia's financial system has grown dramatically in recent decades}
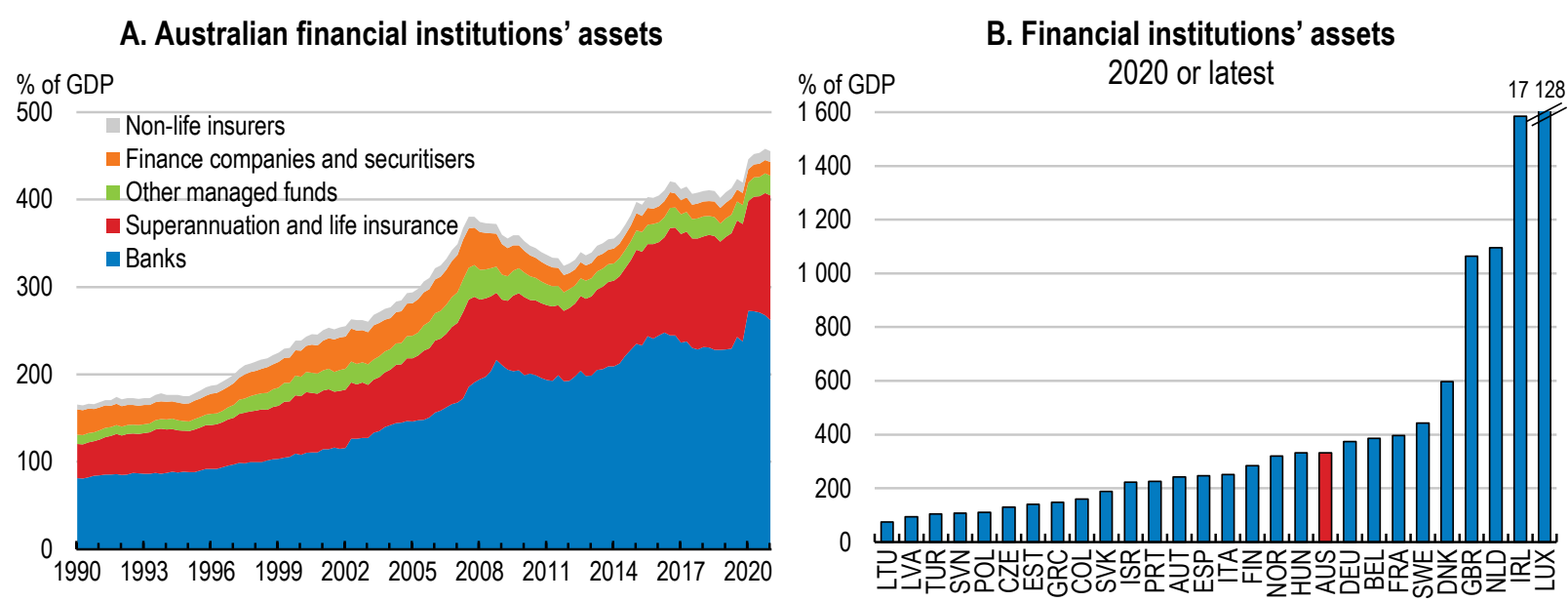

Note: In panel A data are not consolidated and there is a break in July 2019 due to changes in reporting. Panel B shows assets on a consolidated basis for countries with available data and excludes central bank assets, with the exception of the United Kingdom and the Slovak Republic. Source: ABS; OECD, National Accounts database; OECD Economic Outlook Database; and RBA.

StatLink त्ञाजा https://stat.link/ke2qyg

\section{Box 1. Australia's superannuation industry}

Australia's mandatory retirement saving system - known as superannuation - was created in 1992 to increase retirement savings, thereby reducing reliance on the old-age pension and associated fiscal pressures. At inception, the compulsory contribution rate was $3 \%$ of the employees' income (4\% for large employers). This rate has increased to $10 \%$ currently and is legislated to gradually rise to $12 \%$ by July 2025. There are tax incentives for employees to make additional voluntary contributions. 
Initially, employers selected the fund where contributions were paid. In 1999 "self-managed superannuation funds" were created to allow small businesses and self-employed workers to manage their superannuation. Since 2005 employees have been able to choose the fund where their contribution is paid. "Industry funds", which are run on a not-for-profit basis, are the largest type of fund with $28 \%$ of assets under management and $46 \%$ of accounts (Table 1). A further quarter of assets are held by selfmanaged superannuation funds", whereby an individual manages their own funds with up to three family or friends. Retail funds, run by financial institutions on a for-profit basis, account for around one-fifth of assets.

Table 1. Most superannuation assets are managed by industry funds

\begin{tabular}{l|r|r|r}
\hline \multicolumn{1}{c|}{ Type of fund } & \multicolumn{1}{|c|}{$\begin{array}{c}\text { Total assets } \\
\text { (AUD billion) }\end{array}$} & Number of funds & \multicolumn{1}{c}{$\begin{array}{c}\text { Number of accounts } \\
\text { (million) }\end{array}$} \\
\hline Industry & 927 & 33 & 11.3 \\
\hline Self-managed funds & 822 & 599593 & 1.1 \\
\hline Retail & 689 & 93 & 8.1 \\
\hline Public sector & 584 & 16 & 3.5 \\
\hline Corporate & 61 & 14 & 0.3 \\
\hline Total & 3303 & & 24.4 \\
\hline
\end{tabular}

Note: Data are for June 2021 except number of accounts which is at June 2020. The value of assets does not sum to the total. Source: APRA; Association of Superannuation Funds of Australia (2021), Superannuation Statistics: March 2021

The system of superannuation has contributed substantially to Australia's national saving, with assets of AUD3 trillion - around $160 \%$ of GDP - by June 2021. In 2019, Australia had the fourth-largest pool of pension fund assets in the OECD in absolute terms. The value of superannuation assets is expected to continue outpacing GDP growth over the next two decades given the rising contribution rate to 2025 and investment returns on existing balances (Deloitte, 2019).

Superannuation funds have diversified portfolios overall (Figure 2). Prudentially regulated superannuation funds have invested about half of all assets in equities. Self-managed funds have lower equity holdings on average ( $30 \%$ of total) and are more heavily invested in property (16\% of assets). Together these funds held around 30\% of the Australian Stock Exchange at end 2020.

Figure 2. Around half of superannuation funds' assets are invested in equities

At June 2021

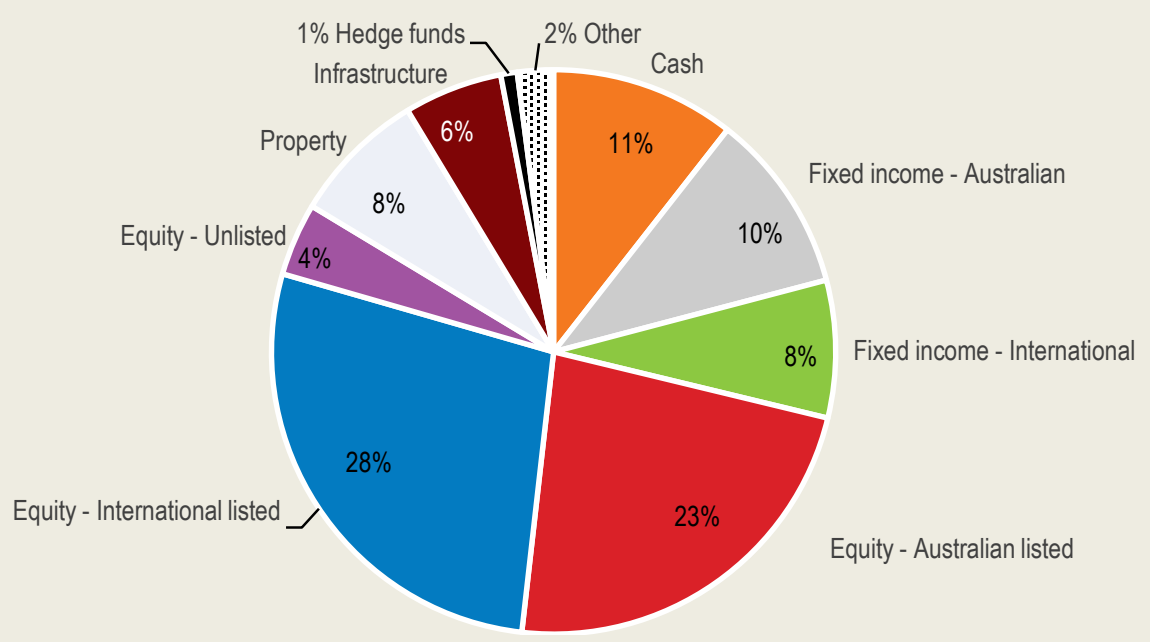


Note: Data are for APRA-regulated funds with more than four members which accounted for $69 \%$ of superannuation fund assets. Source: APRA (2021), Quarterly Superannuation Performance Statistics.

Box source: ASFA; APRA; ATO.

StatLink त्गाड़L https://stat.link/m3czku

Banks account for over half of financial system assets. More than many other OECD countries, the level of, and growth in, bank assets reflects expanding household debt, which grew from around $50 \%$ of GDP in the mid-1990s to $120 \%$ of GDP in 2020 . These assets are funded predominantly by households and foreign investors ( $30 \%$ each). Although banks reduced their reliance on foreign wholesale funding after the financial crisis, it is still considered a source of vulnerability (IMF, 2019). Another feature of Australia's banking landscape is the dominance of four major banks, which hold $80 \%$ of banking sector loans. Consequently, the sector is more concentrated than in the average OECD country (Figure 3 ). A "four pillars policy" prevents mergers between the four largest banks, aiming to preserve competition.

\section{Figure 3. The banking system is relatively concentrated}

Five-largest banks' share of assets, 2017

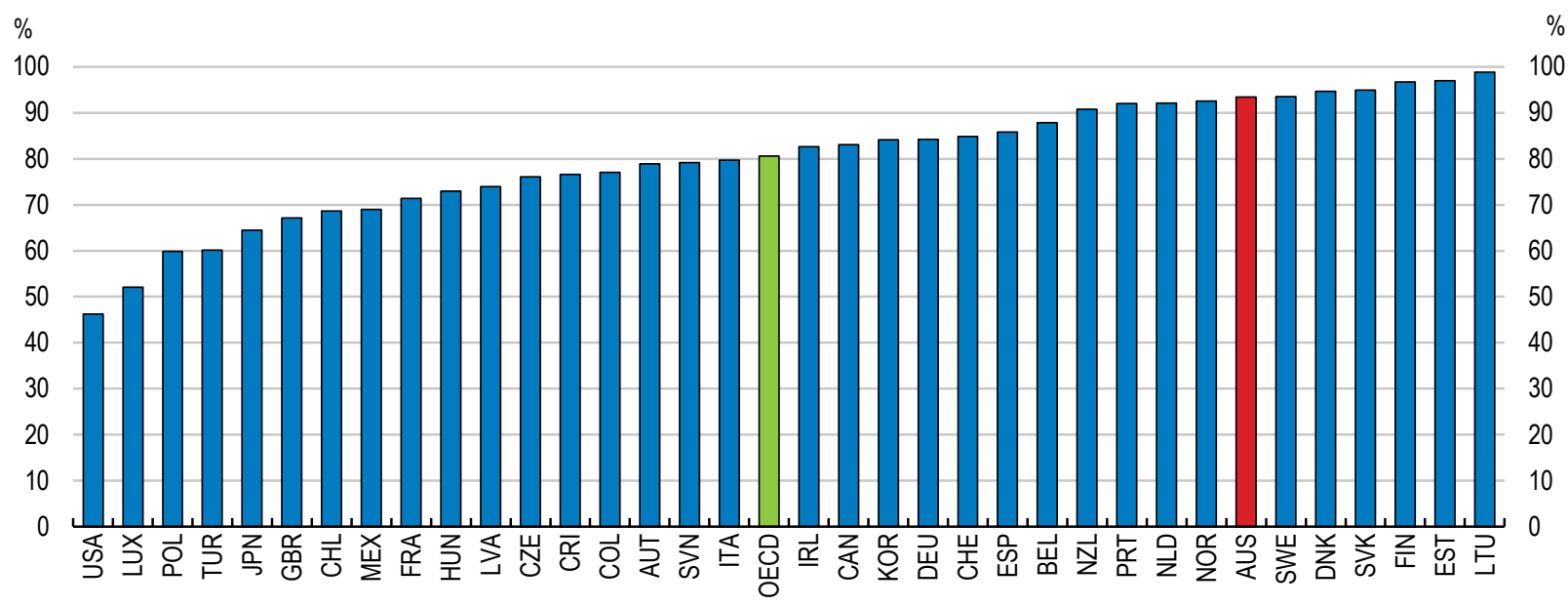

Source: World Bank Global Financial Development database.

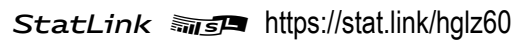

In recent years financial institutions, especially banks, have faced increased regulatory scrutiny. Financial institutions - including banks, superannuation funds, other managed funds, infrastructure operators and insurers - are regulated under the "twin peaks" model, with the Australian Prudential Regulation Authority (APRA) as the prudential supervisor and the Australian Securities and Investments Commission (ASIC) responsible for market conduct and consumer protection. Together with the Reserve Bank of Australia (RBA) - tasked with maintaining system stability - and the Australian Treasury, these regulators form the Council of Financial Regulators (Figure 4). Since a major independent inquiry into the financial system in 2013 and 2014 - the Financial System Inquiry - regulators have been increasingly active conducting inquiries and reviews into competition and conduct within the financial sector (Table 2). These culminated in a royal commission into misconduct in the sector, including banking, insurance, financial advice and superannuation (Annex A). A rate-rigging scandal and breaches of anti-money laundering laws led to reputational damage and fines exceeding AUD2 billion (EUR1.2 billion). These specific challenges came as the financial sector grappled with structural challenges including: the prospect of a prolonged period of low interest rates; the digital transformation of financial services with the potential for disintermediation and 
competition from fintech (financial technology) entrants (OECD, 2020a); and climate change-related risks and opportunities.

Figure 4. Institutions in the Australian financial sector and their responsibilities

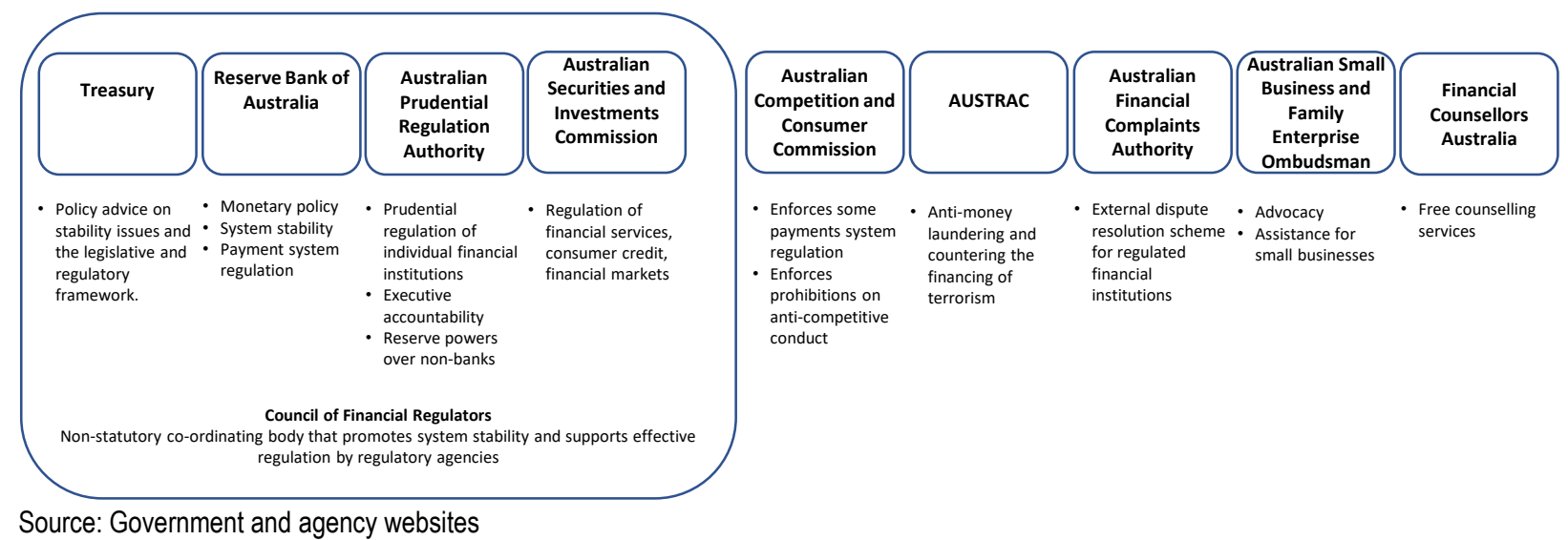

StatLink הत्ञाs https://stat.link/pr3e1t

Table 2. Timeline of inquiries into the financial services industry

\begin{tabular}{l|l}
\hline Date of final report & \multicolumn{1}{c}{ Inquiry or review } \\
\hline December 2014 & Financial System Inquiry \\
\hline September 2016 & ASIC Review of interest-only home loans: mortgage brokers' inquiries into consumers' requirements and objectives \\
\hline April 2017 & Retail Banking Remuneration Review (independent review commissioned by the Australian Bankers' Association) \\
\hline December 2017 & ASIC Enforcement Review (included corporate and financial sector misconduct) \\
\hline May 2018 & APRA Prudential Inquiry into the Commonwealth Bank of Australia \\
\hline August 2018 & Productivity Commission Competition in the Australian Financial System Inquiry \\
\hline December 2018 & ACCC Residential Mortgage Products inquiry \\
\hline February 2019 & Royal Commission into Misconduct in the Banking, Superannuation and Financial Services Industry \\
\hline February 2019 & Senate inquiry into credit and financial products targeted at Australians at risk of financial hardship \\
\hline July 2019 & APRA Capability Review \\
\hline December 2020 & ACCC Home Loans Price Inquiry \\
\hline Ongoing & Standing Committee on Economics Review of Australia's Four Major Banks and other Financial Institutions \\
\hline Ongoing & Senate Select Committee on Financial Technology and Regulatory Technology \\
\hline
\end{tabular}

\section{The financial sector has played a critical role in the COVID-19 crisis response}

From the outset of the pandemic, the financial sector has played an active role. One of the earliest announcements was by the banking sector, offering loan repayment deferrals to households and small and medium-sized businesses (SMEs). This was particularly important given households' high level of mortgage debt. In tandem, APRA provided regulatory relief by allowing banks (including credit unions and building societies) to exclude such deferrals from arrears for reporting purposes and by relaxing the supplementary capital requirements in force from January 2020 (known as "unquestionably strong" benchmarks, equivalent to around 2 percentage points of Common Equity Tier 1 capital ratios for major banks) (RBA, 2020a). Overall, APRA's guidance created a capital buffer equivalent to over 6 percentage points, one of the highest across comparable advanced economies (IMF, 2020a). A raft of government policies ensured there was plenty of liquidity for firms and households including by supporting the flow of credit (Table 3). This response was accompanied by looser monetary policy, a wage subsidy equivalent to $4 \frac{1}{2} \%$ of GDP, a temporary doubling of unemployment benefits and a temporary loosening of insolvency regulations. Together these cushioned the impact of the pandemic. 
Key to this response was the strengthening of the financial sector ahead of the crisis. Regulatory changes introduced since the global financial crisis and 2014 Financial System Inquiry had raised capital and liquidity ratios. The capital adequacy ratio for Australian banks was around $18 \%$ in June 2021 compared with $10 \%$ ahead of the global financial crisis (where "banks" is used broadly to include credit unions and building societies; Figure 5, Panel A). On an internationally comparable (less conservative) basis, the major banks' Tier 1 capital ratios are estimated to be within the top quartile of large banks internationally (RBA, 2021, 2020b). Stress tests of banks by APRA and the RBA also suggest that banks could withstand an adverse scenario; the APRA tests included a $30 \%$ fall in house prices and unemployment rising to $13 \%$ (Kearns, 2020; APRA 2020a). Financial markets perceive the sector to be in a good position with banks' equity prices recovering by late 2020 and subsequently outperforming the broader index (Figure 5, Panel B).

Figure 5. Stronger capital ratios supported banks' resilience

\section{A. Capital ratios}

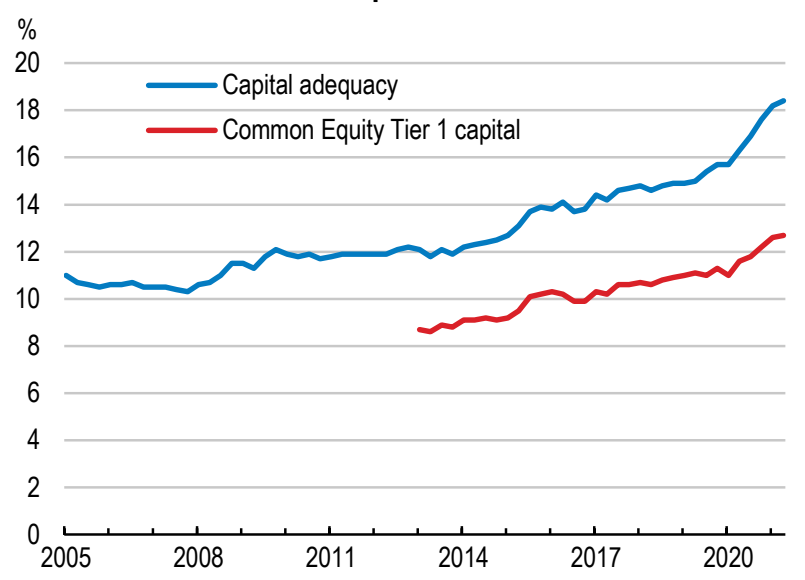

B. Equity prices, total return index

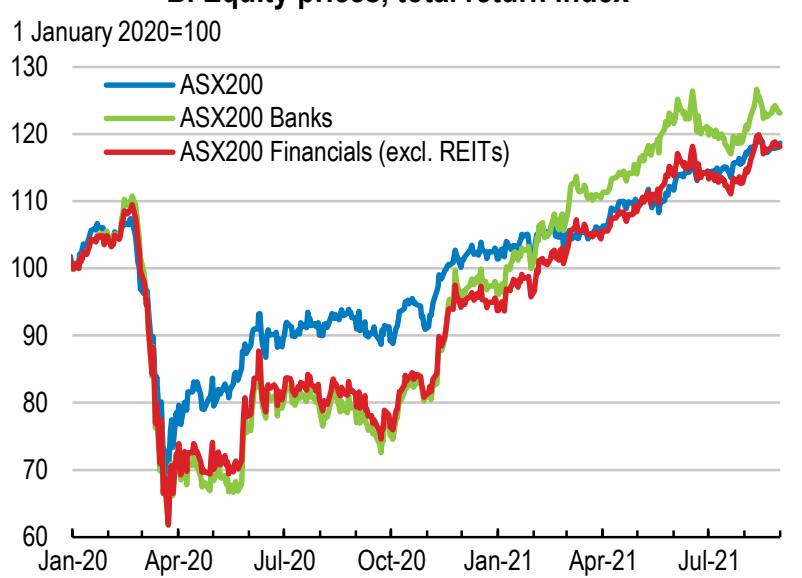

Note: In Panel A, data are for all authorised deposit-taking institutions as they are all regulated as banks. In Panel B ASX200 Financials excludes Real Estate Investment Trusts.

Source: APRA; Refinitiv.

StatLink त्गाडs https://stat.link/pq6n5d

Table 3. Overview of policies in response to COVID-19 relying on the financial sector

\begin{tabular}{|c|c|c|c|}
\hline Measure & Description & Timeframe & Take-up \\
\hline \multicolumn{4}{|c|}{ Policies instigated by the financial sector } \\
\hline Loan repayment holidays & $\begin{array}{l}\text { Banks deferred loan repayments for households } \\
\text { and SMEs affected by the crisis. Borrowers could } \\
\text { lengthen the loan tenure or restructure the } \\
\text { repayments. APRA also provided temporary } \\
\text { concessional capital treatment for deferred bank } \\
\text { loans. }\end{array}$ & $\begin{array}{l}\text { From late March } 2020 \text { for } \\
\text { six months. } \\
\text { Extended to March } 2021 \\
\text { at lenders' discretion. } \\
\text { Re-started in July } 2021 \\
\text { for three months. }\end{array}$ & $\begin{array}{l}\text { Peaked at } 10 \% \text { of loans and } \\
\text { AUD266 billion in May } 2020\end{array}$ \\
\hline $\begin{array}{l}\text { Temporary emergency } \\
\text { capital raising measures } \\
\text { for listed companies }\end{array}$ & $\begin{array}{l}\text { The ASX raised placement capacity from } 15 \% \text { to } \\
25 \% \text {. It also waived the one-for-one cap on non- } \\
\text { renounceable entitlement offers. }\end{array}$ & $\begin{array}{l}\text { From } 31 \text { March - } 31 \text { July } \\
\text { 2020. Extended to } 20 \\
\text { November } 2020 .\end{array}$ & \\
\hline $\begin{array}{l}\text { Co-ordinated support for } \\
\text { insurance policyholders }\end{array}$ & $\begin{array}{l}\text { General insurers received permission from the } \\
\text { competition authority to co-ordinate responses } \\
\text { including premium payment deferrals and coverage } \\
\text { of unoccupied premises. Life insurers received } \\
\text { permission to not consider potential exposure to } \\
\text { COVID-19 for frontline workers. }\end{array}$ & & \\
\hline
\end{tabular}




\begin{tabular}{|c|c|c|c|}
\hline \multicolumn{4}{|c|}{ Policies to support the flow of credit } \\
\hline $\begin{array}{l}\text { RBA Term Funding } \\
\text { Facility }\end{array}$ & $\begin{array}{l}\text { Initially banks could borrow up to } 3 \% \text { of total credit } \\
\text { outstanding for three years at } 0.25 \% \text {. } \\
\text { In the supplemental phase a further allowance was } \\
\text { made equivalent to } 2 \% \text { of credit outstanding was } \\
\text { available and from November } 2020 \text { banks could } \\
\text { borrow at } 0.1 \% \text {. } \\
\text { If banks lent to businesses, they could access } \\
\text { additional funding, with a higher multiple for SME } \\
\text { lending. }\end{array}$ & $\begin{array}{l}\text { Initial phase: } 30 \text { March - } \\
30 \text { September } 2020 \\
\text { Extended to June } 2021 .\end{array}$ & $\begin{array}{l}\text { A total of AUD213 billion was } \\
\text { available, with AUD188 billion } \\
\text { drawn down at end June } \\
2021 .\end{array}$ \\
\hline $\begin{array}{l}\text { Structured Finance } \\
\text { Support Fund }\end{array}$ & $\begin{array}{l}\text { The Australian Office of Financial Management is } \\
\text { making targeted investments in structured finance } \\
\text { markets used by smaller lenders that provide } \\
\text { consumer and business finance, investing in rated } \\
\text { term securitisations and in rated and unrated } \\
\text { securitisation warehouses. }\end{array}$ & From 25 March 2020 & $\begin{array}{l}\text { As at } 30 \text { June } 2021 \text {, } \\
\text { AUD3.8 billion in investments } \\
\text { had been committed. }\end{array}$ \\
\hline SME Guarantee Scheme & $\begin{array}{l}\text { Phase 1: Guarantee of up to } 50 \% \text { for unsecured } \\
\text { working capital loans for three years and up to } \\
\text { AUD250 } 000 \text {. } \\
\text { Phase 2: Loans can be secured, up to } \\
\text { AUD1 million and up to } 5 \text { years. The interest rate } \\
\text { was capped at } 10 \% \text {. } \\
\text { SME Recovery Loan Scheme:borrow up to } \\
\text { AUD5 million for up to } 10 \text { years, loan guarantee of } \\
80 \% \text {. Initially for SMEs that had received } \\
\text { JobKeeper in Q1 } 2021 \text { or had been adversely } \\
\text { affected by the floods in New South Wales in } \\
\text { March } 2021 \text {. Broader eligibility was announced in } \\
\text { August 2021. }\end{array}$ & $\begin{array}{l}\text { First phase: } 1 \text { April - } 30 \\
\text { September } 2020 \\
\text { Second phase: } 1 \text { October } \\
2020 \text { - } 30 \text { June } 2021 \\
\text { Third phase (also known } \\
\text { as the SME Recovery } \\
\text { Loan Scheme): } 1 \text { April } \\
2021 \text { - } 31 \text { December } \\
2021\end{array}$ & $\begin{array}{l}\text { As at } 30 \text { April } 2021 \text {, around } \\
54,000 \text { loans worth } \\
\text { approximately AUD } 4.7 \text { billion } \\
\text { had been made under the two } \\
\text { phases of the SME } \\
\text { Guarantee Scheme }\end{array}$ \\
\hline $\begin{array}{l}\text { Show Starter Loans } \\
\text { Scheme }\end{array}$ & $\begin{array}{l}100 \% \text { guarantee on loans for eligible arts and } \\
\text { entertainment businesses for up to half of the cost } \\
\text { of a new production or event. Administered under } \\
\text { the SME Guarantee Scheme }\end{array}$ & $\begin{array}{l}\text { December } 2020 \text { - } 30 \text { June } \\
2021\end{array}$ & $\begin{array}{l}\text { As at } 30 \text { April } 2021 \text {, four } \\
\text { loans worth AUD } 7.75 \text { million } \\
\text { had been written under the } \\
\text { Scheme. }\end{array}$ \\
\hline \multicolumn{4}{|c|}{ Other policies to support household and business finances through the financial sector } \\
\hline $\begin{array}{l}\text { Early access to } \\
\text { superannuation }\end{array}$ & $\begin{array}{l}\text { Access to AUD10 } 000 \text { before } 1 \text { July } 2020 \text { and } \\
\text { another AUD10 } 000 \text { from } 1 \text { July to } 31 \text { December } \\
2020 \text {. }\end{array}$ & $\begin{array}{l}20 \text { April-31 December } \\
2020\end{array}$ & $\begin{array}{l}4.9 \text { million applications } \\
\text { totalling AUD37.3 billion. }\end{array}$ \\
\hline Insolvency law & $\begin{array}{l}\text { Increased protection for Directors from risks of } \\
\text { personal liability for insolvent trading. } \\
\text { Minimum amount of debt that can trigger } \\
\text { insolvency actions by creditors raised to } \\
\text { AUD20 } 000 \text { (from AUD5 } 000 \text { for individuals and } \\
\text { AUD2 } 000 \text { for corporate insolvency). } \\
\text { Individuals have } 6 \text { months to respond to a } \\
\text { Bankruptcy Notice (from } 21 \text { days). } \\
\text { Companies have } 6 \text { months to respond to notices by } \\
\text { creditors (from } 21 \text { days). }\end{array}$ & $\begin{array}{l}\text { March 2020-September } \\
\text { 2020. Extended to } 31 \\
\text { December } 2020 \text {. }\end{array}$ & \\
\hline \multicolumn{4}{|c|}{ Other policies announced by APRA and ASIC } \\
\hline $\begin{array}{l}\text { Bank capital requirements } \\
\text { relaxed }\end{array}$ & $\begin{array}{l}\text { APRA relaxed "unquestionably strong" capital } \\
\text { requirement of common equity tier } 1 \text { ratio ( } 10.5 \% \\
\text { for major banks) and advised them to use } \\
\text { management capital buffers if needed. }\end{array}$ & $\begin{array}{l}19 \text { March } 2020 \text { until at } \\
\text { least December } 2021\end{array}$ & \\
\hline $\begin{array}{l}\text { Regulatory exemptions for } \\
\text { lenders }\end{array}$ & $\begin{array}{l}\text { All SME lending exempted from responsible } \\
\text { lending obligations (usually loans must be wholly or } \\
\text { predominantly for business purposes to be } \\
\text { exempt). }\end{array}$ & 20 March 2020-present & \\
\hline Asset revaluation deferred & $\begin{array}{l}\text { Annual revaluation of commercial properties used } \\
\text { as collateral was deferred. }\end{array}$ & $\begin{array}{l}24 \text { July } 2020 \text { - } 31 \text { March } \\
2021\end{array}$ & \\
\hline Dividends reduced & $\begin{array}{l}\text { Banks were to retain at least half their earnings and } \\
\text { make use of dividend reinvestment plans and other } \\
\text { capital management techniques. }\end{array}$ & $\begin{array}{l}19 \text { March - } 31 \text { December } \\
2020\end{array}$ & \\
\hline
\end{tabular}




\begin{tabular}{l|l|l|l}
\hline $\begin{array}{l}\text { Regulatory relief for "low } \\
\text { doc" capital raising }\end{array}$ & $\begin{array}{l}\text { ASIC expanded access to "low doc" capital raising } \\
\text { for companies that were suspended for 10 days } \\
\text { (from 5 days) in the past 12 months. }\end{array}$ & $\begin{array}{l}31 \text { March - 31 December } \\
2020\end{array}$ & \\
\hline
\end{tabular}

Note: This is not an exhaustive list but indicates the range of policies and announcements.

Source: Lewis and Liu (2020), "The COVID-19 outbreak and access to small business finance", RBA Bulletin, September; OECD (2020), COVID19 Government Financing Support Programmes for Businesses, www.oecd.org/finance/COVID-19-Government-Financing-SupportProgrammes-for-Businesses.pdf; OECD (2020), Insurance Sector Responses to COVID-19 by Governments, Supervisors and Industry, www.oecd.org/finance/insurance/Insurance-sector-responses-to-COVID-19-by-governments-supervisors-and-industry.pdf; $\quad$ RBA (2020a), Financial Stability Review, October; Government websites; Australian authorities.

\section{Shoring up liquidity}

Several schemes were put in place to ensure that credit continued to flow to businesses. These schemes were targeted at different parts of the lending market:

- A Term Funding Facility at the Reserve Bank of Australia - With funding of around AUD200 billion (approximately $10 \%$ of GDP), the facility aimed to provide banks with ample threeyear funding. When the scheme commenced, entitlements were based on credit outstanding in the three months to January 2020. Additional entitlements were also provided based on new lending to businesses since around the start of the scheme. SME lending was incentivised by offering an additional five dollars for each dollar of new lending; lending for large business was matched.

- A Structured Finance Support Fund - With funding of AUD15 billion designed to support banks and non-bank lenders that could not access the Term Funding Facility. The fund was used by the Australian Office of Financial Management to invest in structured finance markets. A forbearance special purpose vehicle was established to mitigate the impacts on securitisation vehicles of forbearance arrangements arising from COVID-19 hardship. To broaden access for smaller lenders without existing securitisation programmes, the Australian Office of Financial Management also invested in private warehousing facilities.

- A loan guarantee for SMEs - With a government guarantee of $50 \%$ on up to AUD40 billion in new lending to SMEs by participating lenders. The design of the scheme evolved from unsecured loans aimed at providing working capital, to larger loans for five years for investment, to a larger guarantee $(80 \%)$ with a longer and more flexible repayment period for qualifying firms that were particularly hard-hit by the pandemic.

Overall, these programmes appear to have helped maintain liquidity and support access to finance, although evaluation is hampered by limited publicly available data. The Term Funding Facility allowed banks to avoid fundraising in volatile bond markets (Figure 6). It supported some new business lending, indicated by the additional allowances, but little SME lending as loan demand was reportedly soft. It boosted housing lending activity, including refinancing. Fixed mortgage rates fell by more than variable rates and fixed-rate loans rose to $25 \%$ of outstanding housing loans (from 20\%) (Garner and Suthakar, 2021; Alston et al., 2020). However, because the initial and supplementary allowances under the facility were linked to credit outstanding, it could have disadvantaged new and growing banks. And by requiring high-quality collateral (for repurchase agreements with the RBA) the scheme may have favoured banks with self-securitised assets to use as collateral. Take-up of the loan guarantee for SMEs was lower than anticipated, even with its relatively small size, equivalent to $1 \%$ of GDP compared to $17 \%$ in the United Kingdom or $34 \%$ in Italy (IMF, 2020a). This reflected a combination of tighter lending standards (Kent, 2021), weak loan demand (in part due to adequate support through other government schemes) and financial institutions using their existing products and services to provide assistance. Overall, the three schemes have contained borrowing rates (ibid.). As well as evaluating the efficacy of each measure, policymakers should assess the subsequent effect of the guarantee on firm-level investment given evidence that high debt burdens can weigh on investment (Demmou et al, 2021). 
Figure 6. The Term Funding Facility provided a large amount of low-cost funding for banks

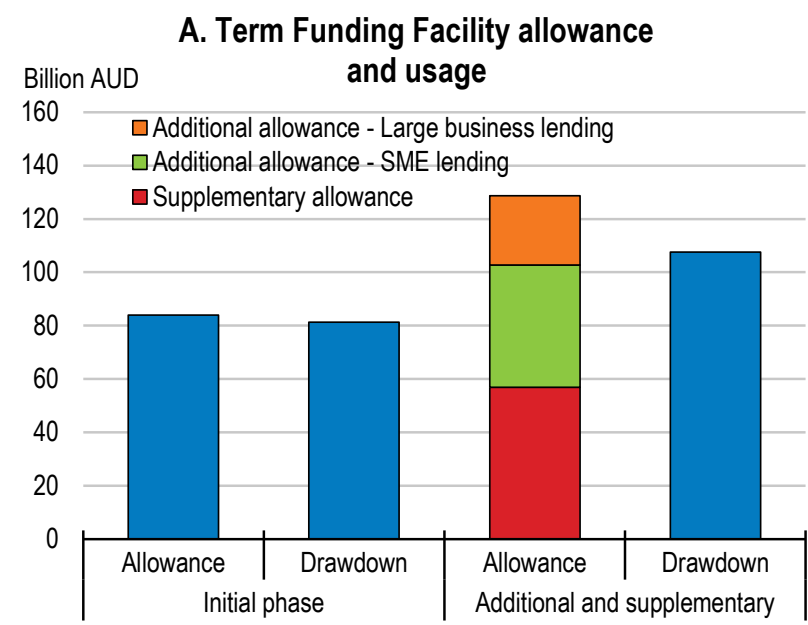

\section{B. Indicators of major banks' funding costs}
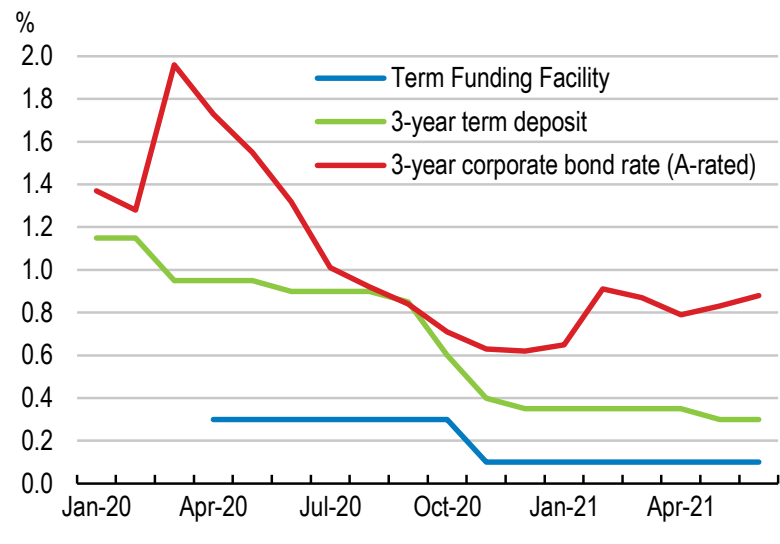

Note: Data in Panel $A$ are at 30 June 2021. The additional allowance for SME lending was equivalent to five times additional SME lending while the allowance for large business lending matched additional lending. Panel B shows yields on 3-year non-financial corporate bonds rated $A$ by S\&P; the four-largest banks are rated $A$ -

Source: RBA.

StatLink त्ञाज https://stat.link/fy2m0v

Two further measures provided far-reaching liquidity support for households: loan deferrals and early access to superannuation savings. The loan deferrals recognised the damaging spillovers if widespread defaults due to COVID-related measures led to foreclosures and firesales. At the peak, in May 2020, loan deferrals represented $11 \%$ of outstanding housing loans and $18 \%$ of SME loans. With debt-servicing accounting for $15 \%$ of household incomes before the pandemic, this relief provided a large buffer. Loan relief was especially useful for firms: prior to the pandemic around half only had enough cash for one month's worth of expenses (RBA, 2020a). The deferrals unwound as the economy bounced back (Figure 7, Panel A). In late 2020 and early 2021, banks reduced their provisions in anticipation of lower-than-expected losses (Figure 7, Panel B). The Australian Banking Association signalled that banks will work with borrowers who cannot return to full repayments to restructure loans, accommodate partial payments or assist them through financial hardship processes. Following the re-imposition of COVID-19 restrictions in July 2021, the sector again offered loan deferrals for affected customers and APRA has again offered regulatory relief. 
Figure 7. Most deferrals from the initial phase unwound at an orderly pace

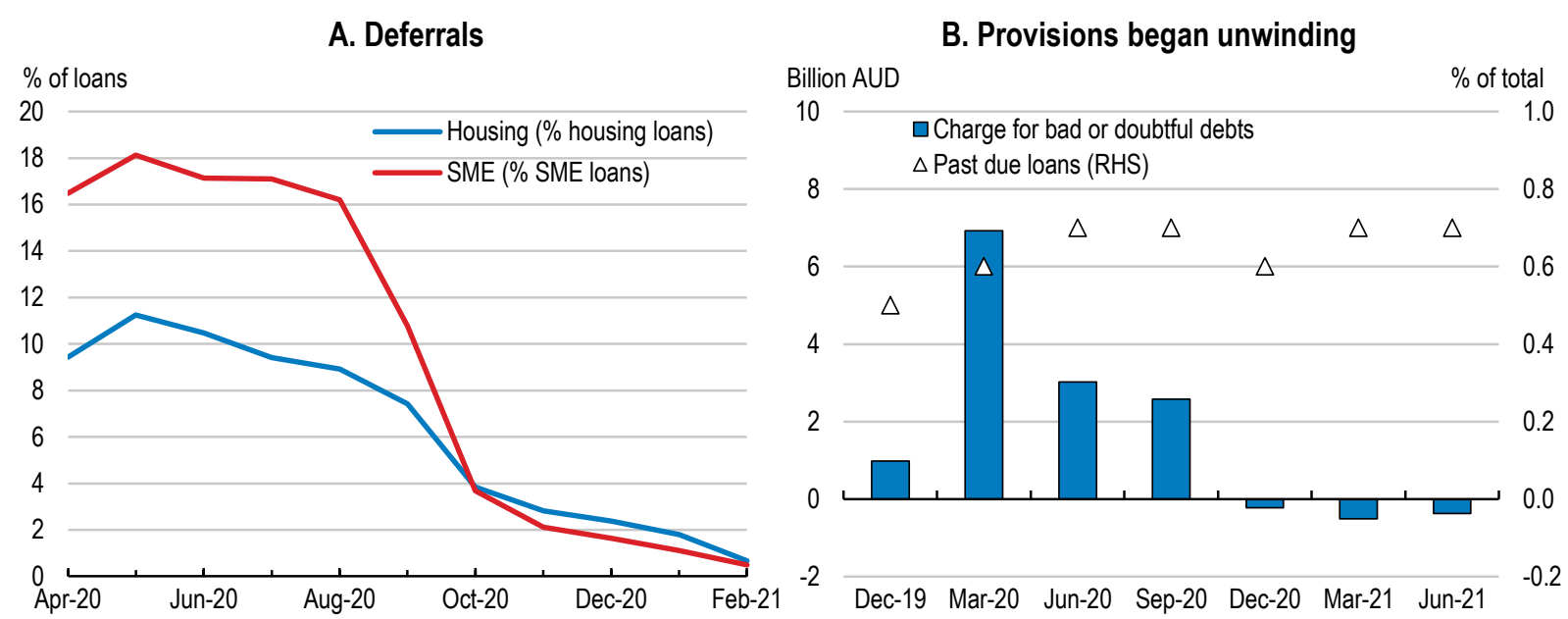

Note: In Panel A data prior to June are from the largest 20 authorised deposit-taking institutions by loan size. Data from June to September do not include foreign branches. Data from October from all authorised deposit-taking institutions with over AUD20 million of loans subject to repayment deferral excluding foreign branches. Past due items are items that are 90 days or more in arrears but are not classified as impaired assets.

Source: APRA.

StatLink त्ञाज https://stat.link/yfzb30

In March 2020 the government announced that affected individuals could supplement their income by withdrawing up to AUD20 000 (EUR12 000) (in two phases) from their superannuation savings if they were financially affected by the pandemic. Between April and January AUD36.4 billion was paid to over 3 million individuals, equivalent to $3.5 \%$ of household gross disposable income in that period. This represented $2 \%$ of total funds under management at end 2019 but over $5 \%$ for a large number of funds (RBA, 2021). During the first two weeks alone, AUD6 billion was withdrawn, which put pressure on funds but was handled smoothly overall (APRA, 2020b). There are also concerns that many individuals did not sufficiently evaluate their decision: in one survey around half of applicants underestimated or did not estimate the impact on retirement savings (Bateman et al, 2020). This was despite the availability of online tools such as the Super Withdrawal Estimator on the ASIC Moneysmart website. Although this was a source of liquidity during exceptional circumstances, further withdrawals should continue to be limited to cases of severe hardship as recommended by the OECD and International Organisation of Pension Supervisors.

\section{Flattening the insolvencies curve}

Notwithstanding the strength of the recovery up to mid-2021, insolvencies are expected to rise. Whether they rise beyond pre-pandemic levels remains highly uncertain. During 2020 there were over 6000 fewer corporate and business-related personal insolvencies than "usual" thanks to temporary changes to insolvency laws and measures that boosted liquidity and maintained capital market functioning (Table 3; Figure 8). By contrast, the observed decline in revenues implies that the number of business insolvencies in the first half of 2020 would have been almost 1.3 times what was observed (RBA, 2020a). Many viable businesses and individuals were successfully prevented from being forced into insolvency, reducing the financial, economic and social costs of the crisis. Nevertheless, some businesses will need to close while others pivot to adjust to a post-COVID economy. Even if a wave of insolvencies is avoided, a return to more normal levels of insolvencies is almost inevitable. OECD research shows that efficient insolvency regimes facilitate exit of unviable firms or restructuring of viable firms facing temporary distress at an earlier stage, raising productivity (Andrews et al., 2017). Higher recovery rates should improve access to finance. 
Figure 8. There have been far fewer business insolvencies than usual
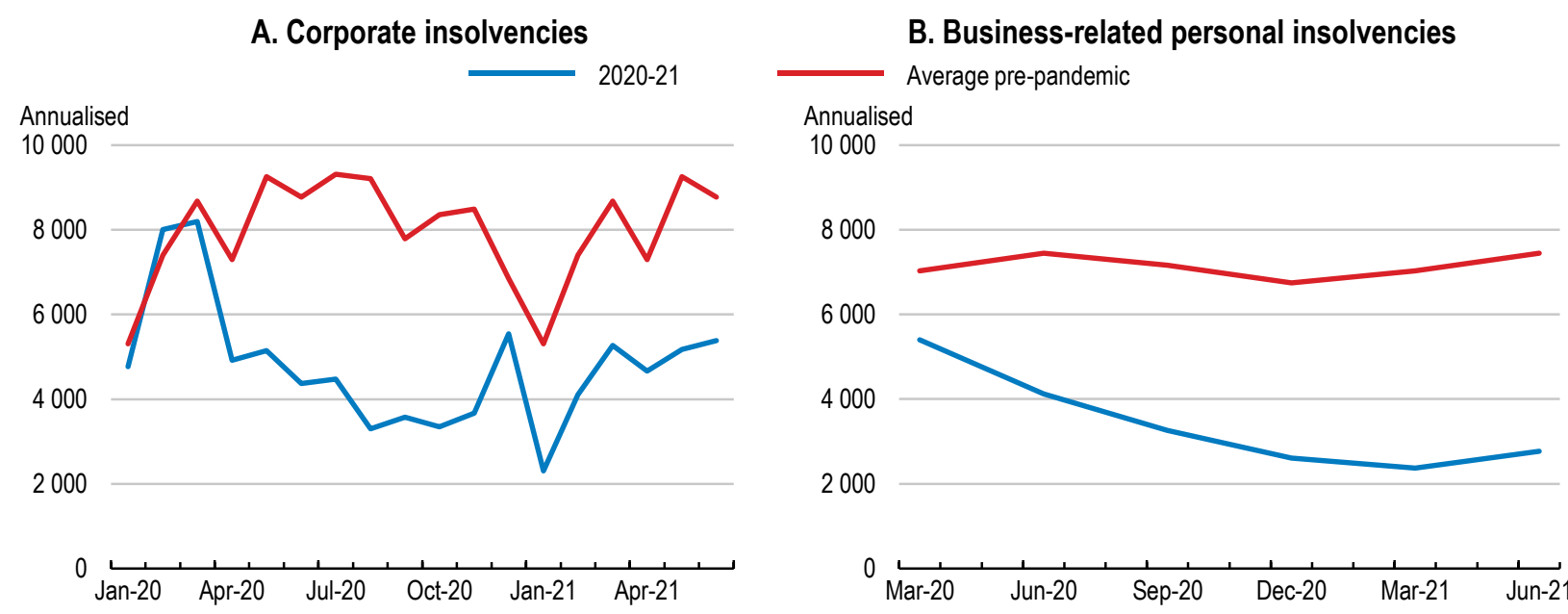

Note: The pre-pandemic average is that for each respective month during 2017-19. Data in Panel A are for the first instance of an insolvency appointment to a company.

Source: AFSA; ASIC.

StatLink त्ता

Recognising that small businesses have been most affected by the pandemic and comprise most insolvencies, the government has created a special restructuring process and simplified liquidation process for incorporated SMEs (Box 2). The reform addresses the disproportionate cost faced by SMEs under the previous one-size-fits-all approach and brings Australia more in line with other countries (Figure 9). Because the owner retains control, the process encourages earlier action, which should preserve economic value and reduce the number of firms being liquidated (OECD, 2020b). It should also reduce personal insolvencies associated with business owners using personal assets as collateral or personal guarantees. Simplified liquidation will facilitate higher recovery rates. The changes also allow more processes to be performed digitally and to hold meetings virtually. With three-quarters of firms entering administration in 2018-19 having liabilities below the AUD1 million (EUR620 000) threshold for this regime, the reform could reduce liquidations considerably (Australian Government, 2020). The reforms should increase access to finance if recovery rates improve as hoped.

\section{Box 2. Overview of changes to Australia's insolvency laws}

At the beginning of the pandemic, temporary changes to corporate and personal insolvency laws raised various thresholds to prevent otherwise viable firms being forced into insolvency and individuals being forced into bankruptcy due to circumstances beyond their control (Table 3). These expired on 31 December 2020 and were immediately followed by permanent changes to make the regime more debtor-friendly and simplify the insolvency process. The minimum amount of debt that can trigger personal bankruptcy was raised to AUD10 000 (from AUD5 000; EUR6 200 from EUR3 100). As part of the 2021 Budget, the Government announced an increase in the equivalent minimum threshold for a company from AUD2 000 to AUD4 000. Eligible incorporated small businesses (with less than AUD1 million in liabilities) now have access to two new processes:

- A formal debt restructuring process with a debtor-in-possession model. A "small business restructuring practitioner" will support the development of a restructuring plan, certify it and manage disbursements.

- A simplified liquidation pathway with reduced investigative and reporting requirements for liquidators. This aims to reduce liquidation costs, preserving more of the company's value. 
These changes enhance the prevention and streamlining toolkit thereby rationalising the insolvency framework, which was previously more restrictive than most OECD countries (Figure).

To increase the supply of practitioners the government is waiving registration fees for registered liquidators for around two years, adjusting some registration requirements for insolvency practitioners, and creating a separate sub-classification of practitioner which can only perform small business restructuring.

\section{Figure 9. Australia's insolvency laws have become more friendly to entrepreneurship}

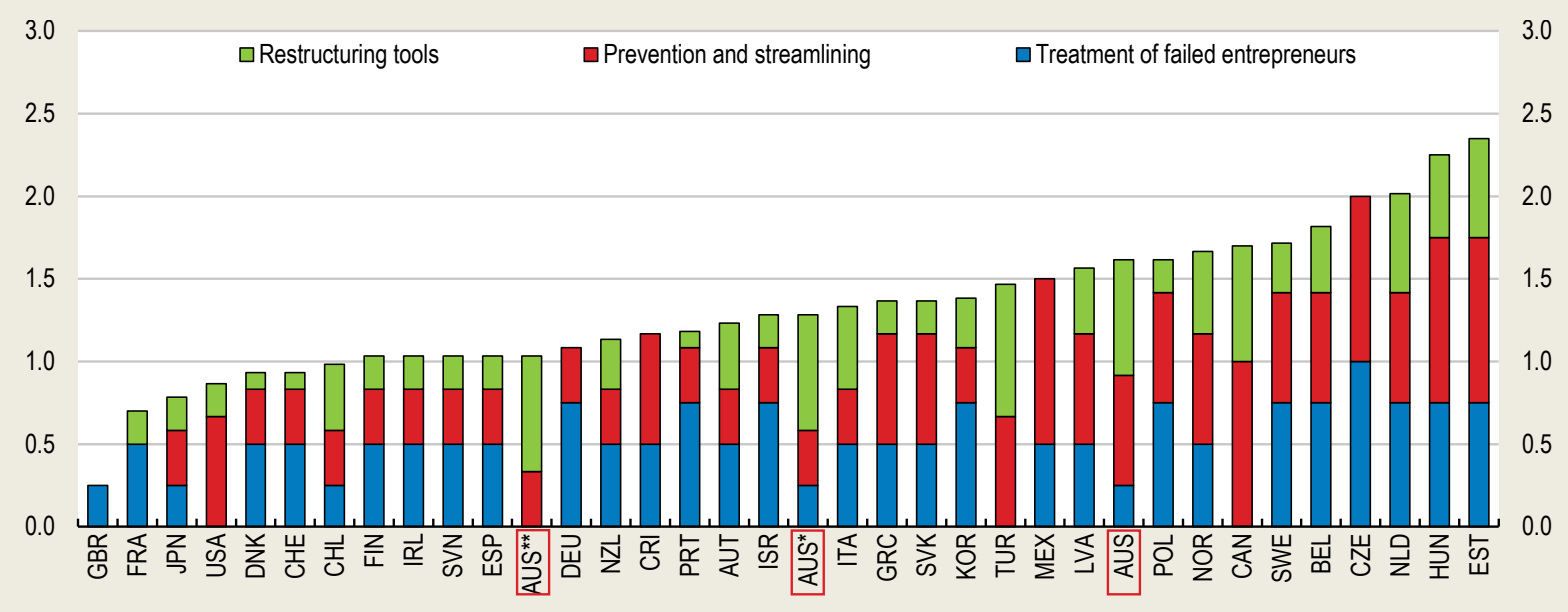

Note: A lower value indicates a regime that is less punishing for entrepreneurs, has more measures for prevention and with fewer barriers to restructuring. Data are for 2016 unless otherwise indicated. A number of countries introduced reforms during the crisis. AUS* denotes Australia's score at the beginning of 2021. AUS ${ }^{* *}$ allows for proposed changes to personal bankruptcy laws.

Source: OECD

StatLink त्ञाज़ https://stat.link/a6bcl3

The government is also clarifying the treatment of trusts with corporate trustees under Australia's insolvency law and consulting on further reforms, including:

- Reducing the default period of personal bankruptcy from three years to one year, along with some other time periods. It would be accompanied by extended income contribution obligations for discharged bankrupts.

- Ways of increasing the uptake of debt agreements and personal insolvency agreements, which are alternatives to personal bankruptcy.

Schemes of arrangement (a procedure allowing a company to reconstruct its capital, assets or liabilities with the requisite approval of affected parties) processes to better support businesses, including by introducing a moratorium on creditor enforcement while schemes are being negotiated

Source: Australian Government (2020), "Insolvency reforms to support small business", Factsheet

The government can enhance the effectiveness of the new processes in several ways. First, it should closely monitor the number of registered practitioners; the number of registered liquidators (most of the insolvency practitioners) declined steadily during the 2000s to around 650 currently. The reforms would likely increase demand for these services. The government should react quickly if insolvencies rise sharply and bottlenecks emerge (Box 2). Second, it should address problems with the Personal Property Securities Register (a register of secured interests in personal property offered as collateral) raised by the small business ombudsman and earlier reviews to ensure certainty over security interests, discussed further below (ASBFEO, 2021; PMC, 2020; Whittaker, 2015). Third, pre-emptive action should be encouraged by promoting existing services for businesses and individuals such as early warning tools, the National Debt 
Hotline and free financial counselling services. The pre-existing shortfall in financial counsellors should also be addressed (Sylvan, 2019). While the economy is still recovering from the pandemic, vouchers for a "business viability review" - suggested by the small business ombudsman - could be offered to particularly hard-hit SMEs. Before doing so, it should be ensured that there is adequate availability of suitable professionals to undertake them based on coverage and expected take-up.

There is scope to further align the insolvency regime with efficient regimes in other countries, particularly by lowering barriers to restructuring. Allowing management to retain control of the company during restructuring could better align private incentives of managers with those of owners so that initiation of solvency is not delayed. The "debtor-in-possession" model in the new small business debt restructuring process is a positive development in this regard. However, Australia and Israel are the only OECD countries where management loses control during restructuring (Adalet McGowan and Andrews, 2018). Many other OECD countries also allow creditors to initiate restructuring, whereas only secured creditors can in Australia. In early 2021, the government consulted publicly on possible changes to the personal insolvency regime, including to allow discharge after one year rather than three. The possibility of a "fresh start" for honest entrepreneurs could foster productivity growth by increasing firm entry, allowing failed entrepreneurs to implement lessons from their previous business and attracting better quality entrepreneurs (Adalet McGowan and Andrews, 2018). The unusual cause of the recent recession may justify trialling the regime to limit the scarring effects of the pandemic.

\section{Maintaining financial stability}

The strong recovery in 2020 reduced risks to financial stability compared to expectations in the early stages of the pandemic. Bank profitability declined sharply in the first half of 2020 with the overall return on equity falling by around 4 percentage points (RBA, 2021). But in the second half of the year, around half of the fall was unwound. While banks have benefited from lower funding costs including via the Term Funding Facility, net interest margins of the major banks have come under some pressure from higher liquid asset holdings and lower returns on bank assets, including due to strong competition in the home loan market. As mentioned above, measures taken by regulators had buttressed bank capital ratios going into the crisis. During 2020, regulators ensured that banks accumulated capital by reducing dividend payments. This was also achieved through dividend reinvestment plans and (in one case) by raising equity. The ratio of capital to assets across all banks was around the OECD median in 2020, up from one of the lowest five years earlier (Figure 10, Panel A). This reflects the abovementioned efforts to strengthen bank balance sheets after the 2014 Financial System Inquiry. Liquidity ratios rose during 2020 as a result of the Term Funding Facility, strong deposit growth and lower demand for credit (RBA, 2021). Although non-performing loans have ticked up, they are relatively low (Figure 10, Panel B) due to the pandemic policy measures that supported borrowers' liquidity and lowered insolvencies and macroprudential interventions prior to the crisis that improved lending standards. 
Figure 10. Banks are well capitalised and asset quality has only deteriorated modestly

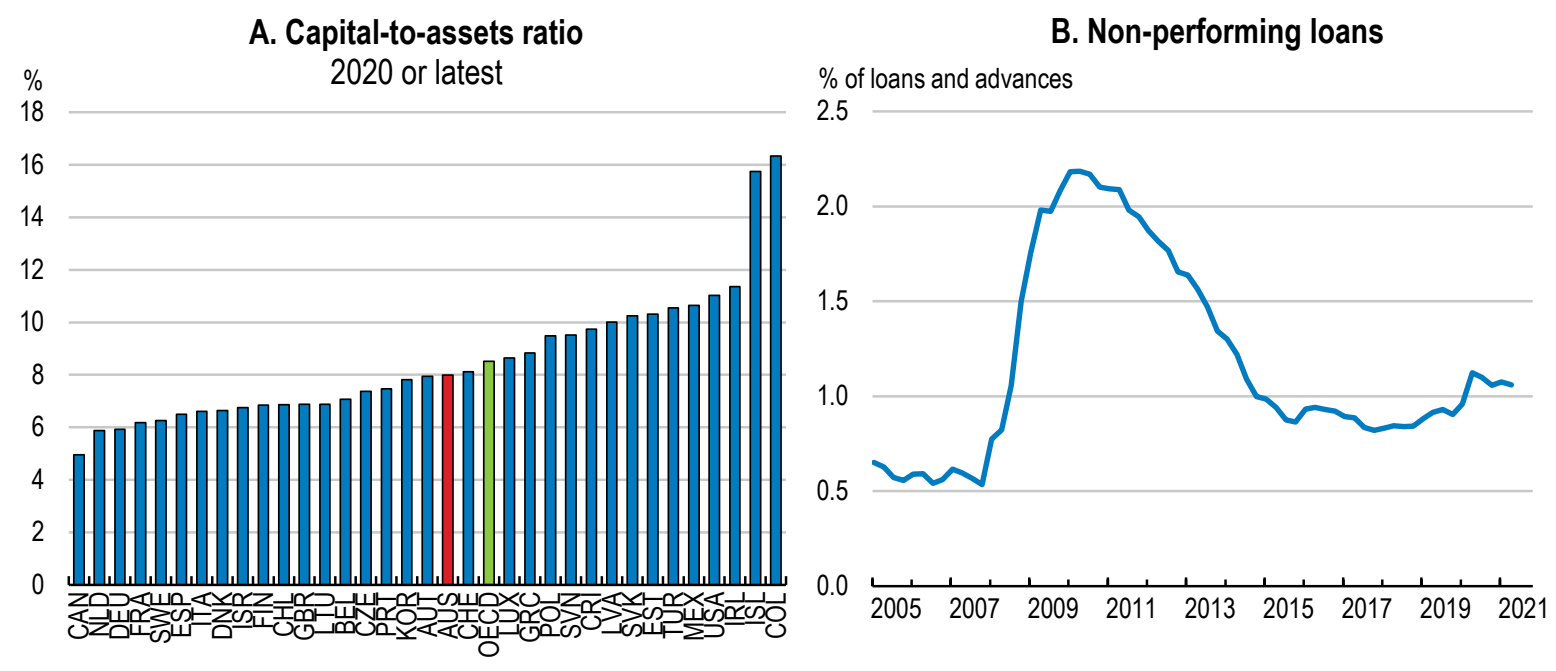

Note: In Panel B there is a break in June 2019 due to changes in data collection. Loans affected by the COVID-19 loan repayment holidays from March 2020 to 2021 were permitted to be classified as performing.

Source: APRA; IMF, Financial Soundness Indicators database.

StatLink :

As highlighted by past Economic Surveys of Australia, banks' high exposures to real estate together with high level of household indebtedness are a potential economic and financial stability risk (OECD, 2018a, 2017a). Real estate exposures are the highest in the OECD (Figure 11, Panel A). Household debt ratios measured by the ratio of debt to income or to GDP - are amongst the highest (Figure 11, Panel B). Declining interest rates have reduced the household sector's debt-servicing burden, although it is still comparatively high (Figure 11, Panel C). This debt is mirrored by high holdings of housing assets, both as owner-occupiers and investors, with total real estate assets equivalent to $59 \%$ of household assets on average in 2018 (Wilkins, 2020). (Superannuation assets account for around one-fifth of assets but are generally not accessible before age 65.) Rising house prices are now reducing the leverage of existing borrowers but raising borrowing requirements for new ones (Figure 11, Panel D). Around half of all mortgages had accumulated prepayment buffers equivalent to at least three months of repayments in early 2021 , but around $40 \%$ had one month or less, with relatively riskier loans accounting for $10 \%$ of total mortgages (RBA, 2021). Notwithstanding the deterioration in the economic outlook in recent months, risks are somewhat moderated by the reduction in negative equity and the improvement in lending standards in recent years. New lending with high loan-to-valuation ratios has been concentrated in owner-occupier debt, which is considered less risky than investor debt. 
Figure 11. Household debt and bank exposures to real estate are high
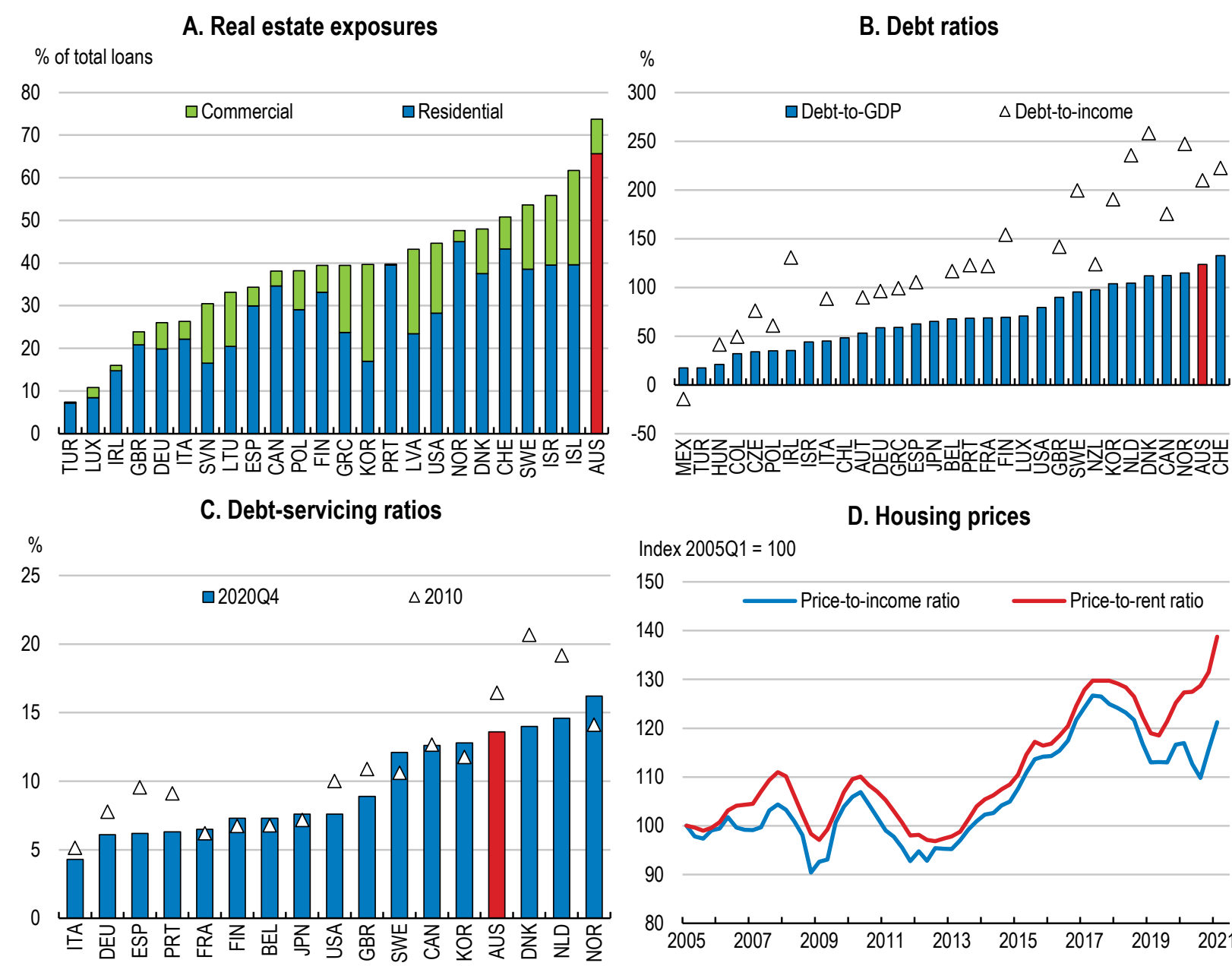

\section{Housing prices}

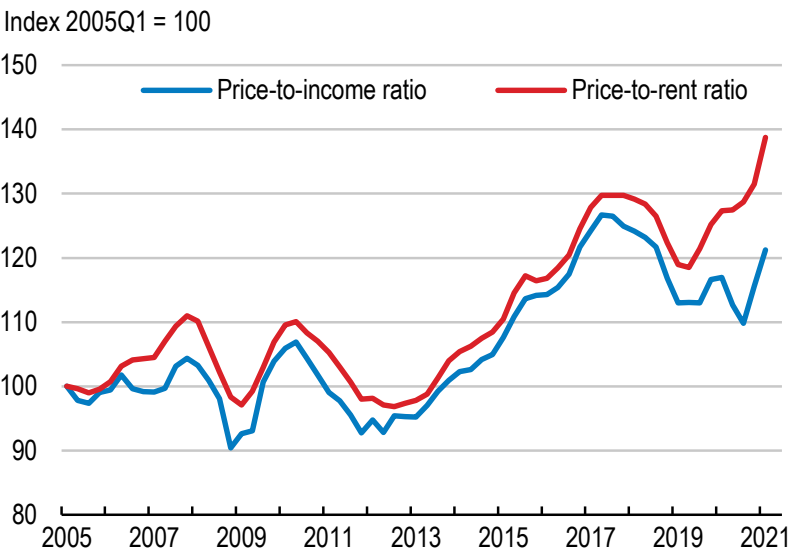

Note: Data in Panel A and B are for 2020 or latest available. In Panel B the debt-to-GDP ratio refers to loans, debt securities, currencies and deposits; the debt-to-net-disposable-income ratio is from the national accounts, which is slightly broader.

Source: BIS; IMF, Financial Soundness Indicators database; OECD, National Accounts database; OECD, Housing Prices database.

StatLink त्राज़ https://stat.link/eyzg0m

Commercial property appears to be a greater source of near-term risk. The pandemic accelerated the structural change in retail shopping, while changed working habits have reduced demand for office space. In both sectors vacancy rates have risen. In some cities office vacancies reached two-decade highs at end 2020 (RBA, 2021). Exposures amounted to $8 \%$ of banks' loans in 2020 , compared to around $10 \%$ in OECD countries with available data. But at some banks exposures amount to $16 \%$ of total assets (RBA, 2021). Additional exposures arise due to businesses using their commercial property as security. Non-bank lenders are also exposed to the sector. Valuations of commercial property are only required annually (unless markets move significantly) and were suspended during 2020.

In its April 2021 review, the RBA considered near-term financial stability risks to be manageable (RBA, 2021). Bank stress tests in 2020 concluded that the system could weather a $15 \%$ fall in GDP, accompanied by a $13 \%$ unemployment rate, $30 \%$ fall in housing prices and $40 \%$ fall in commercial property prices (APRA, 2020a). The industry-wide capital ratio would fall by 5 percentage points and remain above the minimum capital ratio. While the stress test concluded the sector would be able to lend and support the economic recovery, in practice it would be weakened and may be unwilling to lend without policy support. The entity- 
level stress test results were not released. In most OECD countries individual results are published, at least some of the time (OECD, 2020c). In a crisis this can be useful to address concerns that institutions may have adverse private information, if credible and complemented by measures such as remedial actions for poorly performing institutions and well-funded backstops to mitigate risks of destabilisation (Baudino et al., 2018). APRA should continue to monitor risks closely and ensure that banks are appropriately recognising risks on their loan books, particularly with commercial property. Supervisors should also ensure that they have sufficient data to understand the risks and interlinkages between banks and non-banks, which is a greater risk in commercial property.

Housing debt will remain a source of medium-term vulnerability for Australian banks and households. Low wage growth means that some highly indebted households will take longer to accumulate buffers than in the past, and therefore be exposed to adverse income shocks for longer. High nominal debts can also weigh on household consumption (Price et al., 2019; Mian et al., 2015). Lower interest rates reduce debtservicing burdens for existing borrowers but also increase borrowing capacity. Lenders must apply a $2.5 \%$ minimum interest rate buffer when assessing loans. Nevertheless, there are risks of financial stress if interest rates were to rise faster than expected. A prolonged period of low interest rates would put further pressure on banks' net interest margins and incentivise faster credit extension or increased risk taking. In some other OECD countries where rates have been low for longer, such as Switzerland and Canada, housing prices and housing debt have risen notably. If credit growth accelerates and there are other signs of building risks, such as deteriorating lending standards, policymakers should implement targeted macroprudential measures to dampen the build-up of medium-term risks. The authorities successfully used various tools during 2014-18 to reduce risks associated with rising debt (Table 4).

The supervisor should continue to develop its toolkit of macroprudential interventions tailored to address emerging risks. Unlike in most OECD countries, Australia does not have a regulatory maximum loan-tovalue ratio (Figure 12, Panel A). OECD research has found that limits on loan-to-value ratios can reduce the risk of crisis but may weigh on the recovery (OECD, 2021a). In Finland, a 2019 working group on limiting household indebtedness recommended that the maximum loan-to value ratio be combined with a debt-to-income ratio of 4.5 times that could be exceeded in $15 \%$ of loans (FIN-FSA, 2020). Other effective macroprudential options to consider include higher capital requirements, through sectoral counter-cyclical capital buffers or higher risk weights on highly leveraged loans. Risk weights appear relatively low in Australia, although in practice the regulatory minimum capital ratio also affects settings (Figure 12, Panel B).

APRA is progressing its crisis resolution and recovery planning work after delays caused by the pandemic. In 2019, APRA increased total capital requirements to boost loss-absorbing capacity. APRA aims to release a new prudential standard for recovery and resolution planning for consultation by early 2022 , which will complete implementation of the reforms that started with the crisis-resolution legislation passed in 2018 and better prepare Australia in case of a severe downturn in the housing market. The 2018 OECD Economic Survey highlighted that a severe crisis could test the 2018 legislation as there are no explicit bail-in provisions on senior debt or deposits owned by financial institutions. The United States and European Union have such provisions. These provisions should be introduced to allow more flexible resolutions. 
Table 4. The authorities have used a range of policies to reduce financial stability risks

\begin{tabular}{|c|c|c|}
\hline Measure & Detail & Dates applying \\
\hline $\begin{array}{l}\text { Debt-to-income } \\
\text { ratios }\end{array}$ & $\begin{array}{l}\text { Bank boards were asked to restrict residential lending with debt-to-income ratios above } 6 \\
\text { but it is allowed. }\end{array}$ & April 2018 \\
\hline $\begin{array}{l}\text { Serviceability } \\
\text { standards }\end{array}$ & $2.5 \%$ interest rate buffer over current rate. & July 2019 \\
\hline \multicolumn{3}{|c|}{ Discontinued measures } \\
\hline $\begin{array}{l}\text { Investor lending } \\
\text { benchmark: }\end{array}$ & $10 \%$ of credit growth (more allowed but scrutinised) & $\begin{array}{l}\text { Announced December } \\
2014 \\
\text { Removed June 2018(a) }\end{array}$ \\
\hline $\begin{array}{l}\text { Interest-only loans } \\
\text { benchmark }\end{array}$ & $\begin{array}{l}30 \% \text { of new lending } \\
\text { Instruction of strict internal limits on interest-only loans with LTV }>80 \% \text { and scrutiny if } \\
\text { LTV }>90 \%\end{array}$ & $\begin{array}{l}\text { Announced March } 2017 \\
\text { Removed January } 2019 \text { (a) }\end{array}$ \\
\hline $\begin{array}{l}\text { Serviceability } \\
\text { standards }\end{array}$ & $2 \%$ interest rate buffer over current rate with minimum rate of $7 \%$. & $\begin{array}{l}\text { Announced December } \\
2014 \\
\text { Amended July } 2019 .\end{array}$ \\
\hline
\end{tabular}

(a) Investor lending and interest-only benchmarks were only removed where banks met the speed limit, provided assurances on lending practices and maintained serviceability standards.

Source: RBA (2018), "Assessing the Effects of Housing Lending Policy Measures" in Financial Stability Review, October 2020; C. Dobson (2020), "Assessing the effects of housing policy measures on new lending in Australia", BIS Papers, No. 119.

\section{Figure 12. Macroprudential policies could be tightened further}

\section{A. Borrower-targeted measures}

2019

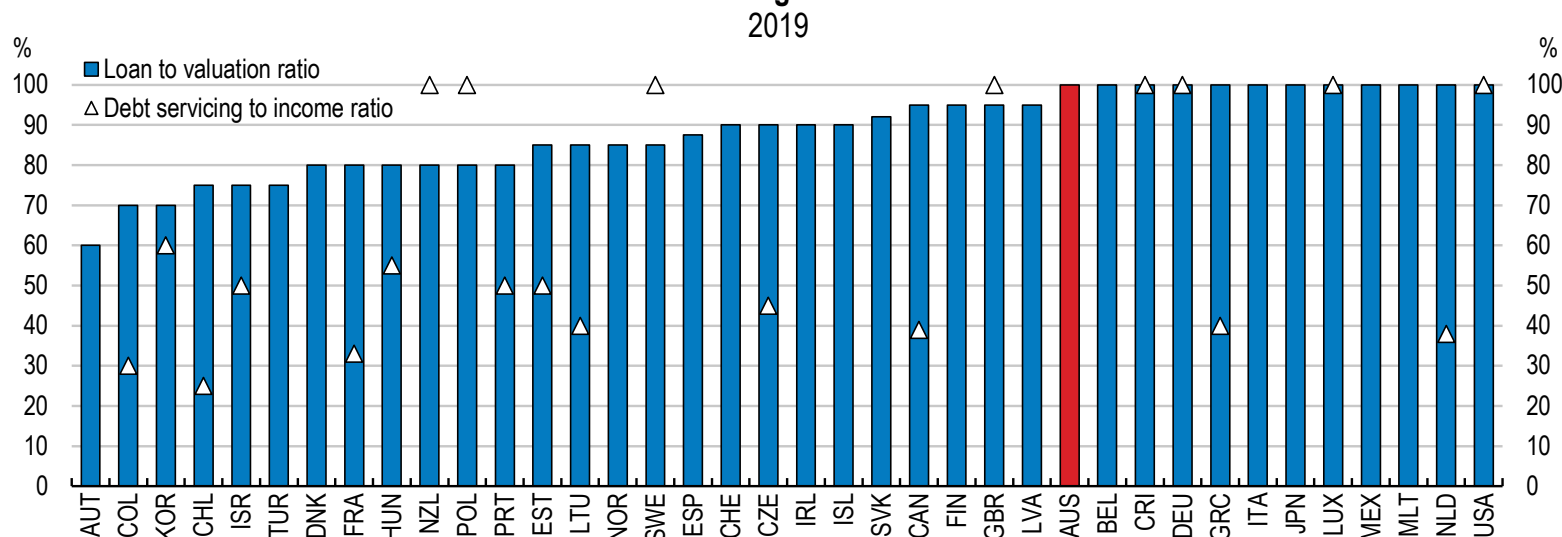

B. Lender-targeted measures

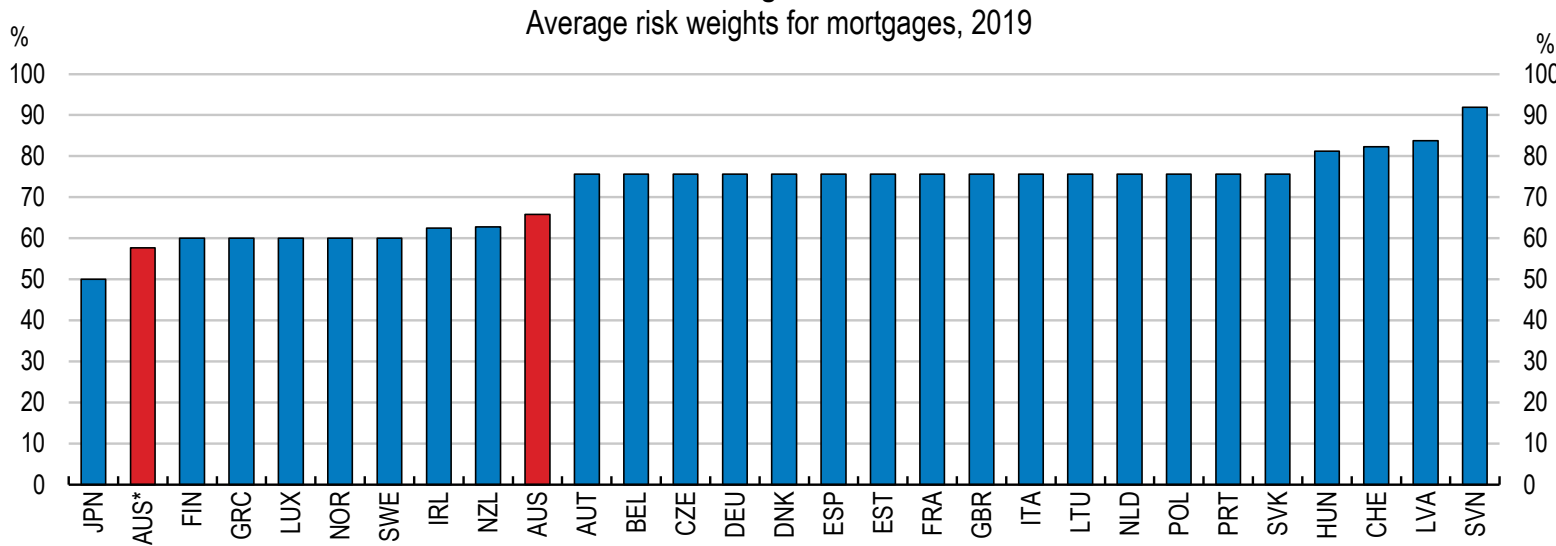

Note: In Panel A lower values denote more stringent measures. Australia and other countries with no maximum rate are shown at $100 \%$. In Panel B, higher values denote more stringent measures. Risk weights are the average for loan-to-value ratios of 50-130\%. The risk weights shown for Australia are for loans without lenders mortgage insurance. AUS* denotes the proposed average risk weight from 2023. Source: OECD (2021), Brick by Brick: Building Better Housing Policies; OECD. 
Tackling structural factors that might skew Australian household balance sheets towards residential property investment could reduce vulnerabilities and improve household wellbeing. For instance, the tax treatment of savings incentivises leveraged investments into assets that are expected to enjoy capital gains over time (Henry, 2009). While the capital gains tax discount is available on all investments, leveraging real estate is easier than other assets (RBA, 2015). Capital gains tax discounts for an individual's main residence are well in excess of inflation, at $50 \%$ for investments held for over a year and $100 \%$ for owneroccupied housing. In addition, expenses associated with earning investment income, including interest payments, can be deducted from personal income ("negative gearing"). Because households can deduct expenses from income but can choose when to realise the capital gain - such as when they face a lower marginal income tax rate - the discount also facilitates tax planning and breaches principles of tax neutrality.

One reform would be to replace the capital gains discount with cost-base indexation. In the first four years, this could add AUD4.1 billion dollars to government revenue $(0.6 \%$ of $2018-19$ general government revenue) (PBO, 2019). Some studies have suggested reducing the discount but keeping it at a fixed rate (Henry, 2009, Daley and Wood, 2016). Reducing the discount would also lessen inequality given that wealthier households tend to hold a greater share of their wealth in second properties and may better take advantage of tax planning opportunities. As Australia does not have an inheritance tax, exemptions for inherited properties should also be reconsidered. Consideration could be given to ring-fencing the income base against which investment-related expenses can be deducted (Daley and Wood, 2016; Henry, 2009). Such a change should be carefully designed to avoid dislocating the property market and follow more fundamental reforms tackling supply-side drivers of high prices. These include reforming land zoning and planning approvals to allow more high-density development. This would both improve housing affordability over the medium term and slow the pace of mortgage growth (OECD, 2021a).

\section{Channelling finance to viable and productive firms}

The financial sector will play a key role in determining the strength of the economic recovery by supporting the emergence and growth of productive firms. This is particularly important after the decade of weak investment and low productivity growth in Australia preceding the pandemic. Tackling financial frictions can improve the supply of finance to productive firms when uncertainty fades. These frictions are typically high for innovative high-growth firms that drive job creation and productivity growth (Calvino et al., 2016; Criscuolo et al., 2014). Screening and monitoring costs arising from information asymmetries impede finance for firms that lack history or collateral, as is the case for young firms and intangible investment such as research and development and innovation (Demmou et al., 2019; Heil, 2017; Andrews and Criscuolo, 2013; Hall and Lerner, 2010). A well-developed financial system will meet the needs of firms at different stages of growth. In addition, adjusting to the post-pandemic economy, including the acceleration of the digital transformation, will require a reallocation of resources across the economy and firms. The financial system can facilitate this.

Access to external finance has not been considered to be a general problem for Australian firms because they do not need additional funds, can use internal finance, or are able to access it (PC, 2018; Connolly and Jackman, 2017). Nonetheless, there are longstanding concerns about financing constraints for small and young businesses that remain important in the economic recovery (Kent, 2021; Connolly and Bank, 2018). Survey data from 2018-19 show that financial constraints affect smaller and innovative firms more (Figure 13). More recent data show that large differences in rejection rates by firm size persist (Figure 14, Panel A). More firms seek debt rather than equity finance, particularly from banks. For those that sought finance, difficulties were higher for equity finance but have increased over the decade after the global financial crisis for both types (Figure 14, Panel B). Since these surveys do not capture firms that were not created due to a lack of finance or were dissuaded from seeking finance, they may underestimate the size of the barrier. Firm-level analysis suggests these barriers are more binding for small and young firms: their investment is more sensitive to leverage and liquidity compared to large firms, which weighs on investment as they are less likely to have internal financing (IMF, 2020b). 


\section{4 | ECO/WKP(2021)51}

Figure 13. Access to finance is a barrier for innovative firms and innovation

Percentage of firms reporting constraint

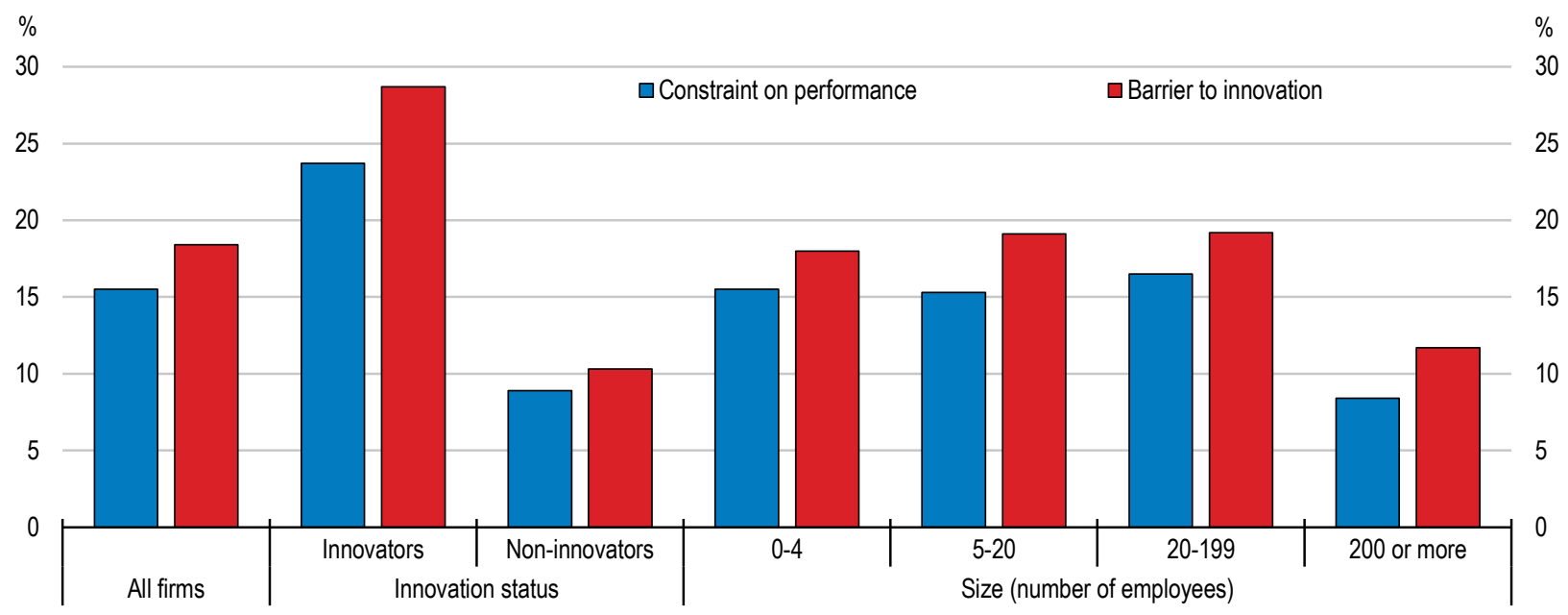

Note: Firms were allowed to provide multiple responses. Data are for 2018-19.

Source: ABS

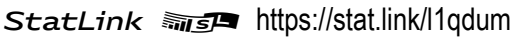

Figure 14. Obtaining finance has become more difficult

A. Outcome of seeking finance April 2021

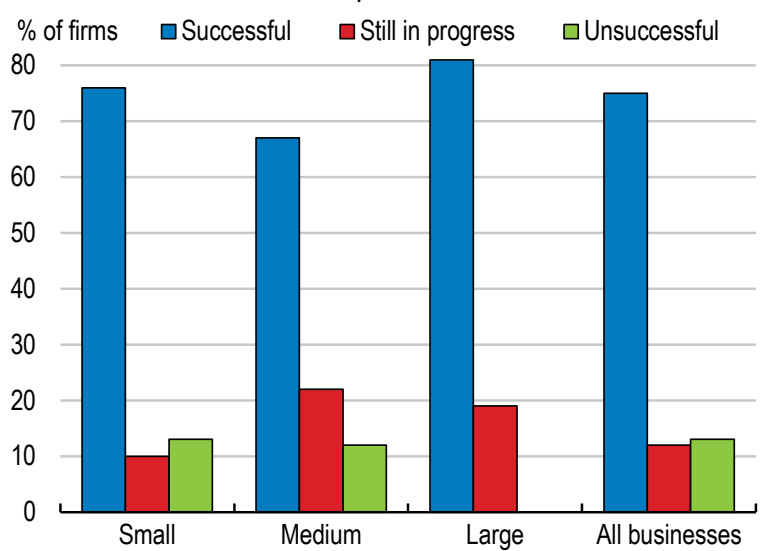

B. Sought finance but not obtained

Firms seeking each type of finance

$\%$ of firms

$60 \longrightarrow$ Debt Equity

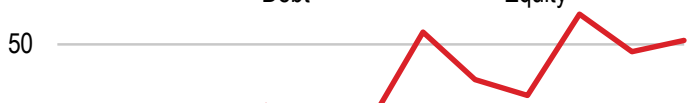

40

20

10

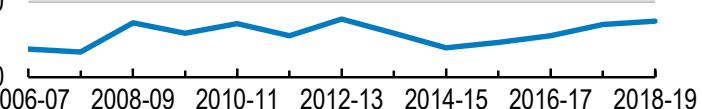

Note: In Panel B there is a break in 2009-10 when agriculture was included in the survey.

Source: ABS

StatLink त्ञाज https://stat.link/sfu3el 


\section{Improving access to credit}

Across countries banks are a key source of external finance for business as their informational advantages and ability to pool credit risks allow them to provide finance at a lower cost and without firms relinquishing any control. Empirical research suggests that the productivity benefits of financial deepening are realised via business lending, rather than household lending (Beck et al., 2012). However, bank lending has shifted towards households in Australia (Figure 15, Panel A). The IMF Financial Soundness Indicators show that the share of bank lending to the household (and not-for-profit) sector exceeds that in other OECD countries, for which the median is around $36 \%$. A range of factors have driven the demand and supply of lending in each sector. The role of policies is discussed further below.

Prior to the crisis, Australian entrepreneurs and start-ups reported difficulties accessing bank credit, as in many countries (Connolly and Bank, 2018). SME credit - an indicator of credit availability for young and innovative firms - amounted to $44 \%$ of business lending in 2019 compared to $47 \%$ in the average OECD country (Figure 15, Panel B). The gap for small firms (AUD1-AUD20 million in turnover) could be as high as AUD94 billion, or $10 \%$ of business credit outstanding (East and Partners, 2021). The equivalent gap for firms with AUD20-50 million in turnover is slightly larger. The cost of credit is also higher for SMEs, with the differential vis-à-vis large firms persistently elevated since the 2008-09 crisis and above the OECD median country (Figure 16). Furthermore, banks' preference for security, particularly real estate, constrains businesses without acceptable collateral. This is more likely to affect high-growth firms rich in intangible assets. RBA data show that $95 \%$ of all SME loans are secured, and half of all small business loans are secured by residential property. In the median OECD country for which data exist, around $60 \%$ of SMEs report being required to provide collateral on their latest bank loan (OECD, 2020d).

\section{Figure 15. Lending is highly skewed towards households}

\section{A. Credit by sector}

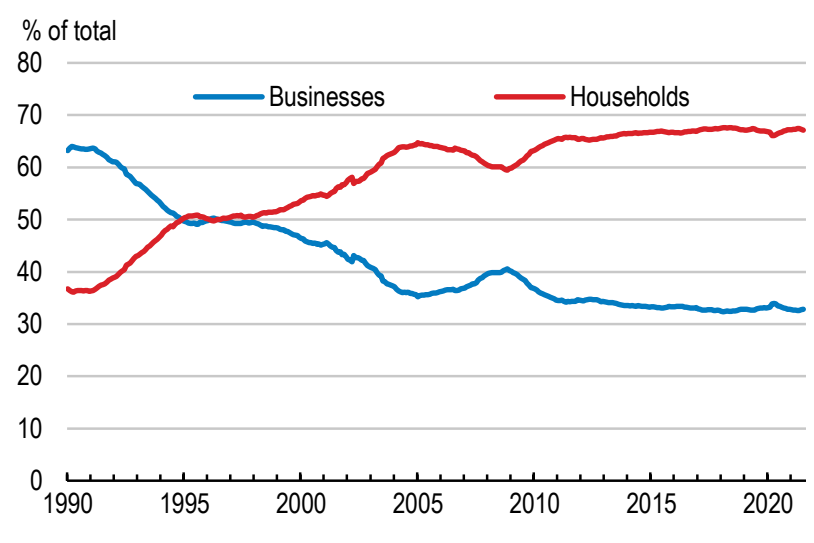

\section{B. SME lending} 2019

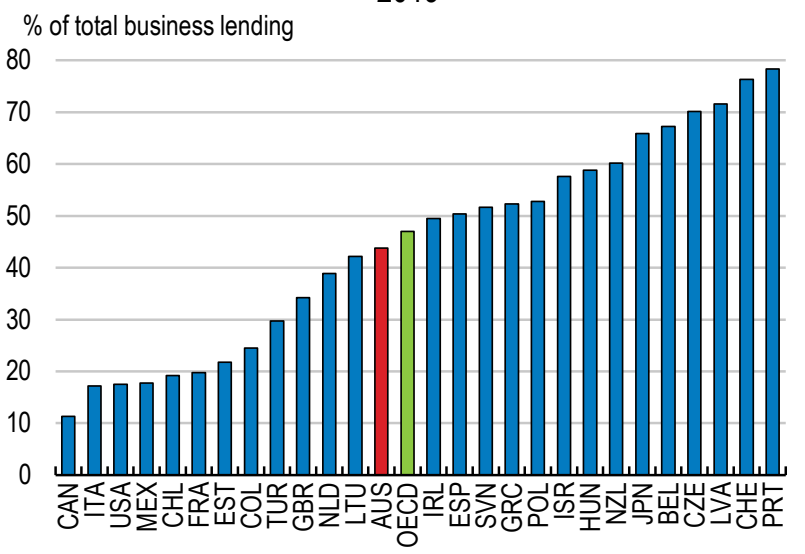

Note: In Panel A there are series breaks in July 2019.

Source: OECD, Financing SMEs and Entrepreneurs: An OECD Scoreboard database; RBA. 
Figure 16. The interest rate spread on SME loans is relatively wide

Interest rate spread between SME and large firm loans, 2019

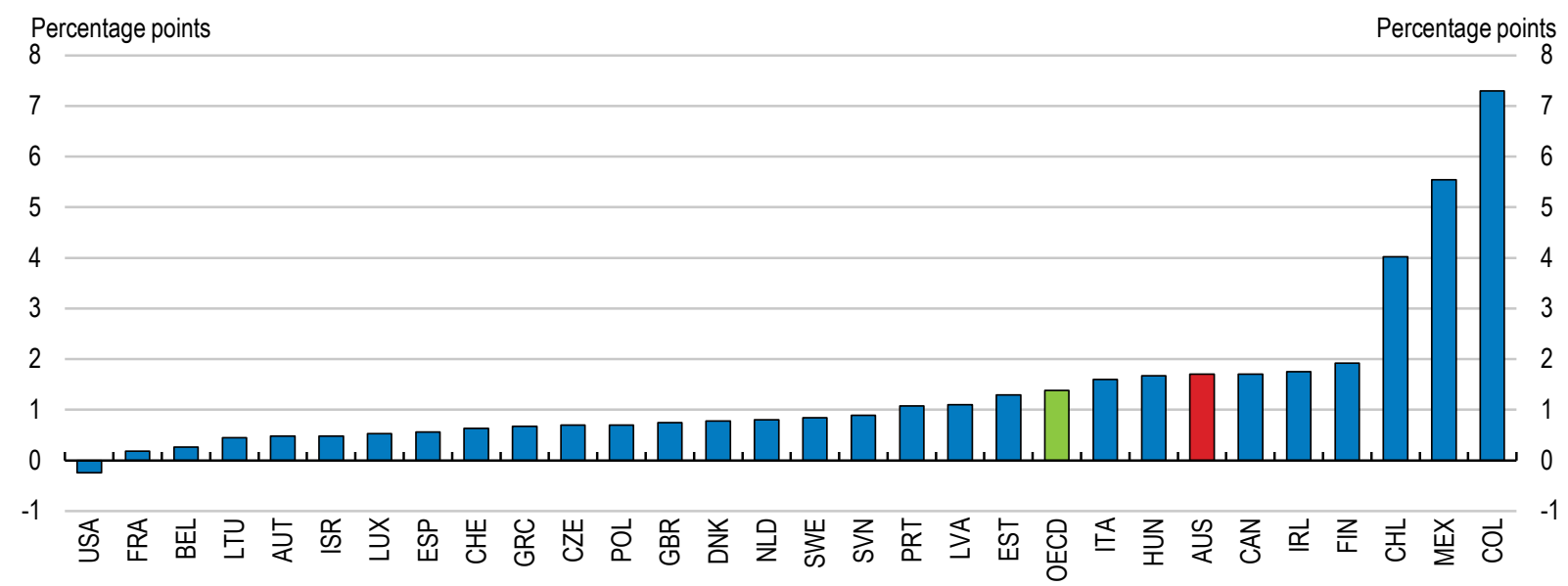

Source: OECD, Financing SMEs and Entrepreneurs: An OECD Scoreboard database.

StatLink त्गाड़ https://stat.link/u5nsw0

Policy and regulations affect the allocation of capital and can create stronger incentives for banks to extend mortgages than business loans. First, for all banks using the standardised risk weights for calculating regulatory capital, weights for housing lending are considerably lower than for small business lending unless the loan is secured by residential property (Table 5). Lending to smaller businesses is risker on average but the Australian risk weights are higher than in other countries (PC, 2018). From 2023 when revised prudential standards take effect, risk weights on unsecured SME loans will be aligned with Basel III which is also taking effect in 2023 and commercial property will be recognised as collateral (also consistent with Basel III; Table 5). Second, funding costs for mortgages are lowered by the ability to selfsecuritise residential mortgage-backed securities for use as collateral in repurchase agreements with the RBA, for example for the Term Funding Facility. In addition, mortgages are more profitable because screening and monitoring costs are lower and assessment is more formulaic compared to heterogeneous business loans (PC, 2018). Taken together these factors weigh on the supply of lending for firms.

Table 5. Risk weights are high for SME loans unless secured by residential property

\begin{tabular}{l|r|r|r}
\hline & \multicolumn{3}{|c}{ Standardised approach } \\
\hline & \multicolumn{1}{|c|}{ Current } & Basel III & Proposed \\
\hline Unsecured - retail & 100 & 75 & 75 \\
\hline Unsecured - corporate & 100 & 85 & 85 \\
\hline Secured by commercial property used by business & 100 & $70-110$ & $70-110$ \\
\hline Secured by residential property & $35-100$ & $20-70$ & $25-105$ \\
\hline Memo: owner-occupier mortgage & $35-100$ & $20-70$ & $20-85$ \\
\hline
\end{tabular}

Note: An SME is currently defined as having annual revenue of AUD50 million, or EUR50 million under Basel III and AUD75 million in the proposed revised standards. A retail SME loan will be up to AUD1.5 million. The risk weights for "Unsecured-corporate" reflect those for unrated corporate SME exposures. For loans secured by property the risk weight varies by loan-to-value ratio over the range shown.

Source: Productivity Commission (2018), Competition in the Australian Financial System, Productivity Commission Inquiry Report, No. 89; Bank for International Settlements; APRA (2020), Draft Prudential Standard APS 112: Capital Adequacy: Standardised Approach to Credit Risk. 
A lack of competitive pressures can restrict access to finance via cost, product availability and the terms on which finance is offered. The Productivity Commission found that large banks' market power results from (i) an established presence; (ii) regulatory arrangements; (iii) funding advantages and operational efficiency; (iv) horizontal and vertical integration; and (v) lack of switching by customers (PC, 2018). In the mortgage market, they have wielded sufficient power to pass on costs of new regulations (ACCC, 2018; PC, 2018). Consolidation may have benefitted competition through mergers between smaller players that allow them to better compete with larger banks (PC, 2018; Figure 17, Panel A). Nonetheless, the largest banks still account for $77 \%$ of all lending by authorised deposit-taking institutions, more than before the 2008-09 crisis (Figure 17, Panel B). Concentration is also high by international comparison (Figure 3). Measures of market structure suggest that business lending is somewhat more competitive (Figure 17, Panel C). However, this largely reflects foreign banks' lending to large businesses; over $80 \%$ of SME lending was with the major banks in 2017 (PC, 2018). Although it may be too small to affect these metrics, the 2019 entry of an SME-focussed bank should improve conditions in SME lending. Under the SME Recovery Loan Scheme, around $40 \%$ of lenders approved to participate to date are non-banks. There are signs the power differential between large and small banks narrowed over the past decade but it is still large (Figure 17, Panel D).

\section{Figure 17. The major banks have remained entrenched}

\section{A. Number of entities}

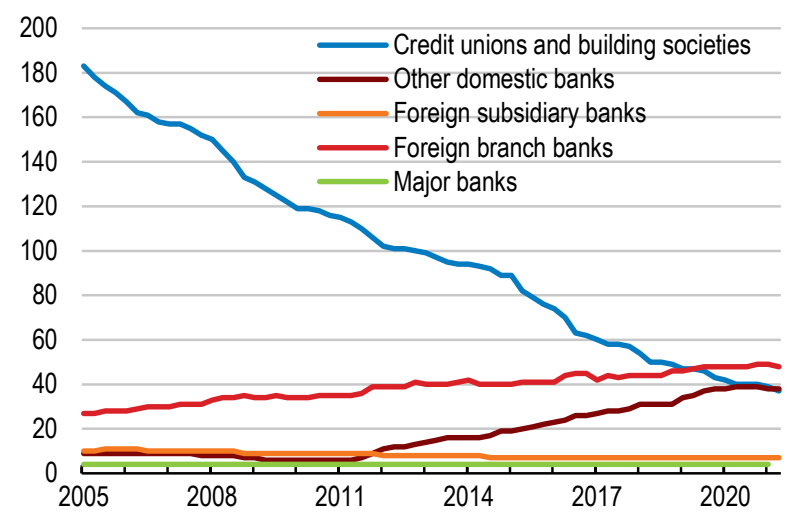

C. Herfindahl-Hirschman Index

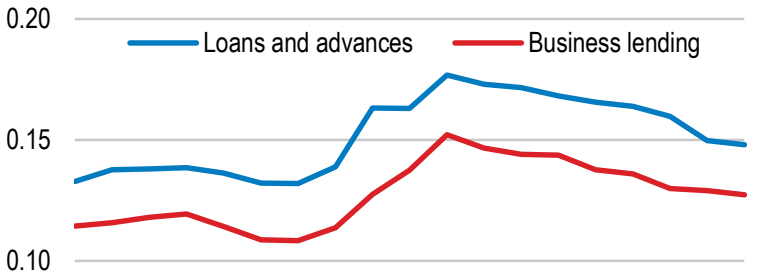

0.05

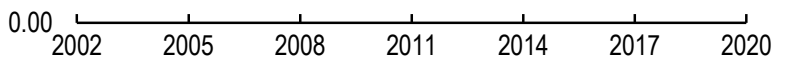

\section{B. Share of gross loans and advances}

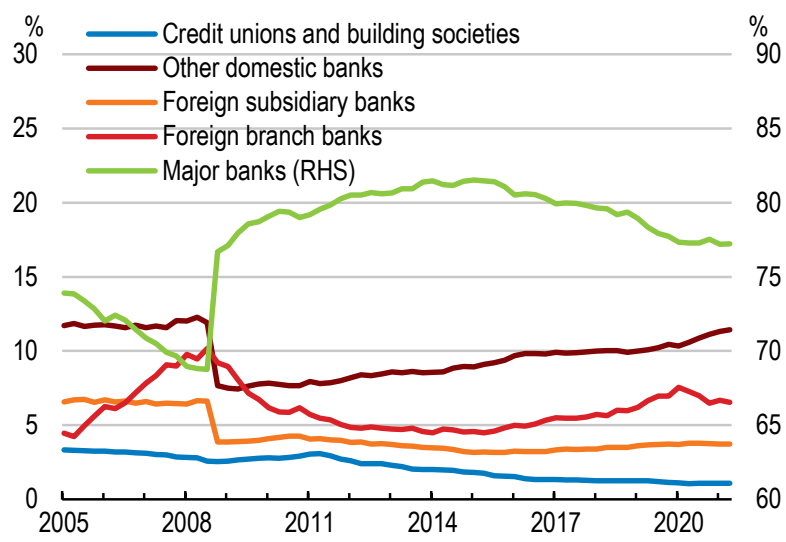

D. Lerner index for Australian banks
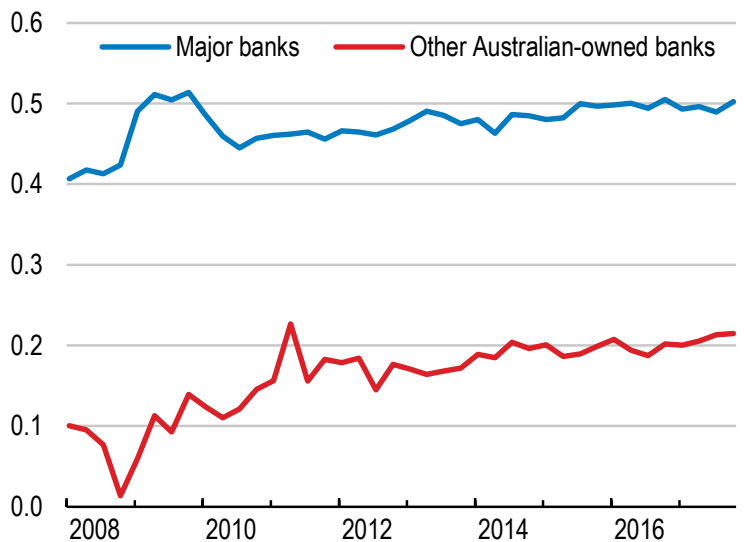

Note: In Panel $\mathrm{C}$ data are at December. The Herfindahl-Hirschman index measures concentration. A higher value indicates a more concentrated market. The Lerner index shows the extent to which interest rates exceed marginal cost. A higher value indicates more market power.

Source: APRA; Productivity Commission (2018), Competition in the Australian Financial System, Productivity Commission Inquiry Report, No. 89; OECD calculations. 
This policy landscape and competition dynamics are potential explanations for the wider credit spreads and tougher financing terms facing smaller businesses described above, with the pandemic worsening conditions during 2020. However, monitoring developments and disentangling supply- and demand-side factors to understand the financing gap is challenging given available data. The main publicly available data sources are: (i) the statistics office's annual Business Characteristics Survey (depicted in Figure and Figure ); (ii) a proprietary small business survey with a question on perceptions of the availability of finance that was discontinued at end 2020; and (iii) official bank lending data, which include interest rates and lending by sector and firm size after the dataset was expanded in 2019. Establishing a comprehensive survey in Australia like the European Central Bank and European Commission Survey on Access to Finance of Enterprises would help close the data gap. Likewise, a survey of bank credit conditions could be published, as in many other OECD countries, including Canada, euro member countries, New Zealand, the United Kingdom and the United States (OECD, 2018b).

\section{Fostering greater competition}

In recent years the authorities lowered barriers to entry by creating a "restricted banking licence", broadening usage of the word "bank" to all authorised deposit-taking institutions and increasing the ownership threshold from $15 \%$ to $20 \%$. After two years a restricted licence holder must meet prudential requirements or exit. From 2018 to 2020, APRA granted restricted licences to six Australian-incorporated banks (of which one remains a restricted bank), five branches of foreign banks and one provider of purchased payment facilities. Two more restricted banking licences were issued in July and August 2021. This compares with 10 banking licences (of all types) in the previous decade. However, only two graduated to full licences. In early 2021 , one of these exited and another new entrant was purchased by a major bank. Challenger banks struggle with access to capital, customer acquisition and recruiting staff (APRA, 2020c). APRA plans to raise the bar slightly for gaining a full banking licence (e.g. launching an income-producing product and a deposit product beforehand) to make these banks more sustainable. It could further streamline authorisation and the compliance burden during the initial transition phase as well as devoting more resources to supporting newly accredited banks. Allowing small specialised banks to apply for a restricted licence with lower levels of capital, as in the United Kingdom, could attract more entrants without jeopardising financial stability (Box 3 ).

\section{Box 3. Lessons from the UK experience of reducing barriers to entry in the banking sector}

In 2014 authorities in the United Kingdom implemented reforms to:

- Reduce capital and liquidity requirements for new banks, including providing new banks with regulatory relief for 3-5 years and introducing a "Small Specialist Bank" model to allow niche banks to start up with lower capital requirements. Small Specialist Banks must carry out at least one of three activities, one of which is lending to SMEs.

- Increase the transparency and availability of support prior to and during the authorisation process and reducing information requirements. This also included a more flexible "mobilisation" option for the authorisation process.

A formal evaluation of the reforms found that:

- Lowering barriers to entry positively impacted entry and benefited consumers via better offerings of specialised products.

- There has not yet been a substantial effect on market shares and competition. This may be because of other barriers to expansion such as "sticky" customers.

- A shift from a perceived "black box" around the authorisations process to a clearer simplified process had a positive impact on entry. 
Some UK challenger banks have also benefitted from government financial support (mostly guarantees and public investments) via the British Business Bank.

Source: Baker, R. et al. (2018), "An evaluation of reducing barriers to entry into the UK banking sector", FCA Evaluation Papers, No. 18/3, Financial Conduct Authority, London; OECD (2020), "Recent trends in SME and Entrepreneurship Finance", Chapter 1 in Financing SMEs and Entrepreneurs 2020: An OECD Scoreboard.

The regulatory balance between a level playing field and proportionality affects the ability of smaller banks to compete. Regulatory settings, such as capital requirements, advantage larger banks because they can invest in models to calculate risk weights (under the internal ratings approach), which reduces their costs, and the fixed component of compliance costs is proportionately smaller (Carletti and Smolenska, 2017; PC, 2018). APRA estimated banks using internal ratings models saved AUD1 billion (EUR 0.6 billion) in 2017 (PC, 2018). These advantages are somewhat mitigated by other regulatory measures. Those banks using the internal ratings approach that are "domestic systemically important banks" must hold an additional 1 percentage point of Common Equity Tier 1 capital and, along with the fifth-largest bank, they are subject to a levy of $0.06 \%$ of relevant liabilities. Banks using the internal ratings approach also have a risk weight floor for residential mortgage exposures. Some past regulatory decisions have had anticompetitive effects (PC, 2018). Plans to reduce risk weights for SME lending will more closely align Australia with the Basel standards and may help second-tier lenders using the standardised approach better compete in this market. Likewise, plans to simplify reporting requirements and some capital treatment for smaller banks from 2023 will lower their compliance costs. APRA has also encouraged mutual banks to lower operating costs through undertaking collective initiatives that promote scale efficiency (Byres, 2019). As in some other OECD countries, such as Switzerland, one approach is for smaller financial institutions to share back office services and co-operate in raising capital. There is already an APRAregulated entity (Cuscal Limited) that provides transactional banking, liquidity and capital management to institutions including credit unions, mutual banks and superannuation funds in Australia.

Policymakers can improve the balance of competition in several ways. Until the new capital requirements are in place APRA should consider providing temporary relief on small business lending for banks using the standardised approach. In bringing forward this element of the new capital requirements in isolation, any unintended consequences for other parts of the system should also be evaluated. APRA could also allow banks using the standardised approach to apply to vary risk weights for SME lending based on their loan performance data and sufficiently rigorous risk management, as recommended by the Productivity Commission (2018), with care not to underestimate underlying risk. It could streamline the pathway for accreditation of internal ratings models, as in the United Kingdom. As part of its aim to increase competition in lending, the UK Prudential Regulation Authority changed its application processes for accreditation of internal ratings models to facilitate applications from smaller lenders (PRA, 2018). Australia's financial regulators now all have competition within their mandate and APRA and the ACCC have also undertaken to, inter alia, consult and collaborate in developing policy on overlapping activities. Over time APRA will build expertise in competition matters. The ACCC has been reporting on pricing in mortgage markets annually. This could be extended to annually reporting on competition in retail banking to the Council of Financial Regulators and making policy recommendations.

A market for securitised SME loans could lower funding costs for smaller banks and non-bank lenders and prove attractive for institutional investors. The market for securitised SME loans is small and almost entirely comprised of secured loans, reflecting the structure of SME lending (Department of the Treasury, 2018). The government established the Australian Business Securitisation Fund in 2019 to develop the market by investing in securitised assets and in warehouses backed by loans issued by non-bank lenders and smaller banks. Its activity paused due to the disruption in financial markets due to the pandemic. The first securitisation involving the Fund was launched in early 2021. The issuing bank - a new small businessfocussed bank - intended to use the funds as collateral in repurchase agreements with the RBA to access lower cost funding. 
Other OECD countries' experience suggests that a key challenge will be overcoming the information asymmetries facing investors due to the heterogeneity of SMEs and inadequate credit information (Nassr and Wehinger, 2014). Through the Australian Business Securitisation Fund the Australian Office of Financial Management is supporting the development of a clear track record for the asset class and is also working with industry to help standardise data collection and reporting for SME loans. OECD experience suggests that a centralised data platform will be beneficial for developing the market. Policymakers should facilitate faster implementation, drawing on international experience. Including information on the credit quality of the borrower could also help investors. In France data sharing is a feature of the Euro Secured Notes Issuer Initiative, which is a joint public-private initiative that draws on the Banque de France's credit assessment of SMEs from its database of firms' financial information and banks' internal ratings (Boschmans and Pissareva, 2018). Other countries including Japan also have large databases with SME credit ratings. The fast-moving developments in data and technology discussed below could facilitate a similar service.

\section{Reducing information asymmetries to support lending}

To help improve access to credit, and lower its cost, the government introduced the Personal Property Securities Act in 2009 (which commenced in 2012) and created the Personal Property Securities Register. It covers a range of personal property including intangible assets such as intellectual property. As such, it could be particularly useful for innovative firms with intangible assets and entrepreneurs without housing collateral. In principle the register should also help businesses protect their security interests. Yet, reviews have found that its design was too complex and awareness among businesses is low (ASBFEO, 2021; PMC, 2020; Whittaker, 2015). The independent statutory review of the Act highlighted the need to simplify the Act to generate more predictable outcomes, which would give lenders greater confidence (Whittaker, 2015). The government is considering its response to the 2015 statutory review. It should move ahead with reforms in consultation with stakeholders. A new project aims to improve the website to reduce errors during registration. Streamlining the system, reducing compliance costs and making better use of available technology (including regtech) would help realise its potential. Policymakers should work with key users such as lenders, businesses and accountants to help them understand the register.

Given the growing importance of intangible assets, particularly for high-growth SMEs, and the challenges such firms face in obtaining finance, a number of governments are considering how to address market failures in recognising intangible assets as collateral (Brassel and Boschmans, 2019). Lenders face challenges including valuation, high transaction costs and an uncertain liquidation value in case of default. Australia's Personal Property Securities Register provides a good foundation, by allowing for such assets. Policymakers should also work with lenders to improve valuation of intellectual property and other intangible assets to facilitate their use as collateral. For example, in Japan, the patent office led a two-pillar strategy to reduce market failures associated with lending to SMEs against intellectual property by funding up to 150 independent valuation reports annually and educating smaller regional lenders on how to use evaluation reports to value intellectual property (Brassel and Boschmans, 2019).

The digital revolution in financial services with progress in big data analysis can improve lenders' ability to assess credit risk, lowering screening costs and expanding access to finance. Firms with non-traditional business models, such as young innovative businesses with a high share of intangible assets, will benefit. Information on creditworthiness has been expanded through the transition from negative credit reporting to mandatory comprehensive (positive) credit reporting from 2014 to 2021. Information including open accounts and repayment history will be available to prospective lenders. Research across a range of countries shows that positive credit reporting improves credit risk assessments compared with only negative credit reporting (World Bank, 2019). Because an owner's history helps assess risk, it should benefit small and young businesses. Coverage could be extended to SMEs, as in many countries (Koreen et al., 2018). It would benefit young firms and firms with intangible assets by "thickening" their credit files by including additional information such as loans outstanding and utilities payments. The UK required large 
banks to share SME data with designated credit agencies to improve the reliability of credit scores for use by all lenders (OECD, 2018b). As mentioned above, in France and Japan the public sector produces a credit score. Education campaigns should make individuals, and businesses if extended, aware of how to maintain a good credit score.

Open banking - the first step in Australia's consumer data right - could be transformative. Initial benefits are likely to include stronger competition by allowing comparison websites to provide tailored information on product offerings and improved financial record-keeping to ease credit access through fintech companies that provide financial management tools. Its rollout is scheduled to be completed by February 2022 (Box 4; Figure 18). The design draws on lessons from elsewhere, with interoperability assured by government-determined standards and a focus on securing trust. To date the launch has been low-key as the industry adjusts. There are seven active accredited data recipients and not all data holders are fully compliant with their data access obligations. After these wrinkles are ironed out government and business groups should raise awareness amongst consumers. Other countries' experiences also suggest awareness is important (OECD, 2020e). Because customers' barriers to switching providers are high, the scheme should ultimately allow a third party to initiate actions such as making payments and opening or closing an account with the customer's consent (known as "write access" or "action initiation"; Farrell, 2020). However, it is important that such changes are accompanied by appropriate protections. In the United Kingdom, where open banking was launched in 2018, the share of small businesses switching current account providers has increased from 4\% in 2016 to 10\% in 2020 (OBIE, 2020).

\section{Box 4. Australia's Consumer Data Right and open banking}

Australia's consumer data right aims to given consumers control over their own data, ultimately delivering more choice and better services. It launched in the banking sector in 2020 and is being implemented in phases until February 2022 (Figure ). Energy has been designated as the next sector, followed by telecommunications. Other sectors will follow, as designated by the responsible Minister.

Open banking gives customers greater access to, and control over, the data their banks hold on them. Key design features of the system include:

- "Accredited data recipients" are approved to receive data from a "data holder" (bank) after a consumer's request. Recipients then use it for the requested purpose.

- Consent may be withdrawn at any time and data can be deleted on request.

- "Accredited intermediaries" may collect data on behalf of third-party data recipients after a consumer's consent. In practice this means an accredited business (e.g. a fintech) can use the IT infrastructure and software of an accredited intermediary.

- There is "read-only" access, that is, data sharing. By contrast the UK and EU approaches also allow payments initiation (a form of "write access").

- Banks must share data in an interoperable format set by the Data Standards Body. Data standardisation is left to the private sector in some other regimes, including in Europe. In the United Kingdom banks were tasked with creating, adopting and maintaining common standards.

Proposed amendments to the rules aim to broaden participation, for instance by introducing a sponsored tier of accreditation (by an unrestricted accredited sponsor) and allowing consumers to share their data with professional advisers such as accountants.

The Treasury has overarching responsibility for the Consumer Data Right (initially it was the ACCC). The ACCC and Office of the Australian Information Commissioner are responsible for enforcing consumer data rights and protections.

As at beginning September 202131 companies were able to share data ("data holders"), almost all of which are banks. In addition, some of these banks offer products under additional brands which are 
also covered. There were 13 "data recipients" accredited to offer services under the CDR, including two banks. Seven of these services were active.

Source: OECD (2020). "Open Banking", chapter 2 in OECD (2020), Financial Markets, Insurance and Pensions: Digital Technologies and Finance, www.oecd.org/finance/financial-markets-insurance-and-pensions-report.htm ; Farrell, S. (2020), Inquiry into Future Directions for the Consumer Data Right; www.cdr.gov.au

Figure 18. Open banking is being phased in

\begin{tabular}{|c|c|c|c|c|c|c|}
\hline July 2020 & $\begin{array}{c}\text { November } \\
2020\end{array}$ & $\begin{array}{c}\text { February } \\
2021\end{array}$ & & July 2021 & $\begin{array}{c}\text { November } \\
2021\end{array}$ & $\begin{array}{c}\text { February } \\
2022\end{array}$ \\
\hline $\begin{array}{l}\text { - Major banks } \\
\text { - Consumer accounts }\end{array}$ & $\begin{array}{l}\text { - Major banks } \\
\text { - Consumer loans }\end{array}$ & $\begin{array}{l}\text { - Major banks } \\
\text { - Other accounts } \\
\text { including business } \\
\text { accounts and loans }\end{array}$ & $\begin{array}{l}\text { - Reciprocal data } \\
\text { holders } \\
\text { - Consumer accounts }\end{array}$ & $\begin{array}{l}\text { - Other banks } \\
\text { - Consumer accounts } \\
\text { - Reciprocal data } \\
\text { holders } \\
\text { - All other data }\end{array}$ & $\begin{array}{l}\text { - Other banks } \\
\text { s } \cdot \text { Consumer loans }\end{array}$ & $\begin{array}{l}\text { - Other banks } \\
\text { - Other accounts } \\
\text { including business } \\
\text { accounts and loans }\end{array}$ \\
\hline
\end{tabular}

Source: Australian Government (2020), Consumer Data Right: Phasing, available at www.cdr.gov.au/rollout

StatLink त्ञाI

Open banking and digitalisation more broadly promise to increase contestability of banking through nonbanks providing some banking services (although the long-run effects will depend on regulation) (OECD, 2020a). Fintechs may drive down the rents in financial services (OECD, 2020e). Some payment services providers have begun offering credit to their customers. The insights these firms gain from processing payments can assist with credit risk assessment. Buy-now, pay-later products are being offered to SMEs and some accounting software companies are partnering with fintechs to offer invoice financing. One digital bank is offering "banking as a service" to allow its non-bank customers to offer banking services.

To support fintech entrants ASIC established an Innovation Hub, which provides support services, and a regulatory sandbox. In 2020 the sandbox was broadened and the maximum duration lengthened to two years. A UK-Australia Fintech Bridge established in 2018 aims to reduce regulatory barriers to entry between the two markets. In 2019 a Senate committee on financial and regulatory technology was tasked with examining the opportunities and barriers presented by these new technologies. Its recommendations in two interim reports span tax policy, regulatory settings, access to capital, skills, the consumer data right and blockchain (Select Committee, 2021, 2020). Many barriers, such as access to finance and to skilled workers, are common to innovative start-ups. In that context, the Committee has recommended adjusting public equity regulations to make it easier for company founders to scale back their investment (such as in the United States, with sufficient safeguards) and to increase retail investor participation. It also finds that uncertainty around eligibility of software for research and development tax incentives limits their effectiveness; this should be addressed. Shifting from annual to quarterly payment of rebates, as recommended, would better buttress firms' cash flow. Increasing visibility of the regulatory sandbox and Fintech Bridge may increase take-up. In May 2021 the government announced two new visas for highskilled workers and plans to modernise the tax treatment of employee share schemes.

Regulators are also grappling with how to maintain competitive dynamics after entry. Incumbent banks often partner with new entrants, acquire them or invest in them (Lumpkin and Schich, 2020). Acquisition can provide an incumbent with the new technology more economically than internal investment and can improve overall efficiency through more widespread distribution, for example. But it may also stifle competition. The ACCC has so far allowed such transactions but warned that it will scrutinise takeovers by any of the four major banks more closely than smaller banks (ACCC, 2021). In several countries competition agencies have adjusted merger notification thresholds to allow them to investigate cases where an incumbent might purchase a start-up to limit potential competition (OECD, 2020e). Appropriate 
regulations for big tech are particularly challenging (OECD, 2020a, 2020e). Authorities should also continue to strive for technologically-neutral regulations and minimise opportunities for regulatory arbitrage. For instance, because of the structure of their contracts some credit-like services are not regulated as credit. Likewise, less data will be available to measure their growth.

\section{Broadening sources of finance beyond banks}

There has been a trend across OECD countries since the global financial crisis to develop alternatives to bank lending for small and young firms. However opportunities for these firms to access non-intermediated debt markets are likely to be limited. This is especially the case in Australia where the corporate bond market is comparatively small (which is currently the subject of a parliamentary committee inquiry). Consequently there has been more focus on equity instruments in practice (Boschmans and Pissareva, 2018). Moreover, equity finance can better suit some young firms without collateral or a track record of good performance, and firms planning intangible investments.

Empirical research links equity financing to innovative activity, particularly in high-tech sectors (Brown et al., 2012; Hsu et al., 2014). Developing public equity and venture capital markets can fuel productivity growth by financing intangible capital (Demmou et al., 2019). Venture capital is empirically associated with faster growth of young firms and investment in knowledge-based capital (Calvino et al, 2015; Andrews et al., 2014). Research from the United States suggests that early-stage engagement yields the greatest productivity gains (Heil, 2017). However, across countries, the obstacles to finance are largest for highrisk, high-return equity-type instruments that best serve young firms and innovative and fast-growing SMEs (Boschmans and Pissareva, 2018). On the demand side, small and young firms can be reluctant to relinquish control. Further hurdles to overcome include valuing the company, fixed costs of raising equity and the supply of investors (Nassr and Wehinger, 2016). Opportunities to improve access to public equity, venture capital and crowdfunding are discussed below.

Public equity markets offer numerous benefits beyond the initial capital raising, including access to further capital and increased creditworthiness, transparency, visibility and improved corporate governance induced by listing (Nassr and Wehinger, 2016). There are four exchanges in Australia: the Australian Securities Exchange (ASX - the main stock exchange), the National Stock Exchange, the Sydney Stock Exchange and Chi-X Australia (which is for trading only). The overall level of capitalisation and liquidity on the ASX compares well to other countries (Figure 19). Liquidity declines with company size, as expected. The amount of capital raised through initial public offerings (IPOs) compares well, though it is small relative to credit: in 2018-2020 IPOs by non-financial companies amounted to around $0.2 \%$ of GDP on average (Figure 20). Secondary public offerings have been much larger than IPOs and particularly large compared to other markets. Australia's IPOs tend to be smaller than in other countries: around $80 \%$ of listings have been below AUD50 million compared to around 50\% globally below USD50 million (AUD68 million) (Figure 21, Panel A; Nassr and Wehinger, 2016). Listings have been dominated by the resources sector, reflecting the high share of resources companies in the overall market (over one-quarter of capitalisation) (Figure 21, Panel B). However, there are signs of greater diversification in recent years. 
Figure 19. The stock market is sizeable and liquid

\section{A. Market capitalisation}

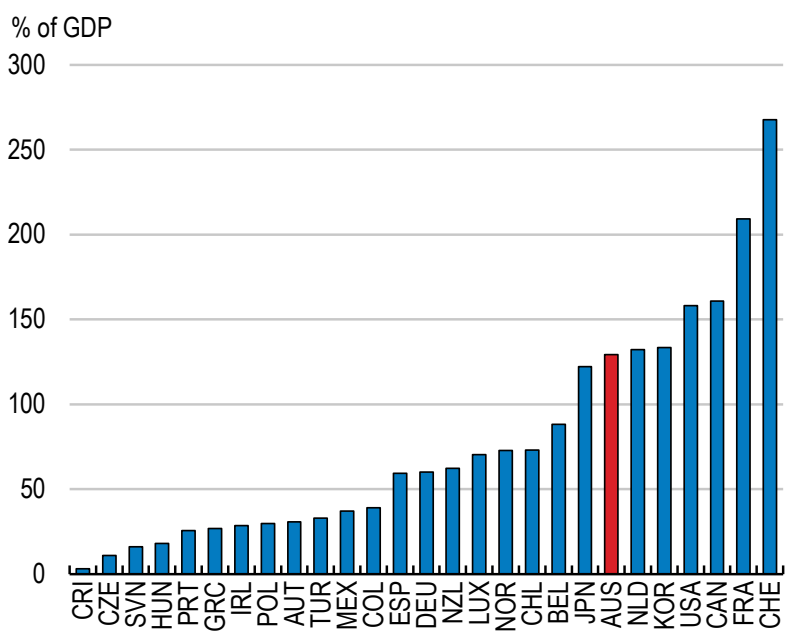

\section{B. Turnover}

$\%$ of market capitalisation

300

250

200

150

100

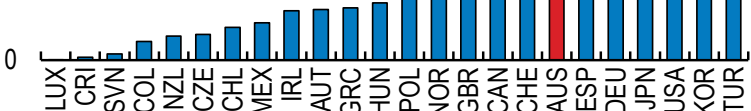

Note: Market capitalisation is at 2020. Turnover is the average over 2018-20.

Source: World Bank World Development Indicators database.

StatLink त्ञाज https://stat.link/7clfmp

Figure 20. Public equity raising has been comparatively strong

Non-financial companies, 2018-20 average

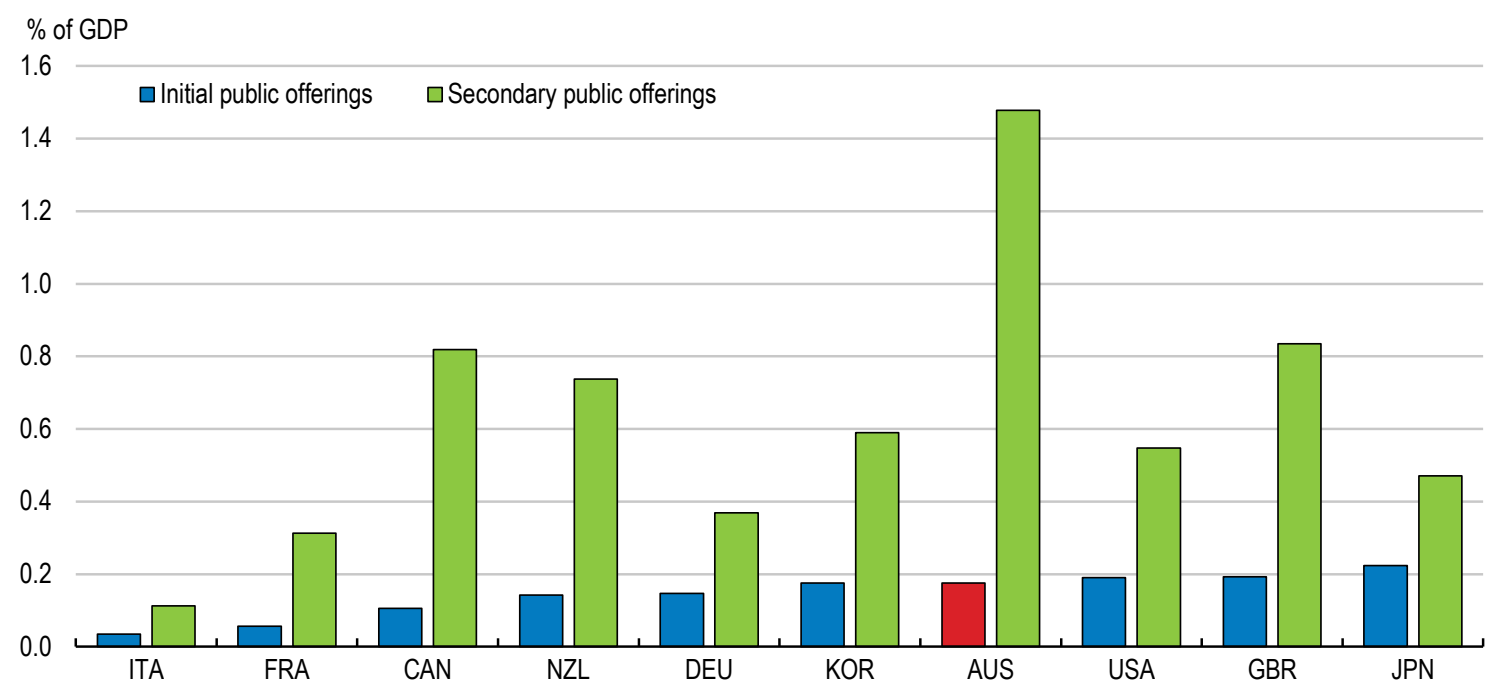

Note: Countries are ordered according to size of initial public offerings.

Source: OECD Capital Market Series dataset; OECD, Economic Outlook database.

StatLink त्ञाIst https://stat.link/z86n7y 
Many other OECD countries have established junior boards and growth segments in public markets to ease capital-raising for smaller firms following the 2008-09 financial crisis. They have also enhanced flexibility and proportionality in disclosure requirements (OECD, 2018c). Junior boards and growth segments typically offer more flexible listing criteria, simplified disclosure and lower costs (Nassr and Wehinger, 2016). By contrast, the ASX has a one-size-fits-all approach. However, it promotes awareness of listed smaller companies through its Equity Research Scheme that subsidises broker reports on eligible companies and a bi-annual small-to-mid caps investor conference. Older research suggests that, despite the one-size-fits-all structure, the ASX was relatively hospitable for small listings because of larger tick sizes (i.e. the minimum price change between different bid and offer prices; Weild et al., 2013). The National Stock Exchange (NSX) and Sydney Stock Exchange have simplified listing rules, including lower thresholds, to attract smaller companies. The NSX is larger but nevertheless has only around 50 listings, low liquidity (falling to an average of two trades a day in 2019 but increasing since), past governance concerns and little visibility (Dwyer and Kotey, 2015; ASIC, 2017). Consultations in 2012 and 2015 found no support for a junior board on the ASX (ASX, 2012; PC, 2015). Since then, however, the ASX has raised listing thresholds and has taken a more stringent approach to reverse takeovers (known as back-door listings), which have previously been used by small companies to list with less paperwork.

The authorities should again revisit the idea of introducing a junior board, in consultation with stakeholders such as investors, private capital and business representatives, given the spillover effects from equity markets and alternative financing options for growth prospects of start-ups and SMEs. Although listing requirements on the ASX are lower than some main exchanges in other countries, some requirements appear higher than the junior boards. Different models that have been adopted abroad should be considered. For instance, the London Stock Exchange's junior exchange (AIM) has minimal listing requirements and disclosures but requires firms to work with an approved Nominated Advisor ("Nomad") which, inter alia, undertakes due diligence and provides guidance (OECD, 2015a). Australia could consider following the UK, German and US approach of a growth segment in the main market, which also has easier listing rules but targets a different type of firm. A further possibility is to develop one or both of the existing exchanges that have simplified rules and better incorporate them into the overall equity ecosystem. This would require working with all stakeholders to build trust, visibility and liquidity to gain buy-in from investors.

Regulators and the ASX should also explore ways of introducing greater flexibility and proportionality in existing listing and disclosure requirements, while preserving market integrity. This should target aspects of laws and regulations that particularly affect young companies and new business models. An alternative to a specific segment is the US approach to "Emerging Growth Companies", whereby companies are allowed regulatory relief during a period of transitioning from a private to public company that can last five years (OECD, 2018c). Investors are informed in the prospectus that the company will face simplified disclosure requirements. 
Figure 21. Small IPOs are relatively common

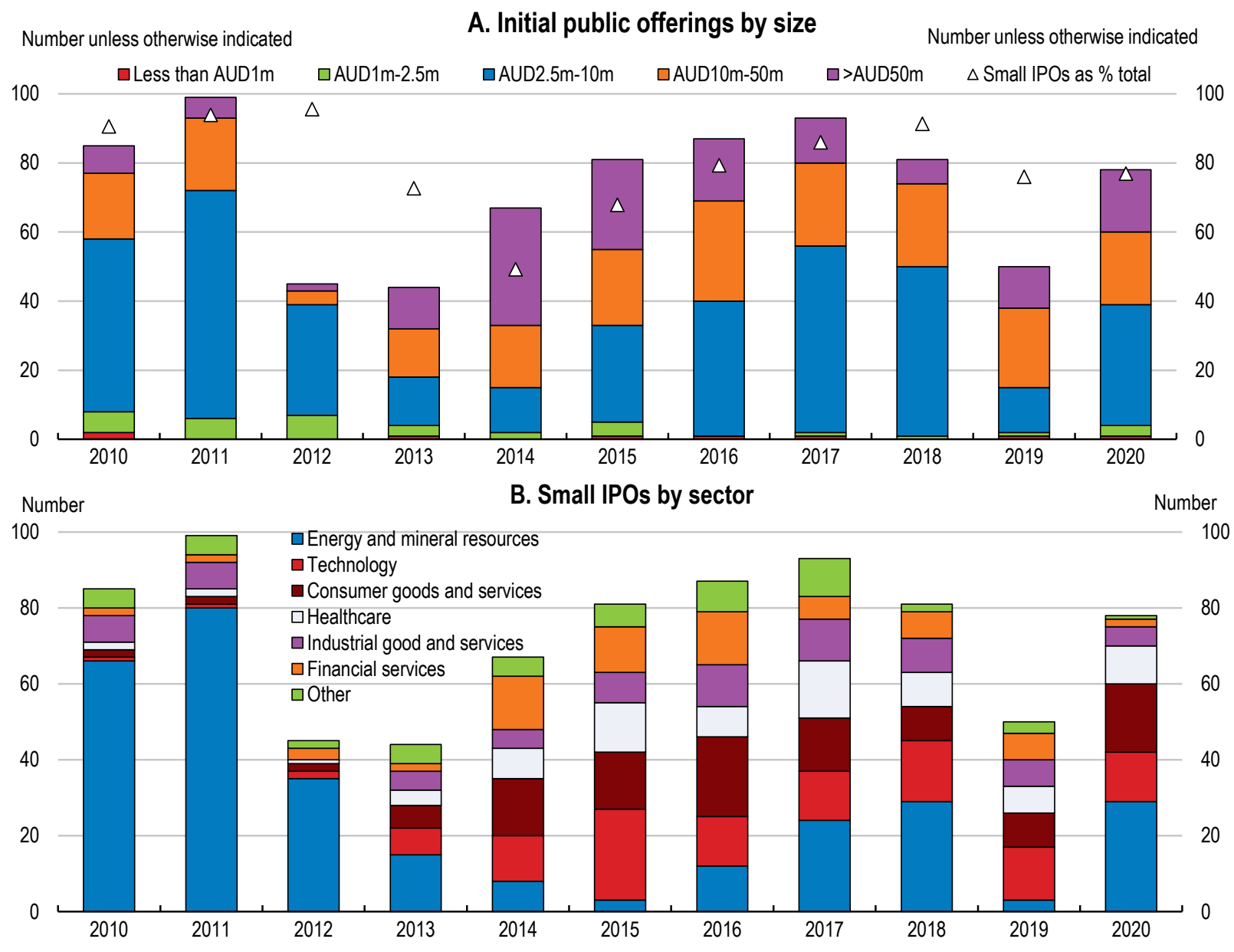

Note: Data are shown by the listing date. Small IPOs are defined here as those below AUD50 million. Real estate investment trusts, collective investments, investment holding companies and unit trusts are excluded.

Source: Refinitiv; OECD

StatLink ज्ञात्य https://stat.link/if8j90

Australia's venture capital market is still recovering from the global financial crisis (Figure 22, Panel A). Seed and early-stage capital is especially low (Figure 22, Panel B). As in many OECD countries, there are tax incentives to attract capital: Early-stage Venture Capital Limited Partnerships and Venture Capital Limited Partnerships. Both provide tax benefits, including income tax exemptions on some income and gains. To avoid double taxation, the partnership does not pay tax but income and gains flow through to investors ("flow-through tax treatment"). There is also an "Early Stage Innovation Company" tax incentive that provides domestic investors in qualifying companies with a non-refundable income tax offset based on their investment and capital gains tax relief. Usage of the early-stage partnerships approximately doubled in 2016-17 after reforms made them more attractive. Most of the growth has been in investment in information, media and telecommunications, health care and services businesses. However, they are small relative to the market: at June 2020, they were associated with AUD2 billion in committed capital compared to AUD12 billion for the later stage partnerships and investments totalled AUD0.4 billion. The two incentives are currently undergoing a statutory review. The Productivity Commission has previously recommended that the Venture Capital Limited Partnerships be closed but the early-stage partnerships be continued and evaluated (PC, 2015). 
Figure 22. Venture capital is low and has not recovered since the global financial crisis

\section{A. Venture capital over time}

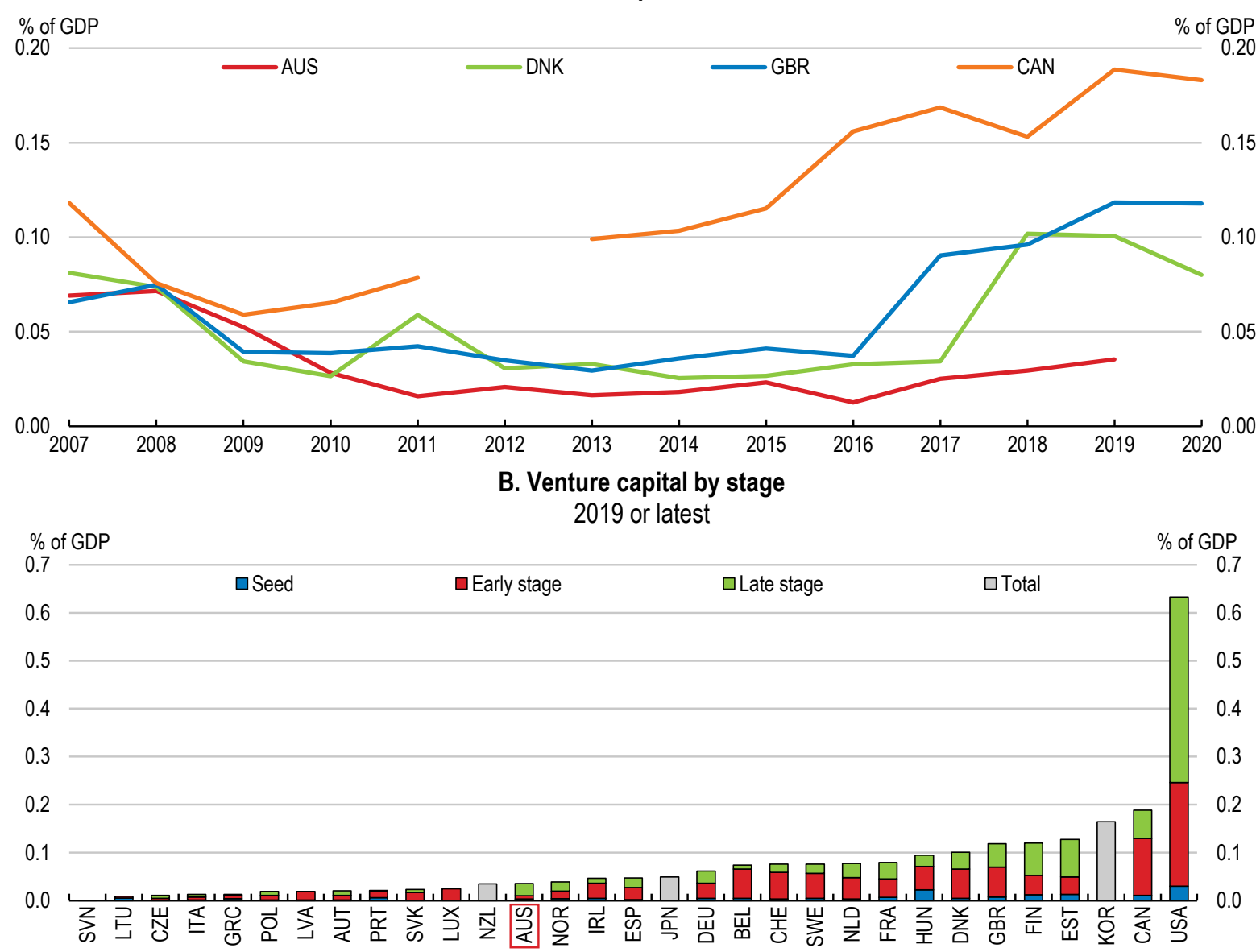

Note: A breakdown of venture capital investment is not available for Japan, Korea or New Zealand.

Source: OECD, Venture Capital Investments database

StatLink הत्ञाs https://stat.link/7f1jdm

There are strong grounds for government support given the evidence linking venture capital with innovation and productivity growth, combined with market failures relating to a lack of information affecting young, innovative firms. In the decade since the financial crisis many OECD countries, including the United Kingdom, Canada and Denmark, have established co-investment funds to leverage private sector capital and help build a stronger early-stage venture capital market (OECD, 2019a). Co-investment may mean government funds are better disciplined by private capital. Evidence from Europe, where the market is less developed than in the United States, suggests that government co-investment can augment, or crowd in, private investment (Kraemer-Eis et al., 2016; Brander et al, 2015). Nonetheless, it should be noted that government investment in venture capital has had mixed results in many countries, often when such structures are in their infancy and the model is still being tailored to local conditions (Murray, 2021). Earlystage financing via the European Investment Fund (which manages funds-of-funds that invest in majority private-sector funds) has been found to boost firm performance (Pavlova and Signore, 2019). Governmentcontrolled venture capital tends to be different in character, with recent OECD research suggesting it is most successful when targeting new technology-based firms linked to academic research (Dechezleprêtre and Fadic, forthcoming). In Australia, both types of funding are small; for example OECD data suggest that government venture capital funds represent just $1 \%$ of total venture capital investment, compared to the OECD median of $4 \%$. 
The government has been building the venture capital eco-system. As part of the National Innovation and Science Agenda it created two industry-specific, government-led co-investment funds: a AUD500 million Biomedical Translation Fund (AUD250 million is public money) and a AUD240 million CSIRO Innovation Fund (AUD100 million is public money). The CSIRO Innovation Fund attracted more investment than anticipated in its first year, including from superannuation funds, pointing to its potential. In 2020 the government launched the AUD540 million Australian Business Growth Fund with AUD100 million of public funds and the remainder from six banks (which receive favourable capital treatment on their investment). The fund aims to ease financing constraints for SMEs through equity investment of up to AUD15 million and up to a $49 \%$ stake. However, its focus is on SMEs with a track record, rather than riskier high-growth start-ups.

A deeper venture capital sector may be beneficial in attracting more conservative investors such as superannuation funds in the longer term. Policymakers should evaluate existing support programmes and work with stakeholders to identify potential interventions to support the development of venture capital markets. One option is for the government to complement existing mechanisms with the development of a private-led early-stage co-investment fund. Such a fund has been called for by the venture capital industry, suggesting that it would not displace private capital. Many other countries, such as Denmark and Canada, now have co-investment via funds-of-funds as part of their overall plan (Table 6; OECD, 2020d). Fundsof-funds provide additional diversification and further distance the government from investment decisions. However they add additional fees, thereby lowering returns. Private sector concerns about low returns and high fees were found to have slowed the implementation of Canada's Venture Capital Action Plan (OAG, 2016), highlighting the importance of developing any initiatives in conjunction with other actors in the venture capital ecosystem.

\section{Table 6. Examples of government venture capital initiatives}

\begin{tabular}{l|l|l}
\hline Country & \multicolumn{1}{|c|}{ Initiative } & \multicolumn{1}{c}{ Description } \\
\hline Canada & $\begin{array}{l}\text { Venture Capital Action } \\
\text { Plan }\end{array}$ & $\begin{array}{l}\text { The plan was announced in 2013 with CAD400 million to reinvigorate the sector. CAD340 million was } \\
\text { used to recapitalise four large scale private sector-led funds of funds. These funds raised CAD904 } \\
\text { million from private investors. At December 2019 7\% of commitments were seed and 50\% were early } \\
\text { venture. }\end{array}$ \\
\hline Denmark & Danish Growth Fund & $\begin{array}{l}\text { The Danish Growth Fund was created in } 1992 \text { but venture and growth capital has expanded } \\
\text { dramatically since 2016. Its instruments include: direct investments, fund investments, fund-of-fund } \\
\text { investments through Danish Growth Capital and syndication loans. The objective is to address } \\
\text { underinvestment in innovative ventures. Danish Growth Capital is highly independent and all } \\
\text { investments are made on private terms with private investors. }\end{array}$ \\
\hline
\end{tabular}

Source: OECD (2020), Financing SMEs and Entrepreneurs 2020: An OECD Scoreboard; Government of Canada www.ic.gc.ca/eic/site/061.nsf/eng/03129.html (accessed 6 April 2021).

Potential barriers to investment by superannuation funds and foreign investors should be investigated. The market disruptions in 2020 and early withdrawals of superannuation risk incentivising funds to keep more money in liquid assets. Some industry participants have expressed concerns that the penalties associated with new performance benchmarks (which aim to improve fund performance through greater transparency and accountability) could unintentionally lead to more conservative strategies that replicate benchmarks. At the same time, others highlight that the new rules should result in lower superannuation fees for account holders and may improve superannuation fund performance overall (Coates, 2021). Funds that underperform their benchmark (which incorporates asset allocation) by $0.5 \%$ in two consecutive years will be closed to new members until performance improves (and labelled as underperforming). The superannuation industry has proposed a wider margin and a trial period. While steps to address underperformance are warranted, the changes should be evaluated once they have had time to come into effect, in relation to any unintended consequences that undermine the potential of superannuation as a source of patient capital as well as the net returns received by fund holders. Other potential regulatory 
barriers should also be explored with industry. Complex foreign investment rules may dissuade foreign investors (Allens, 2021), who typically contribute expertise in addition to funding (Bradley et al., 2019). As such, the potential for removing barriers to their investment should be explored to further develop the venture capital eco-system. Greater transparency around returns could provide superannuation funds and foreign investors alike with greater confidence (ibid.).

Crowdsourcing equity is another potential source of seed or early-stage financing for start-ups. It is part of the fast-growing online alternative finance market, but is only a relatively small segment, accounting for $3 \%$ of global online alternative finance (OECD, 2020d). Australia's online alternative finance has grown rapidly, with around three-quarters representing business finance, but at AUD858 million, this was only equivalent to $1 \%$ of SME lending in 2018 (Figure 23; CCAF, 2020). In 2017 the government created a legal framework for "crowd-sourced funding". It provides investor protections through features such as requiring intermediaries to hold an Australian Financial Services licence and limiting annual investments by retail investors. ASIC has published guidance notes for intermediaries and companies and a template offer document. In 2020 AUD30 million was raised from 49 deals (Birchal, 2021). The typical investment since inception is small at AUD1 300 (ibid). The market is still small relative to other countries. It is still early to assess the potential of crowd-funding, with factors such as exit possibilities likely to influence its success (Nassr and Wehinger, 2016). ASIC should maintain its constructive approach to ensure regulatory settings evolve appropriately over time.

\section{Figure 23. Alternative finance is still in its infancy}

Online alternative finance

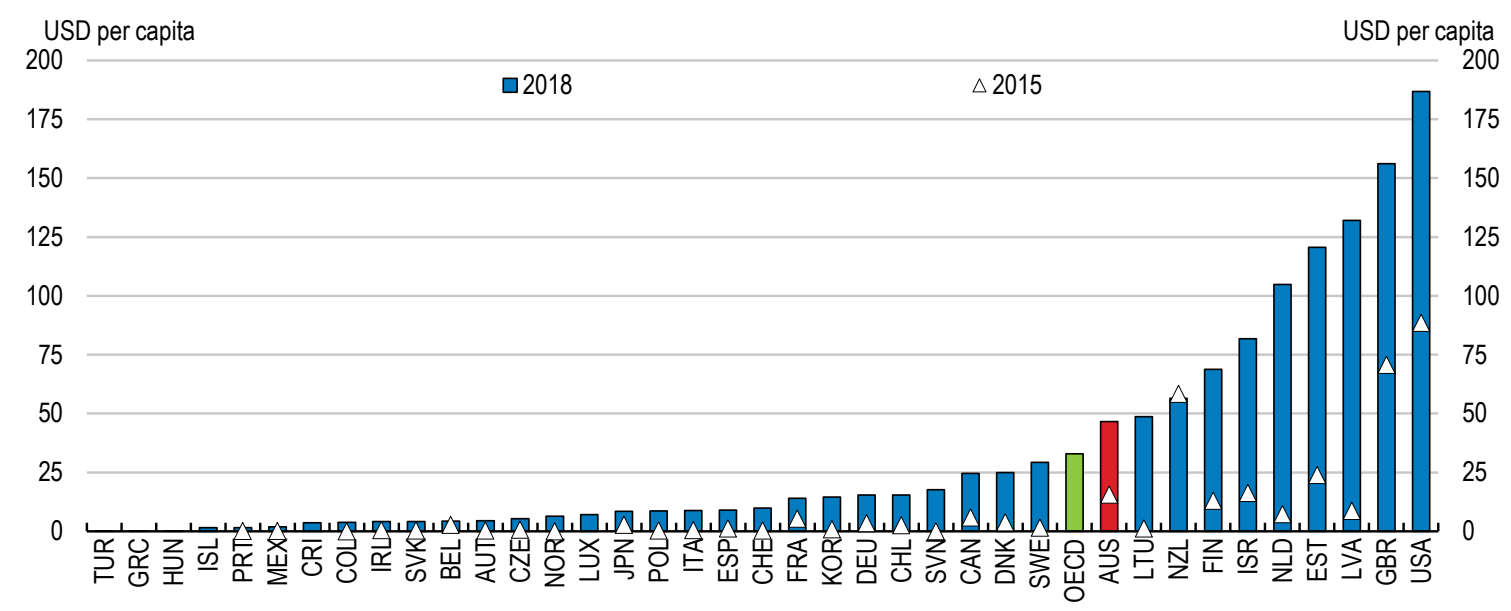

Note: 2015 data for Austria, Belgium, Czech Republic, Denmark, Estonia, Ireland, Lithuania, Portugal, Slovakia, Slovenia and Switzerland are for credit only.

Source: Cambridge Centre for Alternative Finance (2020), The Global Alternative Finance Benchmarking Report; G. Cornelli et al. (2020), "Fintech and big tech credit: a new database", BIS Working Paper, No. 887; OECD, Population Statistics database.

StatLink הत्ञाs https://stat.link/tf194j

\section{Supporting the green transition}

The financial sector can directly and indirectly support a climate-resilient and sustainable recovery. Investment is needed to meet climate change mitigation commitments as well as for adaptation. In 2017 the OECD estimated that to limit warming to 2 degrees by 2050 global infrastructure investment would need to be $10 \%$ higher than the baseline (OECD, 2017b). Modelling for Australia points to significant nearterm opportunities associated with meeting the limit in carbon sequestration, manufacturing and transport (IGCC, 2020). Investment is also needed for adaptation. For example, investment of up to AUD3.5 billion 
$(0.2 \%$ of 2020 GDP) annually may be needed for natural disaster resilience to avoid spending AUD39 billion annually on ex-post repair by 2050 (Summerhayes, 2020). But externalities associated with these investments mean that new processes, products and technology will be underdeveloped, particularly in the absence of carbon pricing. Meanwhile key climate-related risks - damaged or stranded assets, a disorderly transition, and litigation - remain. There have already been high-profile court cases involving a bank and a superannuation fund related to their disclosure and management of climate-related risks. Recent legal opinions have highlighted the growing legal responsibilities for company directors and superannuation trustees (Hutley and Davis, 2019, 2021; Hutley and Mack, 2021). With Australia's economy being the second-most carbon-intensive in the OECD, the importance of an orderly transition cannot be overstated.

\section{Enhancing risk disclosure}

Widespread early and science-based disclosure can be a powerful tool in improving the efficiency of private financial flows and supporting a smooth transition to a low-carbon and climate-resilient economy for the financial and non-financial sector alike (OECD, 2021b; OECD, 2017b; Boissinot et al., 2016). This is particularly so for Australia given the scale of the challenge and policy uncertainty documented in previous Surveys. The Australian equity market is comparatively carbon-emissions intensive, with half of the estimated emissions intensity from the materials sector, which is one-fifth of the S\&P/ASX200 index (MSCI, 2021; Gocher et al., 2021).

Australia has robust periodic and continuous disclosure requirements for material risks under the Corporations Act. While disclosure of climate-related risks has been increasing under this framework, it is mixed. In $2020,78 \%$ of the top 100 listed companies clearly acknowledged climate change as a business risk in their reporting but only $58 \%$ used the Task Force on Climate-related Financial Disclosures framework (encouraged by ASIC) and one-third of them included climate risk in their reporting (KPMG, 2020). Nonetheless, all of these figures rose significantly from 2017 and they compare fairly well against other countries (ibid.) However, Australia's large listed companies are lagging international peers in using scenario analysis in reporting and setting science-based carbon targets (such as consistency with the Paris Agreement; ibid). ASIC's 2017 survey of listed companies showed that, as in most countries, small companies lag behind larger companies considerably in including "climate change content" in annual reports (ASIC, 2018a). There is also dispersion within the financial sector: a 2018 survey by APRA revealed that a majority - but, not all - banks considered climate-related financial risks as part of their risk management frameworks (APRA, 2019). Varying take-up of disclosure hampers financial institutions' and investors' ability to compare risks across businesses and sectors.

A key element in achieving greater and more effective disclosure will be consistent and comparable international standards and quality data to support such disclosure. Australian regulators are active in international working groups and aim to ensure that Australian developments in this area are in line with international standards. Over 2016-19 Australian regulators strengthened calls for better disclosure through the existing legal framework, notably the risk management and disclosure requirements for listed companies under the Corporations Act, regulatory requirements for prospectuses, and through prudential reporting for supervised financial institutions. During 2019 they strengthened their expectations, signalling that the Task Force on Climate-related Financial Disclosures recommendations are a useful way of reporting, and that they would be increasing scrutiny over companies within their remit. ASIC has published high-level guidelines for company directors. In response to requests from industry. APRA is preparing a prudential practice guide covering governance, strategy, risk management, scenario analysis and disclosure of climate-related financial risk. APRA released a draft for consultation and plans to finalise it by end 2021. To fill data gaps and build capability, APRA is also co-ordinating a climate vulnerability assessment with the largest banks, RBA and ASIC. The exercise aims to leverage international experience and banks' experience to date. It includes scenarios and quantification of physical and transition risks on 
bank balance sheets and qualitative assessments of market, liquidity and operational risks (APRA, 2021, 2020d). This could accelerate the take-up of scenario analysis in disclosures by companies.

Recognising growing risks and international momentum, the financial services industry formed two initiatives to co-ordinate its approach to measuring and reporting climate risks. Institutions created the "Climate Measurement Standards Initiative" to establish how to interpret the Task Force on Climate-related Financial Disclosures' recommendations in an Australian context and produce voluntary standards that will lead to consistent and comparable reporting between insurers, banks and asset owners (CSMI, 2020). In 2020 the Initiative published draft scientific scenario specifications and financial disclosure guidelines for scenario analysis of physical risks. Transition risks, which could be sizeable given Australia's economic structure, are on the agenda but not imminent. The second initiative is the Australian Sustainable Finance Initiative, created in recognition of the role of the financial system in: managing shocks like climate change; improving risk management and financial performance by considering ESG risks and opportunities; aligning with consumer expectations; and enhancing the financial system's competitiveness (Herd et al., 2018). In 2020 the Initiative published a Sustainable Finance Roadmap, drawing on technical advice from experts (ASFI, 2020).

Financial institutions have also taken concrete action to reduce their exposures to climate-related risks, partly due to growing pressure from shareholders and investors. For instance, nine superannuation funds managing a combined AUD500 billion (EUR 310 billion) in funds have divested, or begun divesting in one case, from thermal coal mining companies (Market Forces, 2021). The largest banks have announced plans to limit their exposures to fossil-fuel intensive companies, to varying degrees, through a combination of caps on new customers' exposures, divestments and working with existing customers to reduce their emissions. For instance, each intends to have no exposure to thermal coal mining by 2030 or 2035 . In 2019 the four largest banks lent a combined AUD7.6 billion (EUR4.7 billion) to fossil fuel projects (Market Forces, 2020). There is also a risk that market valuations move faster than assumed. While the transition plans can in principle smooth the adjustment path for affected borrowers and the economy, assessing and monitoring these plans will be a challenge for supervisors and banks alike.

Australia should prepare a roadmap for improving the consistency, comparability and quality of reporting of climate-related disclosures within its legal framework. Disclosures should be aligned with recommendations of the Task Force on Climate-related Financial Disclosures (Box 5). This would provide certainty to the private sector and assure more uniform progress. Such disclosures can also include opportunities, as well as risks. Given the progress already made and growing legal risks, it should cover listed companies and the financial sector. It could also cover large unlisted companies as in the United Kingdom. Such a roadmap should be proportionate in its requirements to avoid overburdening newly-listed and small companies. Disclosure by smaller institutions and non-bank lenders should be proportionate but assure a level-playing field. A roadmap would help co-ordinate efforts of all stakeholders to improve the quality of disclosure, including that it is verifiable against science-based targets as recommended in OECD (2021b). Accordingly, regulators should work with stakeholders to develop capacity and understanding. Meaningful disclosure will assist banks and fund managers to better manage their own transition risk, facilitate a better allocation of capital and reduce the risk of a disorderly transition. Sharing data and models could alleviate some of the compliance burden. The Reserve Bank of Australia could also consider reporting on its own climate-related risks as the Bank of England recently did. 


\section{Box 5. The Task Force on Climate-related Financial Disclosures}

The Task Force was established by the Financial Stability Board "to develop consistent climate-related financial risk disclosures for use by companies, banks, and investors in providing information to stakeholders". In 2017 it published 11 voluntary recommendations grouped into four areas:

- Governance: Disclose the company's governance around climate-related risks and opportunities.

- Strategy: Disclose the actual and potential impacts of climate-related risks and opportunities on the organisation's businesses, strategy, and financial planning where such information is material

- Risk management: Disclose how the organisation identifies, assesses, and manages climaterelated risks.

- Metrics and targets: Disclose the metrics and targets used to assess and manage relevant climate-related risks and opportunities where such information is material.

There is supplementary guidance for specific sectors, including banks, insurance companies, and asset managers.

An increasing number of companies have been supporting the Task Force and adopting its recommendations, as are governments. For instance:

- New Zealand's government has published draft legislation to introduce mandatory Task Forcealigned disclosure of climate-related risks for banks, investment schemes, insurers, and government-owned financial institutions with assets or assets under management above NZD1 billion and all companies with equity or debt listed on the national stock exchange.

- The United Kingdom has published a roadmap towards mandatory, Task Force-aligned disclosures across the non-financial and financial sectors of the economy by 2025 .

- The Swiss government announced its support for the Task Force and its intention to make the recommendations mandatory for companies across all sectors of the economy. Disclosure will be mandatory for large banks and insurers from July 2022 and large Swiss firms from 2024.

- The European Commission's Guidelines on Reporting Climate-related Information for companies incorporate the Task Force recommendations.

- France's Energy and Climate law has required non-bank financial institutions to disclose climate-related risks in line with Task Force recommendations since 2016. Listed companies are also subject to mandatory carbon-related disclosures. From 2022, information related to biodiversity-related risks must be disclosed.

In addition, in March 2021 the International Financial Reporting Standards Foundation announced that it will establish a new board for setting sustainability reporting standards, building on existing initiatives such as the Task Force's framework.

In Australia:

- The Australian Sustainable Finance Initiative recommended that financial institutions with revenue above AUD100 million and listed companies, beginning with the 300 largest companies, be required to adopt Task Force-aligned reporting on an "if not, why not" basis by 2023.

- In 2020 the ASX Governing Council encouraged listed companies to use the Task Force framework and recommendations for evaluating and reporting on climate risks. 
- In 2021 three investor groups released a proposed plan to expand mandatory financial disclosure on climate risks. Coverage would begin with ASX300 and large unlisted businesses, and extend to all major financial institutions and companies by 2024.

Source: Australian Sustainable Finance Initiative (2020), Australian Sustainable Finance Roadmap: a Plan for Aligning Australia's Financial System with a Sustainable, Resilient and Prosperous Future for all Australians; TCFD Knowledge Hub, https://live-tcfdhub.pantheonsite.io/.

The financial stability risks associated with Australia's carbon-intensive economy have been a key focus of regulators. The forthcoming vulnerability tests will help financial institutions and regulators alike to better understand risks and standardise measurement. They are informed by the scenarios developed by the Network for Greening the Financial System, which the RBA joined in 2018. The assessments will cover physical risks, including extreme weather events, and transition risks caused by climate change under two scenarios. These will apply to banks' residential mortgage and business lending portfolios. APRA is coordinating with other regulators, with input from the Commonwealth Scientific and Industrial Research Organisation and Bureau of Meteorology. The exercise is expected to be completed during 2021, with aggregated results published in 2022. It may then be extended to other banks, insurers and superannuation funds although there is no timeline yet. Broadening future exercises will help institutions and regulators alike to better understand exposures and make a swifter, smoother transition. In future stress testing, a dynamic approach could be implemented to allow for opportunities, such as expected valuation increases stemming from renewable energy (OECD, 2021b).

Looking further ahead, banks and regulators should prepare for the possibility that international standards require climate-related risks to be incorporated in the measurement of capital adequacy. There is growing evidence that climate-related risks affect credit risk, which would therefore affect capital requirements (BCBS, 2021). The Basel Committee on Banking Supervision has highlighted that climate risks can also affect market risk, liquidity risk and operational risk and called for more research (BCBS, 2021). Scenario analysis is one way of generating data to help assess these risks. Indeed, the European Central Bank has indicated that climate scenario analysis and stress tests should explicitly feed into capital adequacy calculations and other central banks may follow (OECD, 2021b).

\section{Funding the green transition}

To address market failures related to the energy transition directly, the Clean Energy Finance Corporation (Australia's green bank) and the Australian Renewable Energy Agency (a fund that makes grants for earlystage projects) support finance for projects related to energy efficiency and new technologies related to reduced emissions and renewables. The Clean Energy Finance Corporation is especially noteworthy as it is one of only a handful of national green banks in OECD countries (OECD, 2019b). A recent statutory review found that it had leveraged AUD1.80 to AUD2.90 for every dollar invested since inception (Deloitte, 2018). The review also highlighted that the Corporation had helped develop debt and equity markets for clean energy investments, which had been a barrier to private investment. In 2020 a new investment mandate came into effect prescribing that the Corporation also invest in advancing hydrogen.

The government can also facilitate the financial flows needed for an orderly transition by strengthening the taxonomies and labelling of funds and financial instruments, and supporting the development of transitionrelated instruments and tools, such as benchmarks that can be used to create indices (OECD, 2021b). The OECD's 2020 Business and Finance Outlook shows that ESG-scored investment is growing rapidly but that inconsistent ratings methodologies undermine this effort (OECD, 2020f). In Australia "responsible investment" funds that primarily integrate ESG factors had AUD1 trillion (EUR 620 billion) in funds under management at June 2019, up 47\% from 2018 (Boele and Bayes, 2020). In 2020 the S\&P/ASX200 ESG Index was created. There are now several exchange-traded funds with ESG or environmental themes. Various definitions and measurement of terms such as green and sustainable and apparent inconsistencies in ESG ratings highlighted in OECD (2020g) create uncertainty and risks for investors. 
Likewise, the Australian market for green bonds (as well as other sustainability-linked instruments) is growing quickly with some issues oversubscribed (OECD, 2019b; Figure 24). But again there are multiple sources of validation and certification that hinder such instruments as a tool to improve efficiency of financing (OECD, 2020f).

\section{Figure 24. Green bonds have grown rapidly}

A. Total issuance $2018-20$

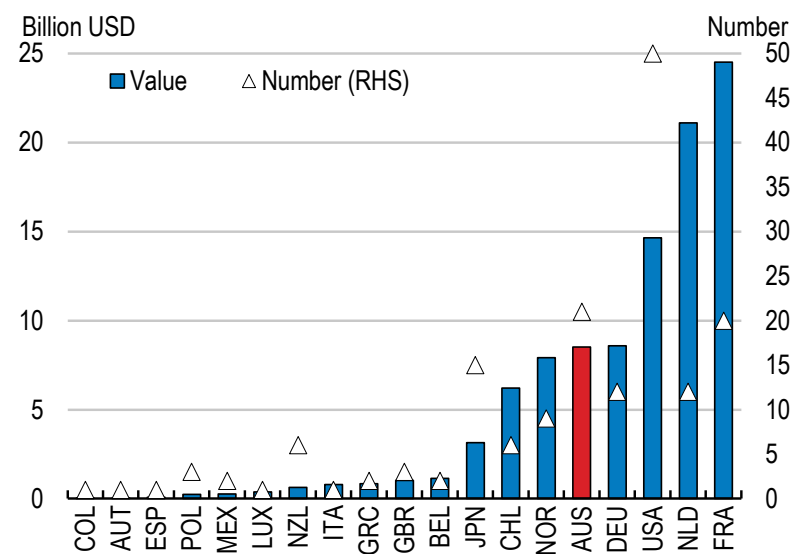

\section{B. Australian issuance}

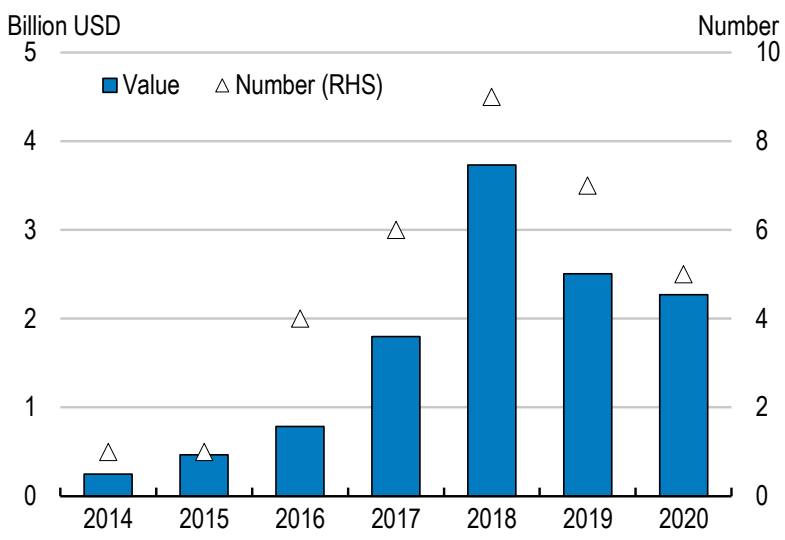

Note: Seven confidential transactions are not shown.

Source: Climate Bonds Initiative.

Clearer definitions and labelling would enhance incentives and avoid greenwashing. Australian authorities should continue to work closely with international bodies to develop consistent global taxonomies for sustainable finance, including through participation in the G20 Sustainable Finance Working Group. In line with the Australian Sustainable Finance Roadmap (ASFI, 2020), Australia should form an expert group, with industry participants, to develop a plan to implement a taxonomy of sustainable finance in Australia. Japan, the European Union, United Kingdom and Canada all used expert groups in a similar context. The taxonomy should assess whether a companies' activities are "green" or "brown" as well as the extent to which it is undertaking verifiable actions to transition to low-carbon activities (OECD, 2021b). The expert group could also develop climate transition benchmarks that can be used to create reliable equity and debt indices, as in the European Union (Box 6).

More immediately, managed funds should also be required to regularly disclose their portfolios to assist investors and allow evaluation of claims related to a fund's investment strategy. Disclosure currently lags other developed financial markets (Morningstar, 2020). The requirement for superannuation funds to disclose their holdings semi-annually has been postponed repeatedly, with implementation now deferred to 31 December 2021. It should be implemented and broadened to other types of funds. APRA is currently updating its prudential standard and should take this opportunity to establish minimum expectations on ESG risk management and, for banks, due diligence in lending transactions in line with the OECD and UNEP standards. 


\section{Box 6. The EU climate benchmarks}

In 2019 the European Commission implemented two climate benchmarks based on the EU Technical Expert Group on Sustainable Finance:

(i) an "EU Climate Transition Benchmark": with underlying assets that ensure the benchmark is on a decarbonisation trajectory; and

(ii) an "EU Paris-Aligned Benchmark": with underlying assets ensuring that the portfolio's greenhouse gas emissions are aligned with the Paris Climate Agreement goals.

In both cases benchmarks using these labels must be constructed in accordance with minimum standards. For the Transition Benchmark the minimum standards are to:

- Reduce the greenhouse gas emissions intensity of the index by $7 \%$ annually, using scope 1,2 , and 3 emissions for each company from inception. This aligns the index with carbon neutrality by 2050 .

- Overweight companies with publicly disclosed science-based targets that meet specified thresholds.

- Maintain or improve the green-to-brown revenue share within the index over time.

- The Paris-Aligned Benchmark has stronger minimum standards for decarbonisation and the green-to-brown revenue shares over time.

Source: Adapted from OECD (2021), Financial Markets and Climate Transition, forthcoming; EU Technical Expert Group on Sustainable Finance (2019), TEG Final Report on Climate Benchmarks and Benchmarks' ESG Disclosures.

\section{Maintaining well-functioning insurance markets amid more frequent climate-related natural disasters}

The increasing prevalence of severe climate-related natural disasters will require adaptation to resulting loss and damages (Wolfrom and Yokoi-Arai, 2016). Australia's recent Royal Commission into Natural Disaster Arrangements highlighted that more frequent disaster events may reduce insurability or affordability of insurance coverage, thereby exacerbating the insurance gap that hampers the ability of economies to recover from natural disasters (Royal Commission into Natural Disaster Arrangements, 2020). Climate change is also complicating risk assessment for the insurance and financial services sector, as past experience is becoming less of a guide to future risks.

There are various public policy options for addressing constraints to the availability and affordability of insurance coverage for disaster risks. Effective public investment in resilience in disaster-prone areas will be important. In Australia, the government announced in the 2021-22 Budget investment of AUD209.7 million to establish the Australian Climate Service. This institution will bring together information and expertise on how to anticipate, manage and adapt to natural disasters. In addition, a National Recovery and Resilience Agency has been set up to co-ordinate resilience to, and recovery from, hazards and disasters, with a strong presence in local communities. The government has also announced AUD615.5 million for the Preparing Australia Program to provide grants for projects that support public and private disaster risk reduction and resilience.

Public support for coverage of disaster risks by private insurance markets may also be increasingly needed. To improve the accessibility and affordability of insurance in cyclone-prone areas, the Australian government also announced in the 2021-22 Budget that it would establish a reinsurance (i.e. insurance for insurers) pool covering the risk of property damage caused by cyclones and cyclone-related flood damage. By decreasing the cost of reinsurance, it is intended that the establishment of the pool will lower insurance premiums. 


\section{Strengthening households' resilience and mitigating inequality}

Despite rising household indebtedness, measures of severe financial stress had been declining in the leadup to the pandemic. Nevertheless, some types of households, including households qualifying for unemployment benefits and disability payments, had experienced greater rates of stress (Phillips and Narayanan, 2021). During 2020, pressures on household finances were alleviated by the abovementioned government income support and banks' loan repayment deferrals, as well as rent freezes. Consequently, financial stress did not rise as much as feared during 2020 and households accumulated savings buffers (RBA, 2021). Liquidity buffers for mortgage holders and renters began declining in late 2020 but remained elevated into 2021 (RBA 2021). Personal insolvencies have not yet increased, nor have debt write-offs, but they are expected to do so as households deplete their buffers following the withdrawal of some policy support for firms and individuals and the reimposition of COVID-19 restrictions. The pandemic has also accelerated the digital transformation of financial services, generating benefits and risks for consumers (OECD, 2020g, 2018d). Consumer protections combined with access to counselling services and targeted financial education can contribute to ensuring that the recovery does not worsen financial inequality.

\section{Ensuring consumer credit protection is appropriate}

Effective financial consumer protection laws help offset market failures such as information asymmetries and behavioural biases that can lead to over-indebtedness and other financial problems. These failures form the backdrop to the OECD Recommendation on Consumer Protection in the Field of Consumer Credit. Responsible business conduct of financial services providers and intermediaries grew in prominence globally after the 2008/09 financial crisis. In Australia various reviews into inappropriate lending and misconduct culminated in the Royal Commission into Misconduct in the Banking, Superannuation and Financial Services Industry, which released its findings in 2019 (Table 2; Annex A). The Royal Commission's findings were wide-ranging, extending beyond banking to financial advice, insurance and superannuation. In relation to credit, it highlighted a range of breaches of responsible lending principles, poorly designed incentives and conflicts of interest that led to consumers' overindebtedness and poor treatment by lenders (Annex Table A.1).

The government released its response to the Royal Commission in February 2019, committing to act on all 76 recommendations. The authorities consider that of the 54 recommendations directed to government, 39 have so far been legislated or otherwise completed, though some have been implemented in a modified form. Legislation to implement a further recommendation is before the Parliament and another nine have undergone public consultation, including the release of draft legislation. The government allocated extra funding to regulators and passed legislation to strengthen their powers and increase the penalties available to them. While the government has made significant progress in implementing the reforms, several recommendations have not yet been addressed. These include removing an exemption from the National Consumer Credit Protection Act for retailers selling loans to consumers at the point of sale, which the government initially agreed to (Annex Table A.1). Changes to mortgage brokers' commissions and regulation are less far-reaching than recommended. A national scheme for mediating farm debt is also

outstanding, with the Commonwealth Government relying on the States to change legislation. The authorities should finalise the implementation of the outstanding reforms.

The government is currently undertaking reforms to the Consumer Credit Act. These involve replacing responsible lending obligations for most forms of consumer credit that are in the Consumer Credit Act with regulations overseen by APRA and ASIC. In doing so, extensive guidance accompanying the application of the obligations in the Act will be eliminated. These changes aim to support the flow of credit by ensuring that strong consumer protections do not come with an undue compliance burden for borrowers and lenders. Responsible lending obligations in the Act would continue to apply to consumer leases and small amount credit contracts ("payday lending"). If passed, APRA will continue to oversee bank lending standards, which will include an additional requirement that lenders should ensure borrowers can repay the loan without substantial hardship. ASIC will enforce a similar standard for non-bank lenders as it relates to the credit 
assessment and approval process. Consumer groups and academics have expressed a number of concerns, including that APRA may not have sufficient expertise for consumer protection responsibilities and that too much responsibility shifts to borrowers (Bant et al., 2021; Consumer Action Law Centre, 2021; Davis, 2020). ASIC believes that the current obligations provide credit providers and intermediaries with flexibility in how they meet the requirements (ASIC, 2021a). If passed, it will be critical that the impacts of the changes are reviewed once they have been in operation for some time to ensure that they increase regulatory certainty and reduce compliance burdens while maintaining strong consumer protections, particularly in the current low-interest-rate environment which incentivises lending.

On the other hand, new "design and distribution obligations" accompanied by product intervention powers will strengthen consumer credit protections (as well as for other financial products, including superannuation and insurance). Issuers will be required to take into account their target consumers' needs, such as their stage of life and financial situation, when designing, marketing and distributing products. The changes will come into effect on 5 October 2021. They mark an important shift from the reliance on disclosure in combination with financial advice and financial literacy, recognising that more information does not necessarily lead to informed consumers or better outcomes (ASIC/AFM, 2019). The obligations follow the United Kingdom, Netherlands and European Union. These do not replace responsible lending because they apply at the product level but they do strengthen consumer protections. Because this is a principles-based approach and allows for proportionality, its enforcement will determine the impacts on consumer outcomes, compliance burdens and industry structure.

Small-amount credit contracts, a form of payday lending, and consumer leases will be more closely regulated recognising that they are high-cost forms of credit that tend to be used by vulnerable individuals. While payday lending can in principle increase financial inclusion for some consumers, it can add to risks of over-indebtedness and financial exclusion (OECD, 2019c). Late or missed payments damage the borrower's credit record. Debt can also spiral: survey data of borrowers' experiences suggest that $15 \%$ of borrowers will fall into a debt spiral (SDTA, 2019). The effective interest rate of a 12-month consumer lease could be $80 \%$ to over $200 \%$ depending on the type of lease provider and $112 \%$ on loans from a payday lender for a 12-month loan (ASIC, 2018b). The high cost of consumer leases reflects ineffective price competition rather than the risk of default (ibid.). Moreover, the gap with alternative forms of credit suggests that consumers are unaware of cheaper credit or unable to secure it. Digitalisation has increased accessibility of payday loans, with the share originated online rising to $86 \%$ in 2019 from $35 \%$ in 2014 (SDTA, 2019).

The combination of responsible lending obligations and design and distribution obligations is expected to strengthen consumer protections for consumer leases and small-amount credit contracts. The proposed amendments to the Consumer Credit Act would also prohibit some forms of unsolicited sales, limit the total cost of consumer leases (payday loans are subject to a cap), cap the share of income an individual can pay for these products at $20 \%$ for each product (with a $10 \%$ cap for customers receiving half of their income from social security benefits), and introduce additional disclosure requirements to assist customers in understanding the contract. While welcome, the new protections will be less stringent than what was recommended by an independent review of these products in 2016, given concerns over the viability of smaller lenders if fully adopted. For instance, that review recommended capping payments at $10 \%$ of income in all instances. The overall cap would include additional fees and charges, adding to the effective interest rate and incentivising up-selling (SDTA, 2021). Unlike most other OECD countries, there is no cooling-off period allowing a consumer to change their mind without penalty.

The proposed consumer credit reforms will also remove responsible lending obligations for credit cards from the Act and replace them with the strengthened lending standard overseen by APRA. Credit cards have historically been linked to financial distress for some households, with high interest rates when balances are not repaid (17\% in mid 2021) (ASIC, 2018c). Assuming that the proposed reforms are passed, the impact of the changes across products should be closely monitored, especially regarding high-cost credit, and additional protections introduced if it is evident that consumer protections are insufficiently strong. 
Raising access to, and awareness of, earlier interventions and alternatives to payday lending could improve outcomes for financially stressed individuals. Awareness of more affordable credit and free financial counselling services is too low. An advertising campaign launched in April 2021 by the National Debt Helpline was timely, given the end of several temporary forms of support, and a step in the right direction. Before the pandemic, just three in five people who sought assistance received financial counselling (Sylvan, 2019). Adequately resourcing these services during the recovery should be a priority. Affordable credit programmes, such as the No Interest Loans Schemes, should also be expanded and funding made more predictable. Together this could prevent vulnerable consumers, who are less likely to have the capability to make good financial decisions, turning to more expensive inefficient options. The 2019 review of financial counselling services also highlighted the need for consistent data collection and more analysis and co-ordination (Sylvan, 2019). Under newly enacted consumer credit reforms, debt management firms will be regulated more closely to address concerns of ASIC and consumer representatives, including that high fees for services such as debt negotiation can leave consumers worse off (ASIC, 2018b). ASIC should actively enforce these regulations. Narrowing gaps in financial literacy and capability, discussed below, would better equip those navigating complex decisions.

The Royal Commission also highlighted cases of inappropriate and conflicted financial advice associated with lending to self-managed superannuation funds, which are allowed to borrow for investment purposes using limited recourse borrowing arrangements. Almost $10 \%$ of self-managed superannuation funds do so, representing around $5 \%$ of funds' assets on average (CFR/ATO, 2019). Housing has been the most common asset acquired ( $61 \%$ of funds and $49 \%$ of assets by value), followed by non-residential real estate ( $46 \%$ by value), whereas equity investments were small (ibid). Although it is not a systemic issue, it poses a growing risk to individuals' retirement savings as loans have limited recourse but often have a personal guarantee. Funds that hold these assets typically have low balances (AUD200 000-AUD500 000). And for that group, around $85 \%$ of assets are held under these borrowing arrangements, raising concerns about asset concentration. While major banks withdrew from this market, less-regulated non-bank lenders have become more active (AFR, 2021). These risks could be mitigated by preventing funds from borrowing as recommended in Australia's Financial System Inquiry (Murray et al., 2014).

The digitalisation of financial services and accompanying innovation also entails regulatory challenges. For instance, there is a trade-off between maintaining a level-playing field and preventing regulatory arbitrage while providing a hospitable environment for innovation and new entrants. Most prominently, these challenges have been highlighted by rapid growth and development in "buy now, pay later" services. These are generally not treated as consumer credit in Australia (due to factors such as the fee structure or term of the credit) but are subject to broader consumer protection. However, amounts can be comparable to credit cards: for example, buy-now-pay later is available for healthcare costs with a limit of AUD10 000 (ABC, 2021). Research by ASIC showed rapid growth in products, providers and take-up (ASIC, 2020a). In June 2020, transactions were equivalent to $4.2 \%$ of personal credit and charge card transactions, up from 2.5\% a year earlier. One-fifth of customers surveyed by ASIC in 2019 had missed payments during the previous 12 months. These were disproportionately aged 18-24 years relative to the distribution of transactions. Of further concern is that one-fifth of customers cut back on or went without essentials to make payments on time and $15 \%$ took out an additional loan to do so.

In response to pressure for regulation, the buy-now-pay-later industry has published a voluntary code of practice that includes additional checks (though not always with credit bureaus) and provides consumers access to an external dispute resolution mechanism via the financial services ombudsman. The industry is subject to ASIC's product intervention powers and, from October 2021, to the new design and distribution obligations. ASIC has signalled that it will watch closely how issuers and distributors adhere to their design and distribution obligations and will intervene if a product is significantly harming consumers (or likely to). The new and digitalised nature of these firms presents an opportunity to find regtech solutions to enhance monitoring and ease reporting burdens. Nevertheless, regulatory differences with other credit products will remain. For instance, providers of credit up to AUD15 000 do not need to perform a credit check, which also means that other lenders may not be aware of a borrower's repayment difficulties. By comparison, the United Kingdom is bringing buy now, pay later under the Financial Conduct Authority's responsibility in a proportional way, partly to ensure consistent outcomes across users of substitutable credit products. Given the rapid growth in the industry, regulatory differences with other credit providers should be closed, 
for instance by regulating such products as consumer credit under the National Consumer Credit Protection Act 2009. This would strengthen consumer protections and ensure a level playing field with other more regulated forms of credit.

\section{Narrowing gaps in financial literacy and inclusion}

Even with stronger consumer protections, financial literacy will be an important determinant of financial inclusion and well-being. The empirical research shows that financial literacy affects economic decisionmaking, including savings behaviour and debt management (Lusardi and Mitchell, 2014; Lusardi and Tufano, 2015). Overall, measures of financial literacy and inclusion are comparatively high in Australia (Figure 25). Nevertheless, a large share of survey respondents $-36 \%$ - did not even demonstrate a basic level of financial knowledge. Data from the HILDA Survey show that financial literacy levels are uneven: controlling for other characteristics, being a woman, young, born in a non-English-speaking country, Indigenous and not completing high school are associated with lower levels of knowledge (Figure 26). The data also show that higher levels of financial knowledge are associated with better financial behaviours such as credit card repayment, seeking to understand financial contracts, setting long-term financial goals and saving. With the digitalisation of finance, digital access and knowledge will be increasingly important. Again, overall access is high but digital inclusion, including measures of ability, is lower for less educated, older, disabled and Indigenous Australians as well as those outside the labour force (Barraket et al., 2020).

Figure 25. Overall levels of financial knowledge and inclusion compare well

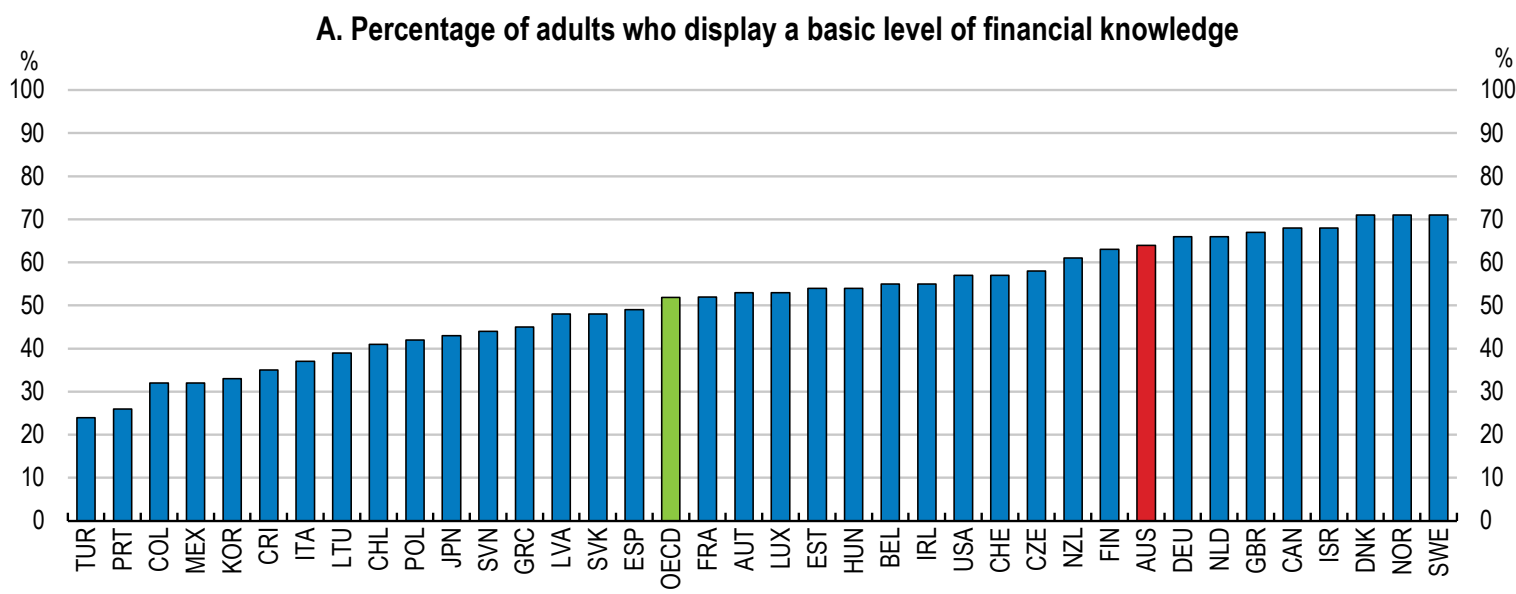

B. Measures of financial inclusion

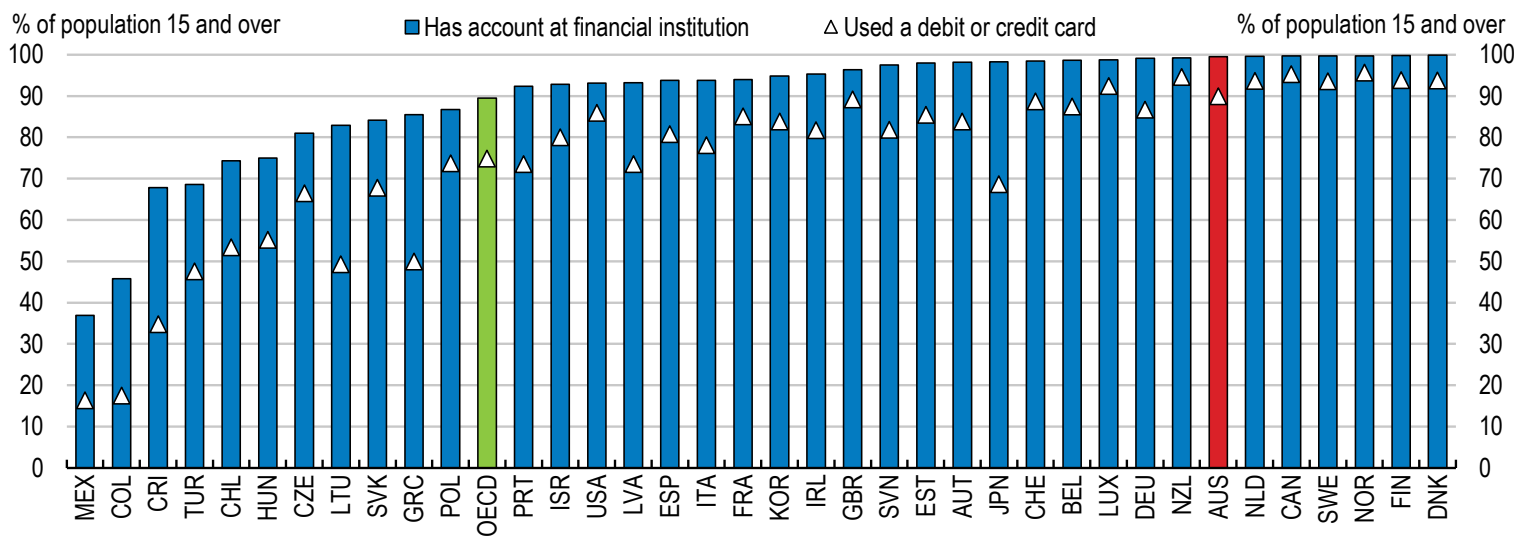

Note: The S\&P Global Financial Literacy Survey measures financial knowledge based on four concepts: risk diversification, inflation, numeracy, and interest compounding. A person is defined as financially literate if they correctly answer three out of four topics.

Source: Klapper, L. et al. (2019), Financial Literacy Around the World: Insights from the Standard \& Poor's Ratings Services Global Financial Literacy Survey, Global Financial Literacy Excellence Centre; World Bank, G20 Financial Inclusion Indicators Database. 


\section{Figure 26. Financial knowledge is strongly related to demographic characteristics}

\section{Estimated regression coefficient on variable shown}

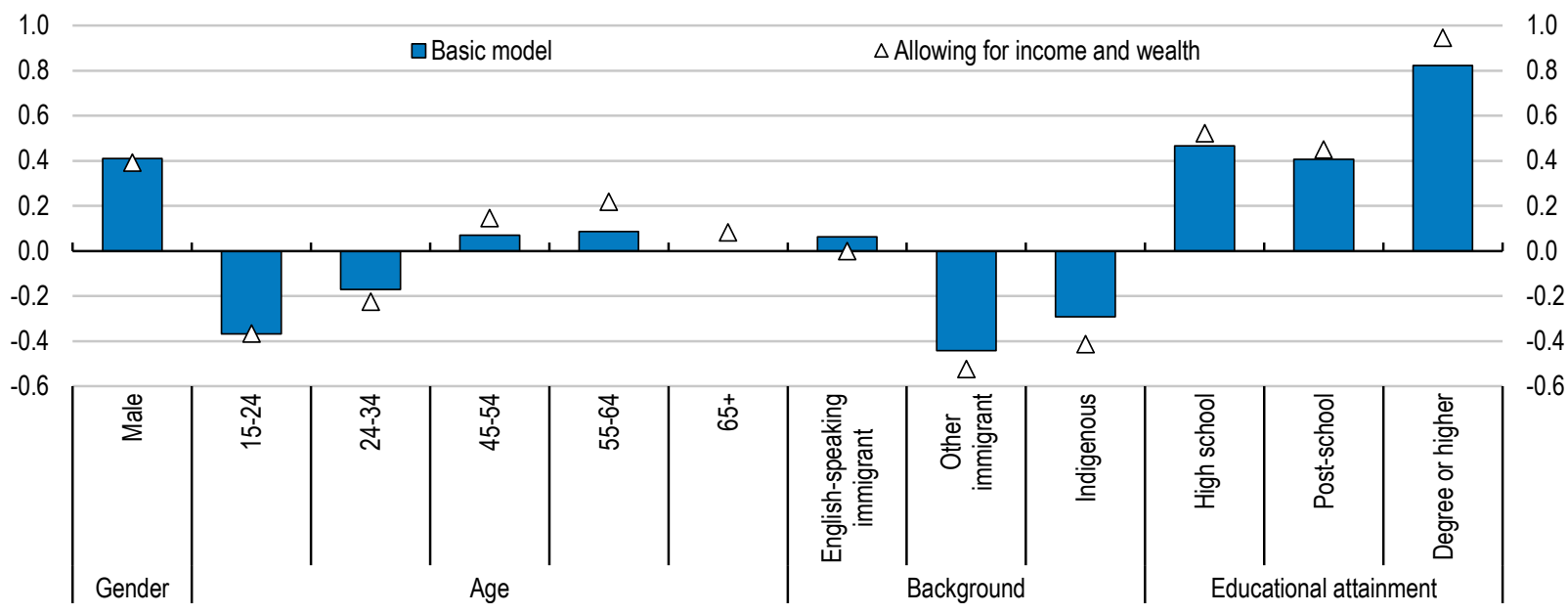

Note: Coefficients are from two regression models. The dependent variable is the number of correct responses to five financial knowledge questions. The basic model includes gender, age, place of birth and Indigenous status, relationship in household, educational attainment, region, labour force status and a constant. The second model is identical but includes income and wealth. In the categories shown, the reference groups are: female, 35-44 year-olds, Australian-born non-Indigenous, educated to less than high school.

Source: Wilkins, R. "Financial literacy and attitudes to finances", Chapter 9 in R. Wilkins and I. Lass (2018), The Household, Income and Labour Dynamics in Australia Survey: Selected Findings from Waves 1 to 16, Melbourne Institute: Applied Economic \& Social Research, Melbourne.

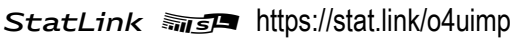

Australia has had a national financial literacy strategy since 2011 with financial education in schools at its core. It has been a leader in recognising the important influence of personal circumstances on financial decision-making (OECD, 2015b). In the third strategy in 2018, literacy was broadened to "capability": "being able to talk about money, to make informed decisions about money and to feel financially secure". However, unlike the previous strategy, the current published strategy is a high-level document and is not supported by measurable targets or details of implementation, monitoring and evaluation. Since late 2020, the strategy has been led by Treasury, which is in the process of revising it and plans to build on the monitoring and evaluation framework that ASIC began.

Delivery of financial capability programmes is decentralised. The Australian financial capability community comprises government departments and agencies, educational institutions and organisations, not-forprofits and firms that undertake initiatives aligned with the strategy. ASIC is responsible for three key elements: the Moneysmart website, which provides calculators and other resources; financial education support materials for schools; and provision of consumer education via the Indigenous Outreach Program. The Moneysmart website is an example of best practice, incorporating behavioural insights and is a hub of easily accessible information, particularly during the pandemic. Almost half of all Australians accessed the website in 2019-20 (ASIC, 2021b). ASIC also commissioned the Financial Attitudes and Behaviour Tracker annually from 2014-2018. The Tracker was used to inform programmes and initiatives in conjunction with other inputs such as the Financial Wellbeing Survey of Adults in Australia commissioned every three years by a commercial bank. The activities of other members of the financial capability community vary widely in scale and content.

Financial education improves financial knowledge and behaviours (Kaiser et al., 2020). Australia stands out for embedding financial education into the school curriculum until year 10 (around age 16) (OECD, 2019d). This approach is recognised as an efficient way of reaching a generation (OECD, 2020h). Students in Australia have comparatively good financial literacy scores on average (Figure 27). However, 16\% of 
students lacked basic proficiency and the gap between advantaged and disadvantaged students is comparatively large (OECD, 2020i). In addition to formal learning, some financial education is delivered informally. However, a recent review of school banking programmes offered by 10 banks at almost 4000 schools found these programmes to be marketing exercises without a discernible benefit (ASIC, 2020b). Three jurisdictions have proposed banning the programmes. In practice, financial education varies across schools (ASIC, 2020b) and students at more socially advantaged schools had greater exposure to financial education concepts (OECD, 2020i). Narrowing gaps is especially important given that young people are being exposed to financial services at a younger age due to digitalisation. Indeed in $201855 \%$ of Australian 15 year-olds had mobile phone access to a financial account, which was one of the highest rates in the OECD (OECD, 2020i).

Recognising these challenges, in 2020 ASIC established an expert group on young people and money to inform its work. Governments should allocate more resources for financial education at less advantaged schools, drawing on results from the recent ASIC study and PISA tests. Teachers should be encouraged to undertake the free online accredited training in teaching financial education. A code of conduct could be created to govern private sector involvement in financial education, as in Spain (OECD, 2020h). Beyond schools, additional focus could be given to interventions at teachable moments, such as receiving a first paycheck. In the United States organisers of youth employment programmes were encouraged to partner with financial institutions to provide financial education and access to an appropriate saving account, which led to long-lasting effects on financial knowledge and behaviours (OECD, 2020h). The Moneysmart website could be extended to include not only teaching resources but financial education for youth, following the example of Ireland's Money Matter's website, or the financial health check on Singapore's MoneySense website (OECD, 2020h). Other countries are also using digital tools to develop more tailored and engaging resources (OECD, 2021c). Policy-makers should continue to develop and evaluate digital financial education tools and resources, including by building on existing strengths such as the Moneysmart website.

\section{Figure 27. Financial literacy is a little above the OECD average with wide dispersion}

PISA score for financial literacy

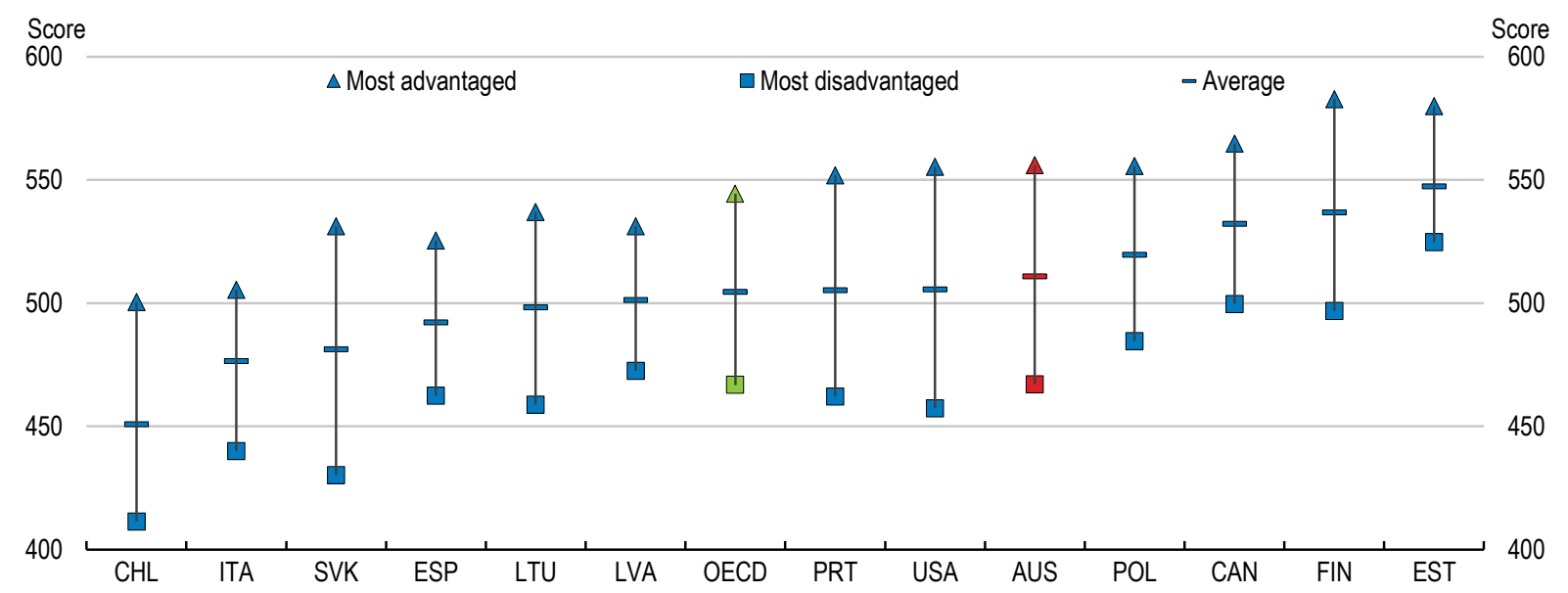

Note: Most advantaged (disadvantaged) is the average of the upper (lower) quartile of the distribution by socio-economic status. Source: OECD (2020), PISA 2018 Results (Volume IV). 
The gaps in traditional measures of financial literacy and inclusion are particularly large and persistent for Indigenous Australians (Figure 28, Panels A and B). This is a challenge common to several OECD countries, notably Canada, Mexico, New Zealand and the United States (OECD, 2020b). Survey data on financial literacy showed minimal improvement over 2003 to 2014 despite a plethora of programmes (Wagland and Taylor, 2015). Around half of all Indigenous Australians face high or severe levels of financial stress compared to $10 \%$ of the general population (Figure 28, Panel C). They are less likely to have savings to access in an emergency and more likely to use fringe credit (payday lenders or similar) (Figure 28, Panel D; Weier et al., 2019). The Royal Commission listed ways of easily reducing financial exclusion that were not being used, as well as egregious cases of mis-selling and misconduct (Hayne, 2019). There is growing recognition that in addition to socio-economic factors and remoteness, cultural factors drive outcomes and policy-making must start with these (Russell et al, 2020; Wagland and Taylor, 2015). Other factors, including receiving mining royalties, also complicate financial management in some communities (Russell et al., 2020).

Figure 28. Financial inclusion, knowledge and resilience are lower for Indigenous Australians
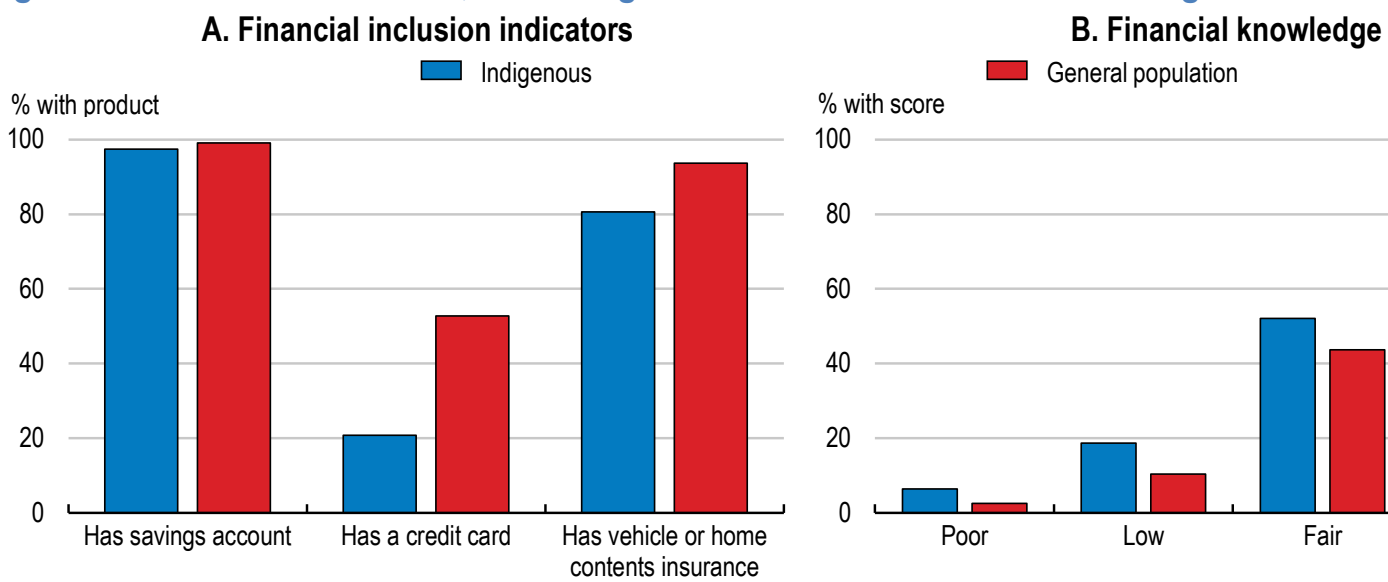

\section{Financial vulnerability}
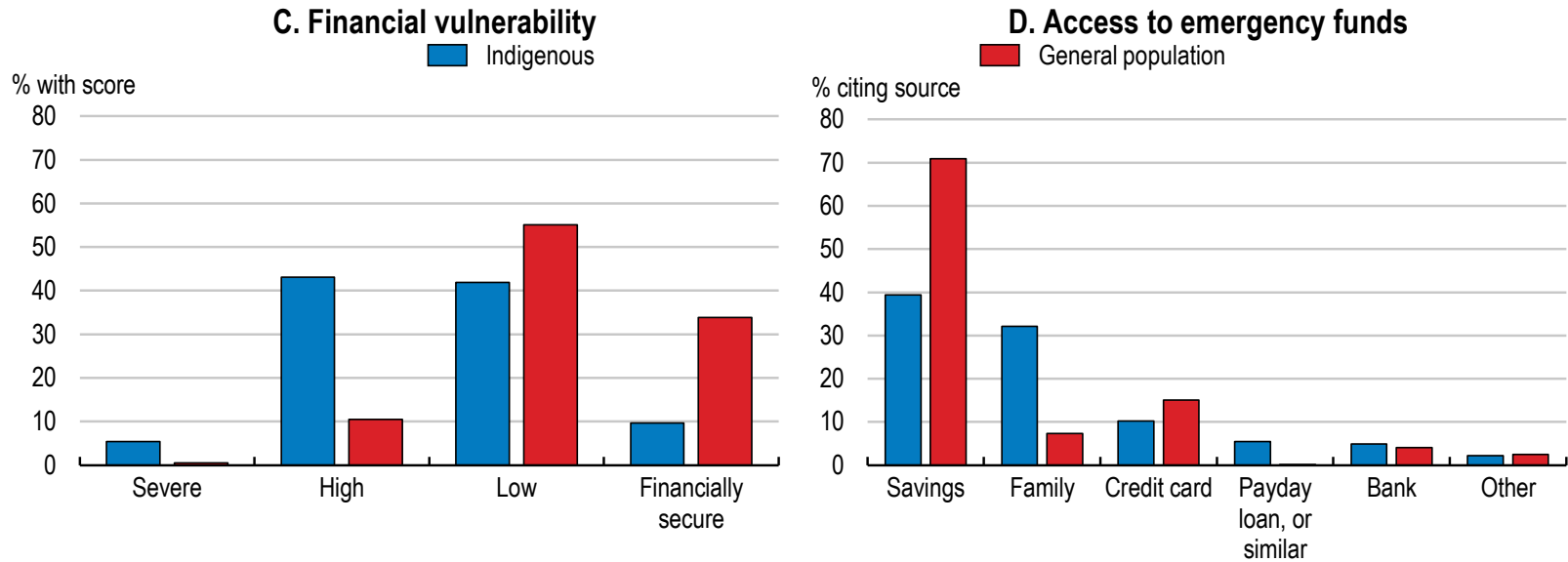

Note: Indicators in Panel A are from the 2018 wave of the Household, Income and Labour Dynamics in Australia (HILDA) survey. Savings account is alone or joint. Insurance refers to the household. Panel $B$ is based on five questions from the 2016 wave of the HILDA survey with the following scoring: "high" for five correct answers; "fair" for three or four correct answers; "low" for one or two correct answers; and "poor" for no correct answers. The HILDA Survey is conducted by the Australian Government Department of Social Services (DSS). The findings and views reported in this Working Paper, however, are those of the authors and should not be attributed to the Australian Government, DSS, or any of DSS' contractors or partners. The composite indicator in Panel C comprises indicators of economic resources, access to financial services, financial knowledge and behaviour and social capital; see Weier et al. (2019) for methodological details

Source: M. Weier et al. (2019), Money Stories: Financial Resilience among Aboriginal and Torres Strait Islander Australians 2019; Household Income and Labour Dynamics in Australia (HILDA) database and OECD calculations. 
There has been a shift towards designing programs to fit into Indigenous culture, sometimes led by Indigenous organisations. For instance, ASIC has created a resource delivered via its Moneysmart website that tackles issues faced by Indigenous Australians, such as managing store credit and requests for money from family and friends. It also includes teaching resources. ASIC is also creating a financial capability roadmap in consultation with Indigenous stakeholders around the country as part of its Indigenous Outreach Programme. This should lead to more locally-driven and Indigenous-led programmes. A potential source of funding for such programmes is Ecstra, a not-for-profit organisation that was partly financed through the large penalties charged to banks for past misconduct. Another possibility would be to equip the National Indigenous Australians Agency (a government agency) with resources to oversee such programmes with ASIC. The financial sector, particularly the major banks, is also active, with programmes to build financial inclusion (e.g. matched savings programmes, microfinance), financial literacy and cultural awareness within their own institutions. But more research is needed to understand factors such as barriers to Indigenous financial literacy and attitudes to money so that programmes can better fit Indigenous Australians' needs (Russell et al., 2020; Wagland and Taylor, 2015). In 2021 the RBA formed a Central Bank Network for Indigenous Inclusion with indigenous partners, the Reserve Bank of New Zealand and the Bank of Canada. Its activities will include research, sharing best practices and supporting financial education.

Expanding materials produced in Indigenous languages could help increase usage and understanding. New Zealand's version of the Moneysmart website is produced in Māori. Although there are many more indigenous languages in Australia than New Zealand, priority could be given to those more likely to be a first language or the 13 that are spoken by children. Improving financial inclusion could also help improve access to finance for Indigenous entrepreneurs. In the United States and Canada the government supported the development of networks of financial institutions owned and operated by First Nations peoples (OECD, 2019e). These have been operating for around three decades and have helped develop businesses and financial literacy within their communities. Indigenous Business Australia offers business and home loans on behalf of the government whereas the Canadian and US approaches are grassrootsbased. The model could be adapted to Australia, where population density is lower, by pooling risk and resources across multiple local institutions or partnering with a bank, for example. Continuing to better understand the difficulties Indigenous businesses face accessing finance should help improve policymaking and, accordingly, outcomes.

More generally, the transfer of responsibility for national financial capability policy to the Treasury is an opportunity to more actively co-ordinate the myriad of programmes across the country. Duplication in activities should be minimised and programmes that are succeeding should receive support to be extended elsewhere. In the case of localised programmes, such as those for Indigenous Australians, greater support should be provided for community-driven initiatives with knowledge-sharing of successful initiatives. In keeping with the OECD Recommendation on Financial Literacy the Financial Capability Strategy should be accompanied by measurable goals, an implementation plan and plan to monitor and evaluate the strategy against its targets. In particular, it should set out clear and ambitious objectives for groups that have been identified as facing greater challenges, namely women, youth, the elderly, people with disabilities, Indigenous Australians and people from culturally and linguistically diverse backgrounds.

The strategy should also recognise the challenges and opportunities of the digital transformation, in keeping with OECD guidance (OECD, 2020j, 2018e). Treasury should work closely with ASIC to ensure that institutional knowledge is maintained and there are mechanisms for sharing insights gleaned by each. A hub or conference could bring together available research and key actors working on key challenges such as better reaching vulnerable groups and trends such as taking advantage of digitalisation. A coordinated awareness campaign like a financial capability month, as in Canada, Italy and the United States, would allow Australia to harness the strengths of a decentralised approach and increase the impact of existing initiatives. 


\section{Box 7. Measuring financial literacy in Australia}

The OECD defines financial literacy as "a combination of financial awareness, knowledge, skills, attitudes and behaviours necessary to make sound financial decisions and ultimately achieve individual financial well-being" (OECD, 2020).

Australia's main longitudinal survey, the Household Income and Labour Dynamics in Australia (HILDA) Survey, included questions to measure financial literacy in 2016. Following Lusardi and Mitchell (2014) it asked five questions relating to:

- Numeracy: Calculating the worth of AUD100 in a savings account earning $2 \%$ after one year.

- Inflation: Whether those savings would be worth more, the same or less if interest was $1 \%$ and inflation was $2 \%$ per year.

- Diversification: Whether "buying shares in a single company usually provides a safer return than buying shares in a number of different companies".

- Risk-return: Whether "an investment with a high return is likely to be high risk".

- Money illusion: Change in purchasing power (can buy more, the same or less) if in two years' time both income and prices have doubled.

An aggregate indicator of financial literacy is calculated as the sum of the correct answers. "Don't know" and "refused to answer" are treated as incorrect unless the respondent refused to answer all five questions, which was then treated as missing.

Source: Wilkins, R. "Financial literacy and attitudes to finances", Chapter 9 in R. Wilkins and I. Lass (2018), The Household, Income and Labour Dynamics in Australia Survey: Selected Findings from Waves 1 to 16, Melbourne Institute: Applied Economic \& Social Research, Melbourne. OECD (2020), Recommendation on Financial Literacy, www.oecd.org/finance/OECD-Recommendation-on-FinancialLiteracy.htm; Lusardi A. and O. Mitchell (2014), "The Economic Importance of Financial Literacy: Theory and Evidence", Journal of Economic Literature, vol. 52, no. 1, pp. 5-44.

\section{Table 7. Recommendations to ensure the financial sector supports a sustainable and inclusive} recovery

\begin{tabular}{|c|c|}
\hline MAIN FINDINGS & RECOMMENDATIONS (Key recommendations in bold) \\
\hline \multicolumn{2}{|c|}{ Navigating the crisis and early recovery } \\
\hline $\begin{array}{l}\text { The number of insolvencies fell sharply in } 2020 \text { but is expected to } \\
\text { increase. }\end{array}$ & $\begin{array}{l}\text { Increase awareness and support for pre-insolvency actions and offer } \\
\text { firms most affected by restrictions business viability vouchers. }\end{array}$ \\
\hline $\begin{array}{l}\text { Households are amongst the most indebted in the OECD and banks are } \\
\text { highly exposed to housing assets. Risks are moderated by high } \\
\text { household asset holdings, well-capitalised banks and close supervision. }\end{array}$ & $\begin{array}{l}\text { If credit growth picks up and there are other signs of building risks, } \\
\text { implement macroprudential tools. } \\
\text { Complete implementation of a loss-absorbing regime, including bail-in } \\
\text { provisions, in case of financial institution insolvency. }\end{array}$ \\
\hline $\begin{array}{l}\text { The government allowed early access to superannuation at the onset of } \\
\text { the pandemic, supporting adversely-impacted households, including } \\
\text { those in acute financial distress. Online tools were made available to } \\
\text { enable applicants to estimate the effect of withdrawals on retirement } \\
\text { savings, but many applicants either underestimated this or did not } \\
\text { undertake such estimates. }\end{array}$ & $\begin{array}{l}\text { Continue to only allow early withdrawals of superannuation in } \\
\text { exceptional circumstances, such as severe financial hardship. }\end{array}$ \\
\hline \multicolumn{2}{|c|}{ Channelling finance to viable and productive firms } \\
\hline $\begin{array}{l}\text { Data on financing conditions for small firms is lacking, with limited } \\
\text { demand-side surveys and no publicly available supply-side data. }\end{array}$ & $\begin{array}{l}\text { Build on existing surveys to create internationally comparable surveys } \\
\text { of access to finance and credit conditions. }\end{array}$ \\
\hline $\begin{array}{l}\text { Regulatory settings contribute to disincentives for banks to lend to small } \\
\text { firms. Smaller lenders face higher costs than larger banks, hampering } \\
\text { competition. Until } 2023 \text { risk weights for SME lending used by second- } \\
\text { tier banks will be more stringent and less granular than international } \\
\text { standards. }\end{array}$ & $\begin{array}{l}\text { Consider providing temporary capital relief on small business lending by } \\
\text { second-tier banks. } \\
\text { Expand options for second-tier banks to achieve lower risk weights on } \\
\text { small business lending. }\end{array}$ \\
\hline
\end{tabular}


The SME securitised loan market is small. New government funds to invest in securitised SME loans will help to develop the market over time.

The register of security interests over personal property (Personal Property Securities Register) is considered difficult to use and lacks visibility.

Comprehensive credit reporting and the new consumer data right in banking can help improve competition in lending for start-ups and smaller businesses by allowing borrowers to share information with other service providers.

The main equity market facilitates initial public offerings by small firms. However, it has a one-size-fits-all approach to listing and disclosure requirements.
Continue developing the SME securitised loan market, including a centralised data platform with loan-level data and performance history.

Overhaul the Personal Property Securities Register then increase awareness among small businesses and lenders.

Evaluate the case for extending the coverage of comprehensive credit reporting to SMEs and increase awareness.

Publicise the consumer data right so that consumers and firms are wellplaced to benefit from emerging opportunities.

Extend open banking to facilitate switching of providers and other actions ("write access") with appropriate protections.

Incorporate greater proportionality and flexibility in listing and disclosure requirements.

\section{Supporting the green transition}

Disclosure of climate-related risks by listed companies and financial institutions has increased but progress is uneven and there are still large data gaps.

Climate vulnerability assessments are beginning with the five-largest banks in 2021.

ESG investing and use of instruments such as green bonds are growing However, the multitude of definitions may undermine progress.

Create a roadmap for improving the consistency, comparability and quality of reporting of climate-related risks by listed companies and financial institutions.

Expand climate-risk scenario analysis to all banks, insurers and fund managers as soon as possible.

Continue to work closely with international bodies to develop a taxonomy for sustainable finance.

\section{Strengthening households' resilience and mitigating inequality}

A Royal Commission found serious misconduct in the financial sector. The Government has implemented a significant number of the Commission's recommendations, but some reforms remain outstanding. Forms of high-cost credit can perpetuate financial exclusion. Recent reforms before the Parliament will strengthen protections in respect of certain high-cost forms of credit. However, associated changes to reduce regulatory burdens risk gaps in protections arising.

Buy-now-pay-later is growing rapidly. Industry self-regulation creates an uneven playing field with credit providers.

Australia has had a financial literacy strategy since 2011, supported by integration in schooling and decentralised programme delivery. Many Australians still lack sufficient financial knowledge and capability. Indicators of financial inclusion, knowledge and resilience are lower for Indigenous Australians than the general population.

Complete the implementation of the reforms arising from the

Royal Commission into the financial sector.

Ensure that the current reforms to consumer protections are appropriately enforced and evaluated, and further strengthen protections particularly for high cost credit if needed.

Close differences in regulatory treatment of credit-like products and those regulated as consumer credit.

Promote awareness of available financial capability resources through a national campaign.

Provide greater support for Indigenous-led financial capability programmes and knowledge-sharing of successful initiatives. 


\section{References}

$A B C$ (2021), "Buy now, pay later for elective surgery sparks warnings of financial risk", 16 March 2021.

ACCC (2021), "NAB's acquisition of 86400 not opposed", press release, 30 March.

ACCC (2018), Residential Mortgage Price Inquiry, Final report, Commonwealth of Australia, Canberra.

Adalet McGowan, M. and D. Andrews (2018), "Design of insolvency regimes across countries", OECD Economics Department Working Papers, No. 1504, OECD Publishing, Paris.

AFR (Australian Financial Review) (2021), "Non-banks leverage up SMSF property after COVID-19, 15 February.

Allens (2021), PE Horizons 2021, March 2021.

Alston, M., S. Black, B. Jackman and S. Schwartz (2020), "The Term Funding Facility", RBA Bulletin, December.

Andrews, D., M. Adalet McGowan and V. Millot (2017), "Confronting the zombies: policies for productivity revival", OECD Economic Policy Papers, No. 21, OECD Publishing, Paris.

Andrews, D. and C. Criscuolo (2013), "Knowledge-Based Capital, Innovation and Resource Allocation: A Going for Growth Report", OECD Economic Policy Papers, No. 4, OECD Publishing, Paris.

Andrews, D., C. Criscuolo and C. Menon (2014), "Do Resources Flow to Patenting Firms?: CrossCountry Evidence from Firm Level Data", OECD Economics Department Working Papers, No. 1127, OECD Publishing, Paris.

APRA (2021), "Climate Vulnerability Assessment", Information Paper, 3 September 2021.

APRA (2020a), "Stress testing banks during COVID-19", Information Paper, 15 December.

APRA (2020b), "The superannuation Early Release Scheme: insights from APRA's pandemic data collection", APRA Insight, Issue 4.

APRA (2020c), Submission: Senate Select Committee on Financial Technology and Regulatory Technology, 20 January.

APRA (2020d), "Understanding and managing the financial risks of climate change", Letter to all APRAregulated entities, 24 February.

APRA (2019), "Climate change: awareness to action", Information Paper, 20 March.

ASBFEO (2021), "Personal property securities register", Research Paper, February.

ASFI (Australian Sustainable Finance Initiative) (2020), Australian Sustainable Finance Roadmap: a Plan for Aligning Australia's Financial System with a Sustainable, Resilient and Prosperous Future for All Australians, Responsible Investment Association Australasia, Melbourne.

ASIC (2021a), Submission to the Senate Economic Legislation Committee Inquiry into the National Consumer Credit Protection Amendment (Supporting the Economic Recovery) Bill 2020, No. 110.

ASIC (2021b), Financial Capability, https://asic.gov.au/for-consumers/financial-capability/, (accessed 14 May 2021).

ASIC (2020a), Buy Now Pay Later: An Industry Update, Report No. 672.

ASIC (2020b), Review of Banking Programs, Report No. 676.

ASIC (2018a), Climate Risk Disclosure by Australia's Listed Companies, Report No. 593.

ASIC (2018b), Submission to the Senate Economics References Committee Inquiry into credit and financial services targeted at Australians at risk of financial hardship, No. 21.

ASIC (2018c), Credit Card Lending in Australia, Report No. 580.

ASIC (2017), Assessment of National Stock Exchange of Australia Limited's Listing Standards, Report No. 538 . 
ASIC / AFM (2019), Disclosure: Why Shouldn't it be the Default?, Joint report from the Australian Securities and Investments Commission and the Dutch Authority for the Financial Markets, Report No. 632.

ASX (2012), Strengthening Australia's Equity Capital Markets, ASX proposals and consultation.

Australian Government (2020), "Insolvency reforms to support small business", Factsheet.

Bant, E. et al. (2021), Submission to Senate Economics Legislation Committee on the National Consumer Credit Protection Amendment (Supporting Economic Recovery) Bill 2020, No. 91.

Bateman, H. et al. (2020), 20K Now or 50K Later? What's Driving People's Decision to Withdraw Their Super?, CEPAR, Arc Centre of Excellence in Population Ageing Research, August.

Barraket, T.J. et al. (2020), Measuring Australia's Digital Divide: The Australian Digital Inclusion Index 2020, RMIT and Swinburne University of Technology, Melbourne.

Baudino, P., R. Goetschmann, J. Henry, K. Taniguchi and W. Zhu (2018), "Stress-testing banks - a comparative analysis", FSI insights on policy implementation, No. 12, Bank for International Settlements, Basel.

BCBS (Basel Committee on Banking Supervision) (2021), Climate-related risk drivers and their transmission channels, Bank for International Settlements, Basel.

Beck, T., B. Büyükkarabacak, F.K. Rioja and N.T. Valev (2012), "Who gets the credit? And does it matter? Household vs. firm lending across countries", The B.E. Journal of Macroeconomics, Vol. 12/1, pp.1-44.

Birchal (2021), CSF Yearbook 2020, 31 December.

Boele, N. and S. Bayes (2020), Responsible Investment Benchmark Report 2020 Australia, Responsible Investment Association Australasia, Sydney.

Boissinot, J., D. Huber and G. Lame (2016), "Finance and climate: The transition to a low-carbon and climate-resilient economy from a financial sector perspective", OECD Journal: Financial Market Trends, Vol. 2015/1.

Boschmans, K. and L. Pissareva (2018), "Fostering Markets for SME Finance: Matching Business and Investor Needs", OECD SME and Entrepreneurship Papers, No. 6, OECD Publishing, Paris.

Bradley, W. A., G. Duruflé, T. Hellmann, and K.E. Wilson (2019), "Cross-border venture capital investments: what is the role of public policy?", Journal of Risk and Financial Management, Vol. 12/3, pp. 1-22.

Brander, J., Q. Du and T. Hellmann (2015), "The effects of government-sponsored venture capital: international evidence", Review of Finance, Vol. 19/2, pp. 571-618.

Brassell, M. and K. Boschmans (2019), "Fostering the use of intangibles to strengthen SME access to finance", OECD SME and Entrepreneurship Papers, No. 12, OECD Publishing, Paris.

Brown, J.R., G. Martinsson and B.C. Petersen (2012) "Do financing constraints matter for R\&D?", European Economic Review, Vol. 56/8, pp 1512-29.

Byres, W. (2019), Speech to the Customer-Owned Banking Convention, APRA, 11 November.

Calvino, F., C. Criscuolo and C. Menon (2015), "No Country for Young Firms?: Start-up Dynamics and National Policies", OECD Science, Technology and Industry Policy Papers, No. 29, OECD Publishing, Paris.

Carletti, E. and A. Smolenska (2017), "10 years on from the Financial Crisis: Co-operation between Competition Agencies and Regulators in the Financial Sector", Background note to the OECD Working Party No. 2 on Competition and Regulation.

CCAF (Cambridge Centre for Alternative Finance) (2020), The Global Alternative Finance Market Benchmarking Report, April 2020.

CFR / ATO (2019), Council of Financial Regulators and ATO Report to Government: Leverage and Risk 


\section{8}

ECO/WKP(2021)51

in the Superannuation System 2019, February.

Coates, B. (2021), "A big step on the long road to cheaper super", Grattan Institute, Melbourne.

Connolly, E. and J. Bank (2018), "Access to small business finance", RBA Bulletin, September.

Connolly, E. and B. Jackman (2017), "The availability of business finance", RBA Bulletin, December.

Consumer Action Law Centre (2021), "Saving responsible lending: Senate Committee opening statement", press release.

Cournède, B., O. Denk and P. Hoeller (2015), "Finance and Inclusive Growth", OECD Economic Policy Papers, No 14, OECD Publishing, Paris.

Criscuolo C., P.N. Gal and C. Menon (2014), "The Dynamics of Employment Growth: New Evidence from 18 Countries”, OECD Science, Technology and Industry Policy Papers, No. 14, OECD Publishing, Paris.

CSMI (Climate Standards Measurement Initiative) (2020), Scenario Analysis of Climate-related Physical Risk for Buildings and Infrastructure: Financial disclosure Guidelines \& Climate Science Guidance, Summary for executives, Climate-KIC Australia.

Daley, J. and D. Wood (2016), Hot Property: Negative Gearing and Capital Gains Tax Reform, Grattan Institute, Melbourne.

Davis, K. (2020), "None of the justifications for weakening bank lending standards quite makes sense", The Conversation, 13 October.

Dechezleprêtre, A. and M. Fadic (2021), "Can government venture capital help bring research to the market?", OECD Science, Technology and Innovation Policy Papers, forthcoming.

Deloitte (2019), Dynamics of the Australian Superannuation System: The Next 20 Years to 2038, Deloitte Actuaries and Consultants.

Deloitte (2018), Statutory Review of the Clean Energy Finance Corporation, Report prepared for the Department of the Environment and Energy.

Demmou, L., S. Calligaris, G. Franco, D. Dlugosch, M. Adalet McGowan and S. Sakha (2021), "Insolvency and debt overhang following the COVID-19 outbreak: Assessment of risks and policy responses", OECD Economics Department Working Papers, No. 1651, OECD Publishing, Paris.

Demmou, L., I. Stefanescu and A. Arquie (2019), "Productivity growth and finance: The role of intangible assets - a sector level analysis", OECD Economics Department Working Papers, No. 1547, OECD Publishing, Paris.

Department of the Treasury (2018), Regulation Impact Statement - Australian Business Securitisation Fund.

Dwyer, B. and B. Kotey (2015), "Financing SME Growth: The Role of the National Stock Exchange of Australia and Business Advisors", Australian Accounting Review, Vol. 25/2.

East and Partners (2021), SME Banking Insights 2021.

Farrell, S. (2020), Inquiry into Future Directions for the Consumer Data Right, Commonwealth of Australia, Canberra.

FIN-FSA (2020), "Report on means to prevent excessive household indebtedness", 6 May 2020.

Garner, M. and A. Suthakar (2021), "Developments in banks' funding costs and lending rates", RBA Bulletin, March.

Gocher, D. and ACCR staff (2021), Cutting Carbon; What the Rush to Divest Fossil Fuels Means for Emissions Reduction and Engagement, Australasian Centre for Corporate Responsibility.

Hall, B. and J. Lerner (2010), "The financing of R\&D and innovation”, Handbook of Economics, Vol. 1, pp 609-639.

Hayne, K. (2019), Royal Commission into Misconduct in the Banking, Superannuation and Financial 
Services Industry, Final Report, Volume 1, Commonwealth of Australia, Canberra.

Heil, M. (2017), "Finance and productivity: A literature review", OECD Economics Department Working Papers, No. 1374, OECD Publishing, Paris.

Henry, K. (2009), Australia's Future Tax System, Report to the Treasurer, Part 1.

Herd, E., M. McAdam, B. Bacani, S. O'Connor and E. Usher (2018), "Joint statement in support of a sustainable financial system for Australia and New Zealand", UNEPFI.

Hsu, P.-H., X. Tian, and Y. Xu (2014), "Financial development and innovation: cross-country evidence", Journal of Financial Economics, Vol. 112/1.

Hutley, N. and S.H. Davis (2021), "Climate change and directors' duties", Further supplementary memorandum of opinion, The Centre for Policy Development, 23 April.

Hutley, N. and S.H. Davis (2019), "Climate change and directors' duties", Supplementary memorandum of opinion, The Centre for Policy Development, 26 March.

Hutley N.C. and J.E. Mack (2021), "Superannuation trustee duties and climate change", Memorandum of opinion, The Centre for Policy Development, 16 February.

IGCC (Investor Group on Climate Change) (2020), Mapping Australia's Net Zero Investment Potential, IGCC Policy Update, October.

IMF (2020a), Global Financial Stability Report: Bridge to Recovery, International Monetary Fund, Washington DC.

IMF (2020b), Australia: Selected Issues, IMF Country Report No. 20/69, International Monetary Fund, Washington DC.

IMF (2019), Australia: Financial System Stability Assessment, IMF Country Report No. 19/54, International Monetary Fund, Washington DC.

Kaiser, T. et al. (2020), "Financial education affects financial knowledge and downstream behaviours", NBER Working Papers, No. 27057.

Kearns, J. (2020), "Banking and the COVID-19 Pandemic", Speech to UNSW's 33rd Australasian Finance and Banking Conference, 15 December.

Kent, C. (2021), "Small Businesses Finance in the Pandemic", Address to the Australian Finance Industry Association, 17 March.

KPMG (2020), Towards Net Zero: Australian Supplement.

Koreen, M., A. Laboul and N. Smaini (2018), "G20/OECD effective approaches for implementing the G20/OECD high-level principles on SME financing”, OECD SME and Entrepreneurship Papers, No. 9, OECD Publishing, Paris.

Kraemer-Eis, H., S. Signore, and D. Prencipe (2016), "The European venture capital landscape: an EIF perspective”, EIF Working Papers, No. 2016/34, European Investment Fund, Luxembourg.

Lumpkin, S. and S. Schich (2020), "Banks, Digital Banking Initiatives and the Financial Safety Net: Theory and Analytical Framework", Journal of Economic Science Research, Vol. 3/1,

Lusardi A. and O. Mitchell (2014), "The Economic Importance of Financial Literacy: Theory and Evidence", Journal of Economic Literature, vol. 52, no. 1, pp. 5-44.

Lusardi, A., and P. Tufano, (2015). "Debt Literacy, Financial Experiences, and Over Indebtedness," Journal of Pension Economics and Finance, Vol. 14/4, pp. 332-328.

Market Forces (2021), Out of Line, Out of Time, www.marketforces.org.au/campaigns/super/outofline/

Market Forces (2020), Funding Climate Failure: How Australia's Big Banks are Undermining the Paris Agreement, www.marketforces.org.au/campaigns/banks-new/bigfourscorecard/

Mian, A., A. Sufi and E. Verner (2015), "Household debt and business cycles worldwide", NBER Working Papers, No 21581. 
Morningstar (2020), Global Investor Experience Study: Disclosure, Morningstar.

MSCI (2021), MSCI Index Carbon Footprint Metrics, (accessed 14 May 2021).

Murray, G. (2021), "Ten meditations on government venture capital", Venture Capital, April 2021.

Murray, D., K. Davis, C. Dunn, C. Hewson, B. McNamee (2014), Financial System Inquiry - Final Report, Commonwealth of Australia, Canberra.

Nassr, I.K. and G. Wehinger (2014), "Non-bank debt financing for SMEs: The role of securitisation, private placements and bonds", OECD Journal: Financial Market Trends, Vol. 2014/1.

Nassr, I.K. and G. Wehinger (2016), "Opportunities and limitations of public equity markets for SMEs", OECD Journal: Financial Market Trends, Vol. 2015/1.

OAG (2016), Report 1 - Venture Capital Plan, 2016 Spring Reports of the Auditor General of Canada, Office of the Auditor-General of Canada.

OBIE (2020), "Adapting to survive: UK's small businesses leverage open banking as part of their COVID19 crisis recovery", Open Banking Implementation Entity, 7 December.

OECD (2021a), Brick by Brick: Building Better Housing Policies, OECD Publishing, Paris.

OECD (2021b), Financial Markets and Climate Transition, forthcoming.

OECD (2021c), Digital delivery of financial education: design and practice. www.oecd.org//financial/education/digital-delivery-of-financial-education-design-and-practice.htm

OECD (2020a), Digital Disruption in Banking and its Impact on Competition, 26 February 2020.

OECD (2020b), Corporate and Personal Insolvency During the COVID-19 Crisis, OECD Publishing Paris.

OECD (2020c), OECD Economic Surveys: Costa Rica 2020, OECD Publishing, Paris, https://doi.org/10.1787/2e0fea6c-en.

OECD (2020d), Financing SMEs and Entrepreneurs 2020: An OECD Scoreboard, OECD Publishing, Paris.

OECD (2020e), "Open banking", Chapter 2 in Financial Markets, Insurance and Pensions: Digital Technologies and Finance.

OECD (2020f), OECD Business and Finance Outlook 2020: Sustainable and Resilient Finance, OECD Publishing, Paris.

OECD (2020g), Financial Consumer Protection Policy Approaches in the Digital Age: Protecting Consumers' Assets, Data and Privacy, OECD Publishing, Paris.

OECD (2020h), Advancing the Digital Financial Inclusion of Youth, Report prepared for the G20 Global Partnership for Financial Inclusion by the OECD.

OECD (2020i), PISA 2018 Results (Volume IV): Are Students Smart about Money?, PISA, OECD Publishing, Paris.

OECD (2020j), Personal Data Use in Financial Services and the Role of Financial Education: A Consumer-Centric Analysis, www.oecd.org/daf/fin/financial-education/Personal-Data-Use-inFinancial-Services-andthe-Role-of-Financial-Education.pdf

OECD (2019a), "Access to finance", in OECD SME and Entrepreneurship Outlook 2019, OECD Publishing, Paris.

OECD (2019b), OECD Environmental Performance Reviews: Australia 2019, OECD Environmental Performance Reviews, OECD Publishing, Paris.

OECD (2019c) "Short-term consumer credit and inclusiveness", Chapter 4 in Financial Markets Insurance and Pensions: Inclusiveness and Finance, OECD Publishing, Paris.

OECD (2019d), Policy Handbook on Financial Education for Young People in the Commonwealth of Independent States, OECD Publishing, Paris. 
OECD (2019e), Linking Indigenous Communities with Regional Development, OECD Rural Policy Reviews, OECD Publishing, Paris.

OECD (2018a), OECD Economic Surveys: Australia 2018, OECD Economic Surveys, OECD Publishing, Paris.

OECD (2018b), Financing SMEs and Entrepreneurs 2018: An OECD Scoreboard, OECD Publishing, Paris.

OECD (2018c), Flexibility and Proportionality in Corporate Governance, Corporate Governance, OECD Publishing, Paris.

OECD (2018d), G20/OECD Policy Guidance on Financial Consumer Protection Approaches in the Digital Age, https://www.oecd.org/finance/G20-OECD-Policy-Guidance-Financial-Consumer-ProtectionDigital-Age-2018.pdf.

OECD (2018e), G20/OECD INFE Policy Guidance on Digitalisation and Financial Literacy, http://www.oecd.org/finance/G20-OECD-INFE-Policy-Guidance-Digitalisation-Financial-Literacy2018.pdf.

OECD (2017a), OECD Economic Surveys: Australia 2017, OECD Publishing, Paris.

OECD (2017b), Investing in Climate, Investing in Growth, OECD Publishing, Paris

OECD (2015a), New Approaches to SME and Entrepreneurship Financing: Broadening the Range of Instruments, OECD Publishing, Paris.

OECD (2015b), National Strategies for Financial Education: OECD/INFE Policy Handbook, OECD Publishing, Paris.

Pavlova, E. and S. Signore (2019), "The European venture capital landscape: an EIF perspective", EIF Working Papers, No. 2019/55, European Investment Fund, Luxembourg.

PC (Productivity Commission) (2018), Competition in the Australian Financial System, Productivity Commission Inquiry Report No. 89, Canberra.

PC (2015), Business Set-up, Transfer and Closure, Productivity Commission Inquiry Report No. 75, Canberra.

Phillips, B. and V. Narayanan (2021), Financial Stress and Social Security Settings in Australia, ANU Centre for Social Research Methods, April.

PMC (Prime Minister and Cabinet) (2020), Applying Behavioural Insights to the Personal Property Securities Register, Advisory Report, Australian Government, Canberra.

Price, F., B. Beckers, and G. La Cava (2019), "The effect of mortgage debt on consumer spending: evidence from household-level data", RBA Research Discussion Paper, No. 2019-06, Reserve Bank of Australia, Sydney.

PRA (Prudential Regulation Authority) (2018), Annual Competition Report 2017, Bank of Englland, London.

RBA (2021), Financial Stability Review, Reserve Bank of Australia, April.

RBA (2020a), Financial Stability Review, Reserve Bank of Australia, October.

RBA (2020b), Financial Stability Review, Reserve Bank of Australia, April.

RBA (2015), Submission to the Inquiry into Home Ownership, Reserve Bank of Australia.

Royal Commission into National Natural Disaster Arrangements (2020), Report, Commonwealth of Australia, 28 October 2020.

Russell, R., J. Kutin and T. Marriner (2020), Financial Capability Research in Australia, RMIT University, Melbourne.

SDTA (Stop the Debt Trap Alliance) (2021), Submission: National Consumer Credit Protection Amendment (Supporting Economic Recovery) Bill 2020, No. 55, 2 February. 
SDTA (2019), The Debt Trap: How Payday Lending is Costing Australians, Consumer Action Law Centre, Melbourne.

Select Committee on Financial Technology and Regulatory Technology (2020), Interim report, Commonwealth of Australia, Canberra.

Select Committee on Financial Technology and Regulatory Technology (2021), Second interim report, Commonwealth of Australia, Canberra.

Summerhayes, G. (2020), Speech to Australian Business Roundtable for Disaster Resilience and Safer Communities webinar, 14 October.

Sylvan, L. (2019), The Countervailing Power: Review of the Coordination and Funding for Financial Counselling Services Across Australia.

Wagland, S. and S. Taylor (2015), "The conflict between financial decision making and indigenous Australian culture", Financial Planning Research Journal, Vol. 1/1.

Weier, M., K. Dolan, A. Powell, K. Muir and A. Young (2019), Money Stories: Financial Resilience among Aboriginal and Torres Strait Islander Australians 2019, Centre for Social Impact and UNSW Sydney, Sydney.

Weild, D., E. Kim and L. Newport (2013), "Making Stock Markets Work to Support Economic Growth: Implications for Governments, Regulators, Stock Exchanges, Corporate Issuers and their Investors", OECD Corporate Governance Working Papers, No. 10, OECD Publishing, Paris.

Whittaker, B. (2015), Review of the Personal Property Securities Act 2009, Final Report, Commonwealth of Australia, Canberra.

Wilkins, R. (2020), "Household wealth", Chapter 10 in R. Wilkins et al. (2020), The Household, Income and Labour Dynamics in Australia Survey: Selected Findings from Waves 1 to 18, Melbourne Institute: Applied Economic \& Social Research, Melbourne.

Wolfrom, L. and M. Yokoi-Arai (2016), "Financial instruments for managing disaster risks related to climate change", OECD Journal: Financial Market Trends, vol. 2015/1, OECD Publishing, Paris.

World Bank (2019), Credit Reporting Knowledge Guide, The World Bank Group, Washington DC. 


\section{Annex A. The Royal Commission into misconduct in the financial services industry}

On 30 November 2017 the Prime Minister and Treasurer announced a Royal Commission into Misconduct in the Banking, Superannuation and Financial Services Industry. An interim report was handed down in September 2018 and the final report was released in February 2019.

The final report contained 76 recommendations under the themes:

- Banking (17 recommendations)

- Financial advice (10 recommendations)

- Superannuation (9 recommendations)

- Insurance (15 recommendations)

- Culture, governance and remuneration (7 recommendations)

- Regulators (14 recommendations)

- Other important steps (i.e. external dispute resolution, follow-up to the ASIC Enforcement Review Taskforce, and simplification; 4 recommendations)

In parallel to the Royal Commission, the Senate Economics References Committee undertook an inquiry into credit and financial products targeted at Australians at risk of financial hardship to assess some products and providers outside the scope of the royal commission. The final report of the Senate Committee inquiry made 20 recommendations including coverage of the regulatory framework, funding of various support services, and expanding affordable credit options.

\section{Annex Table A.1. Recommendations from the royal commission relating to the banking sector}

\begin{tabular}{|c|c|}
\hline Recommendation & Status \\
\hline $\begin{array}{l}\text { The National Consumer Credit Protection Act should not be amended to alter } \\
\text { the obligation to assess unsuitability. }\end{array}$ & $\begin{array}{l}\text { Legislation to repeal responsible lending obligations for } \\
\text { most credit products is with the Parliament. ASIC will } \\
\text { apply elements of APRA's bank lending standards to non- } \\
\text { banks. Lenders may rely on information provided by } \\
\text { borrowers (replacing a "lender beware" principle). }\end{array}$ \\
\hline $\begin{array}{l}\text { Best interests duty: the law should be amended to provide that, when acting in } \\
\text { connection with home lending, mortgage brokers must act in the best interests } \\
\text { of the intending borrower, with a civil penalty provision. }\end{array}$ & $\begin{array}{l}\text { From } 1 \text { January } 2021 \text { the Act provides that mortgage } \\
\text { brokers must act in the best interests of consumers when } \\
\text { providing credit assistance in relation to credit contracts. }\end{array}$ \\
\hline $\begin{array}{l}\text { Mortgage broker remuneration: The borrower, not the lender, should pay the } \\
\text { mortgage broker a fee for acting in connection with home lending. } \\
\text { Changes in brokers' remuneration should be made over a period of two or three } \\
\text { years, by first prohibiting lenders from paying trail commission to mortgage } \\
\text { brokers in respect of new loans, then prohibiting lenders from paying other } \\
\text { commissions to mortgage brokers. }\end{array}$ & $\begin{array}{l}\text { The Government agreed to address conflicted } \\
\text { remuneration for brokers. From } 1 \text { January } 2021 \text { some } \\
\text { types of conflicted remuneration are banned. }\end{array}$ \\
\hline $\begin{array}{l}\text { A Treasury-led working group should be established to monitor and, if } \\
\text { necessary, adjust the remuneration model [for mortgage brokers], and any fee } \\
\text { that lenders should be required to charge to achieve a level playing field, in } \\
\text { response to market changes. }\end{array}$ & $\begin{array}{l}\text { In } 2022 \text { the Council of Financial Regulators and ACCC } \\
\text { will conduct a review of the impact of changes to } \\
\text { remuneration. }\end{array}$ \\
\hline $\begin{array}{l}\text { Mortgage brokers as financial advisers: after a sufficient period of transition, } \\
\text { mortgage brokers should be subject to and regulated by the law that applies to } \\
\text { entities providing financial product advice to retail clients. }\end{array}$ & No change as yet. \\
\hline $\begin{array}{l}\text { Australian Credit Licence holders should: } \\
\text { be bound by information-sharing and reporting obligations in respect } \\
\text { of mortgage brokers similar to those referred to in [the Report's } \\
\text { recommendations] for financial advisers; and }\end{array}$ & Legislation has passed Parliament. \\
\hline
\end{tabular}


- take the same steps in response to detecting misconduct of a mortgage broker as those referred to in [the recommendation] for financial advisers.

Point-of-sale exemption for retail dealers from the operation of the National Consumer Credit Protection Act should be abolished.

The ABA should amend the Banking Code to provide that:

- banks will work with customers:

- who live in remote areas; or

- $\quad$ who are not adept in using English

to identify a suitable way for those customers to access and undertake their banking;

- if a customer is having difficulty proving his or her identity, and tells the bank that he or she identifies as an Aboriginal or Torres Strait Islander person, the bank will follow AUSTRAC's guidance about the identification and verification of persons of Aboriginal or Torres Strait Islander heritage;

- $\quad$ without prior express agreement with the customer, banks will not allow informal overdrafts on basic accounts; and

- banks will not charge dishonour fees on basic accounts.

The NCCP Act should not be amended to extend its operation to lending to small businesses.

The ABA should amend the definition of 'small business' in the Banking Code so that the Code applies to any business or group employing fewer than 100 fulltime equivalent employees, where the loan applied for is less than AUD5 million. A national scheme of farm debt mediation should be enacted.

Valuations of land: APRA should amend Prudential Standard APS 220 to:

- require that internal appraisals of the value of land taken or to be taken as security should be independent of loan origination, loan processing and loan decision processes; and

- provide for valuation of agricultural land in a manner that will recognise, to the extent possible:

- $\quad$ the likelihood of external events affecting its realisable value; and

- $\quad$ the time that may be taken to realise the land at a reasonable price affecting its realisable value.

The ABA should amend the Banking Code to provide that, while a declaration remains in force, banks will not charge default interest on loans secured by agricultural land in an area declared to be affected by drought or other natural disaster.

When dealing with distressed agricultural loans, banks should:

- ensure that those loans are managed by experienced agricultural bankers;

- offer farm debt mediation as soon as a loan is classified as distressed;

- manage every distressed loan on the footing that working out will be the best outcome for bank and borrower, and enforcement the worst;

- recognise that appointment of receivers or any other form of external administrator is a remedy of last resort; and

- cease charging default interest when there is no realistic prospect of recovering the amount charged.

Enforceable code provisions: The law should be amended to provide:

- that ASIC's power to approve codes of conduct extends to codes relating to all APRA-regulated institutions and ACL holders;

- that industry codes of conduct approved by ASIC may include 'enforceable code provisions', which are provisions in respect of which a contravention will constitute a breach of the law;

- that ASIC may take into consideration whether particular provisions of an industry code of conduct have been designated as 'enforceable code provisions' in determining whether to approve a code;
No change. In its official response the government agreed with the change.

In December 2019 the Banking Code was amended to:

- $\quad$ provide inclusive and accessible banking services to those with limited English and those living in remote areas

- $\quad$ give concession card holders access to accounts with no overdraft and dishonour fees

- $\quad$ make features of a basic, low and no fee bank account for low-income earners uniform across the industry.

No change (as recommended).

In progress. The loan threshold will be increased to AUD 5 million following the completion of the current review of the Banking Code.

In progress. The federal government is relying on states to change legislation. Tasmania introduced a scheme in January 2021.

Implementation of the new standard was delayed to 1 January 2022 due to COVID-19.

The Banking Code of Practice was changed in December 2019.

The Banking Code of Practice now bans charging default interest on distressed agricultural loans.

Legislation passed Parliament in December 2020 
- for remedies, modelled on those now set out in Part VI of the Competition and Consumer Act, for breach of an 'enforceable code provision'; and

- for the establishment and imposition of mandatory financial services industry codes.

In respect of the Banking Code that ASIC approved in 2018, the ABA and ASIC should take all necessary steps to have the provisions that govern the terms of the contract made or to be made between the bank and the customer or guarantor designated as 'enforceable code provisions'.

BEAR product responsibility: After appropriate consultation, APRA should determine for the purposes of section 37BA(2)(b) of the Banking Act, a responsibility, within each $A D I$ subject to the BEAR, for all steps in the design, delivery and maintenance of all products offered to customers by the ADI and

In progress. Legislation passed Parliament in December 2020 and $A B A$ and $A S I C$ will now consider inclusion in the Banking Code.

Exposure Draft legislation to enable rules to be made to implement recommendation was released on 16 July 2021. any necessary remediation of customers in respect of any of those products.

Source: Hayne, K. (2019), Royal Commission into Misconduct in the Banking, Superannuation and Financial Services Industry; Australian Government (2019), Restoring Trust in Government; Australian Banking Association; The Guardian (2021), "Banking royal commission: most recommendations have been abandoned or delayed" 19 Jan; ABC (2021), "Banking royal commission recommendations flounder, two years on", 4 February. 